\title{
Ground Improvement Techniques for Liquefaction Remediation Near Existing Lifelines
}

Ronald D. Andrus

Riley M. Chung

October 1995

Building and Fire Research Laboratory

National Institute of Standards and Technology

Gaithersburg, MD 20899

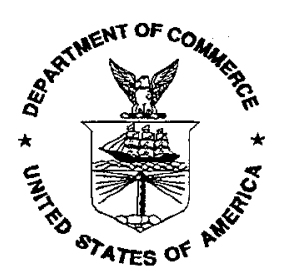

U.S. Department of Commerce

Ronald H. Brown, Secretary

Technology Administration

Mary L. Good, Under Secretary for Technology

National Institute of Standards and Technology

Arati Prabhakar, Director 


\begin{abstract}
This report reviews five low vibration ground improvement techniques suitable for remedial work near existing structures. The five techniques are: compaction grouting, permeation grouting, jet grouting, in situ soil mixing, and drain pile. The factors which can influence the effectiveness of each technique are identified. Cost estimates are given for each technique, except the drain pile technique which is not yet available in the United States. Nineteen case studies of liquefaction remediation and remedial work near existing lifelines are reviewed. Advantages and constraints of the five techniques are compared. A combination of techniques may provide the most cost-effective ground improvement solution for preventing damage to existing lifelines resulting from liquefaction-induced horizontal ground displacement, subsidence, and uplift.
\end{abstract}

KEYWORDS: building technology; compaction grouting; cost estimate; drain pile; earthquake; ground improvement; jet grouting; lifelines; liquefaction remediation; permanent ground deformation; permeation grouting; soil liquefaction; soil mixing. 


\section{ACKNOWLEDGMENTS}

Joseph Welsh, George Burke, and Juan Baez of Hayward Baker Inc. kindly provided technical information on ground improvement. Special thanks are given to the Divisional reader Dat Duthinh, and to the outside reviewer Steven Glaser of the Colorado School of Mines. 


\section{CHAPTER 1}

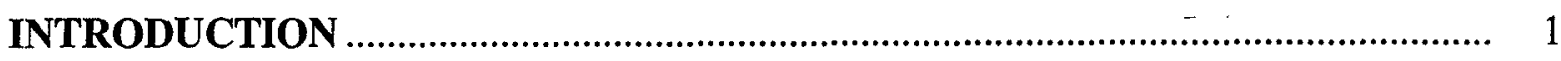

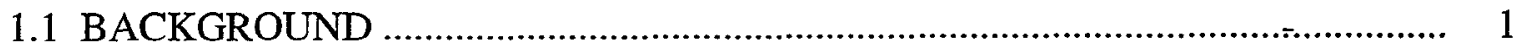

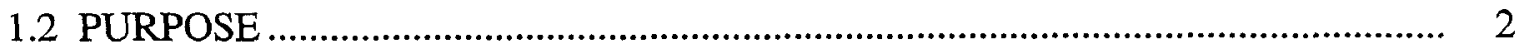

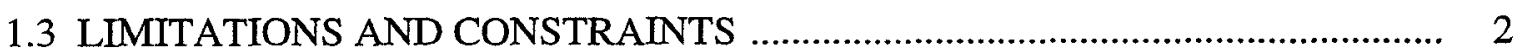

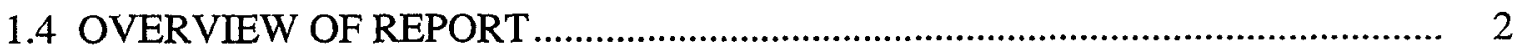

\section{CHAPTER 2}

\section{LOW VIBRATION GROUND IMPROVEMENT TECHNIQUES FOR}

LIQUEFACTION REMEDIATION ............................................................................ 3

2.1 INTRODUCTION ................................................................................

2.2 COMPACTION GROUTING ..................................................................... 4

2.2 .1 General .............................................................................................. 4

2.2.2 Liquefaction Remediation .............................................................................. 6

2.2.2.1 Pinopolis West Dam, South Carolina …………….............................. 6

2.2.2.2 Kings Bay Naval Submarine Base, Georgia .................................... 8

2.2.2.3 Steel Creek Dam, South Carolina ...................................................... 8

2.2.2.4 Fontvieille Zone D, Monaco .............................................................. 9

2.2.2.5 Kaiser Hospital Addition, San Francisco ............................................. 9

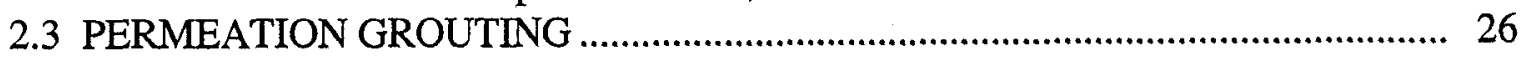

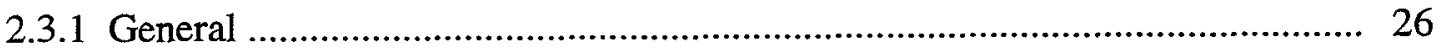

2.3.2 Liquefaction Remediation ...................................................................... 28

2.3.2.1 Riverside Avenue Bridge, Santa Cruz ........................................... 28

2.3.2.2 Roosevelt Junior High School, San Francisco ................................... 28

2.3.2.3 Supermarket at 4041 Geary Street, San Francisco ............................ 29

2.4 JET GROUTING ………………............................................................... 32

2.4.1 General ............................................................................................ 32

2.4.2 Liquefaction Remediation ............................................................................. 34

2.4.2.1 Transit Station, Taiwan ................................................................... 34

2.5 IN SITU SOIL MIXING .................................................................................... 40

2.5.1 General ....................................................................................... 40

2.5.2 Liquefaction Remediation ............................................................................... 42

2.5.2.1 Jackson Lake Dam, Wyoming ....................................................... 42

2.5.2.2 Pulp and Paper Mill Spill Tanks, British Columbia .......................... 43

2.5.2.3 Office Building ("Building N"), Japan .............................................. 44

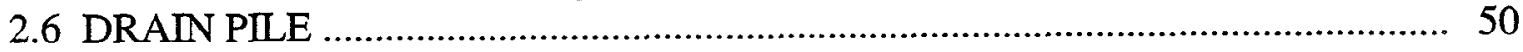

2.6 .1 General ............................................................................................. 50

2.6.2 Liquefaction Remediation ....................................................................... 52

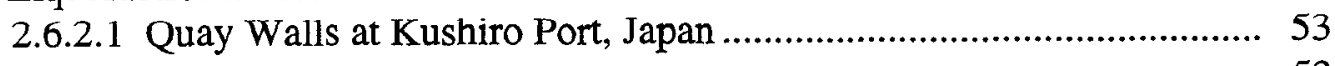

2.7 SUMMARY 


\section{CHAPTER 3}

3.2 PIPELINES AND CONDUITS ……............................................................. 59

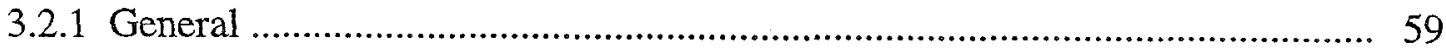

3.2.2 Case Studies of Ground Improvement Near Pipelines and Conduits .............. 60

3.2.2.1 Containment Wall at Utility Crossings, Michigan ............................ 60

3.2.2.2 Settled Pipes at Waste Water Treatment Plant ................................ 61

3.2.3 Liquefaction Remediation .................................................................... 61

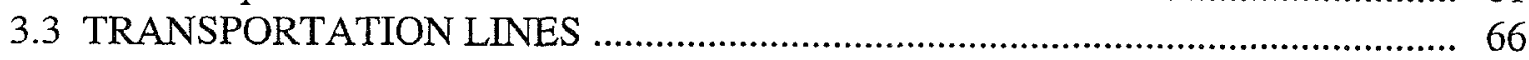

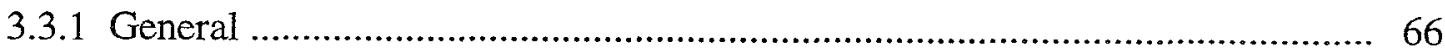

3.3.2 Case Studies of Ground Improvement Near Transportation Lines .................. 66

3.3.2.1 Highway Viaduct, San Diego .......................................................... 66

3.3.2.2 Settled Railroad Embankment, Georgia .......................................... 67

3.3.2.3 Tunnel Construction Beneath Rail Line, Switzerland ....................... 67

3.3.2.4 Tunnel Construction Beneath Airport Runway, Japan ........................ 68

3.4 SUMMARY

\section{CHAPTER 4}

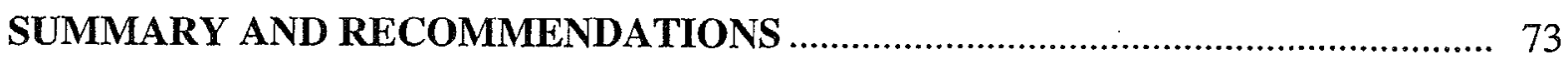

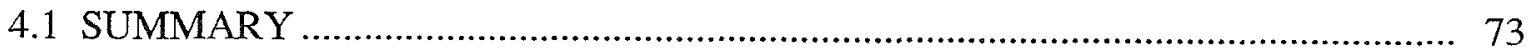

4.2 RECOMMENDATIONS FOR FUTURE STUDY ………................................... 73

APPENDIX A 


\section{CHAPTER 1}

\section{INTRODUCTION}

\subsection{BACKGROUND}

Lifeline systems have been broadly defined (Applied Technology Council, 1991) as "those systems necessary for human life and urban function, without which large urban regions cannot function." They include electric power, gas and liquid fuels, water and sewage, telecommunication and transportation systems.

One of the major factors of lifeline damage in earthquakes is horizontal ground displacement caused by liquefaction of loose granular soils, as illustrated in the case studies for many past earthquakes in the United States and Japan (O'Rourke and Hamada, 1992; Hamada and O'Rourke, 1992). Other important factors of lifeline damage caused by liquefaction of granular soils include local subsidence associated with densification of the soil and ejection of the water and soil, and flotation of buried structures that have a unit weight less than the unit weight of the surrounding liquefied soil. For example, horizontal ground displacement damaged many pipelines, bridges, roads, and buildings during the 1906 San Francisco, California, earthquake. Broken water lines made fighting fires after the earthquake impossible, and much of San Francisco burned. During the 1989 Loma Prieta earthquake, liquefaction, horizontal ground movement, major pipeline damage, and fires occurred at virtually the same locations in San Francisco. Of the 160 breaks in the Municipal Water Supply System of San Francisco in 1989, 123 were in the Marina where significant liquefaction and ground deformation had occurred (O'Rourke and Pease, 1992). Most recently, soil liquefaction during the January 17, 1995 Hanshin-Awaji (Kobe), Japan, earthquake completely destroyed Kobe port, which is primarily made of three man-made islands. Soil liquefaction caused numerous breaks in Kobe City and its surrounding area's water and gas supply systems, resulting in a number of fires and the total loss of water supply for fighting fires and for domestic use. Many transportation systems were also disrupted as the result of liquefaction (Chung et al., 1995).

Many lifeline structures lie in regions of high liquefaction and ground displacement potential. While it may be feasible to relocate some support facilities on sites which are not susceptible, similar precautions are not always possible for the long linear element of lifeline systems such as pipelines, electrical transmission lines, communication lines, highways, and rail lines. For some pipe systems, such as gas lines, it may be economical to replace old pipes with modern welded steel pipes that have less chance to break or leak, even after moderate deformation (O'Rourke and Palmer, 1994). For other pipe systems, such as water and sewage lines, the segmented pipe used can accommodate very little deformation. Ground improvement may be the most economical solution for these types of systems, and for all types of systems in areas where large ground displacement is anticipated. 


\subsection{PURPOSE}

Although several ground improvement techniques have been developed to varying degrees and used for liquefaction remediation on a number of projects involving existing structures, the approaches that have been developed are scattered in the literature. The purpose of this report is to present the state-of-practice of ground improvement for liquefaction remediation near existing structures. In particular, the long linear element of-lifeline systems supported by ground having high potential for liquefaction and horizontal ground displacement. It is hoped that this document will 1) aid the owners and designers in the planning of ground improvement for liquefaction remediation near existing lifelines, and 2) identify those areas where more study is needed.

\subsection{LIMITATIONS AND CONSTRAINTS}

Many of the case studies available in the literature do not cover all aspects of the project, rather they emphasize one or two aspects. For example, a case study may focus on ground improvement methodology, giving little information on seismic evaluation. In some cases, even key information on ground improvement methodology is lacking.

Because of the variable nature of soils and techniques, ground improvement is more art than engineering, based on experience, semi-empirical relationships, and site trials. For detailed design, construction and evaluation procedures, it is highly recommended that the reader consult relevant papers and reports, and experts in the fields of ground improvement, seismic evaluation, and lifeline earthquake engineering.

\subsection{OVERVIEW OF REPORT}

Following this introduction, in Chapter 2, five low vibration ground improvement techniques are identified, and available case studies of liquefaction remediation are reviewed. The application of these five techniques for remedial work near various lifelines is discussed in Chapter 3. Chapter 4 provides a summary of this report as well as brief remarks about additional needed research. 


\title{
CHAPTER 2
}

\section{LOW VIBRATION GROUND IMPROVEMENT TECHNIQUES}

\author{
FOR LIQUEFACTION REMEDIATION
}

\subsection{INTRODUCTION}

The risk of liquefaction and ground deformation can be reduced by the following types of ground improvement: densification, solidification, drainage, dewatering, and reinforcement (Ledbetter, 1985; National Research Council, 1985; Kramer and Holtz, 1991; JSSFME, 1995). Soil densification is generally considered highly reliable, and the standard remedial measure against liquefaction. It reduces the void space of the soil, thereby decreasing the potential for volumetric change that would lead to liquefaction. Resistance to shear deformation also increases with increased density. Several sites improved by densification performed well during the 1964 Niigata, Japan, 1978 Miyagiken-oki, Japan, 1989 Loma Prieta, California, and 1994 Northridge, California, earthquakes (Watanabe, 1966; Ishihara et al., 1980; Mitchell and Wentz, 1991; Graf, 1992a; Hayden and Baez, 1994). In one early report (Matso, 1995) from Kobe City, Japan, a site which had been treated by densification performed better than the surrounding untreated areas during the 1995 Hanshin-Awaji earthquake.

Solidification is also considered a highly reliable remedial measure against liquefaction. It prevents soil particle movement and provides cohesive strength. During the 1989 Loma Prieta earthquake, the few sites improved by solidification techniques performed well (Mitchell and Wentz, 1991; Graf, 1992a).

While the drainage method has been used for a number of liquefaction remediation projects in Japan, it has found limited use in the United States. Shake table tests (Sasaki and Taniguchi, 1982) indicate that gravel drains can accelerate the dissipation of excess pore water pressures, thereby limiting the loss of shear strength and reducing the uplift pressures acting on buried structures. Following the 1993 Kushiro-Oki, Japan, earthquake, Iai et al. (1994a, 1994b) observed that quay walls having back fill treated by the gravel drain pile and sand compaction pile techniques suffered no damage, while quay walls having untreated backfill were severely damaged due to liquefaction.

Lowering the ground water level by dewatering reduces the degree of saturation, thereby preventing the development of excess pore water pressure which would lead to liquefaction. Dewatering is a difficult and very expensive task, since both upstream and downstream seepage cutoffs are usually required, and pumps must be maintained constantly. 
Soil reinforcement provides resistance to ground deformation. Shake table tests (Yasuda et al., 1992) indicate that continuous underground walls can control horizontal ground movement. Their effectiveness depends on such factors as quantity, orientation, shear resistance, and excitation direction.

The most commonly used ground improvement techniques for liquefaction remediation at new construction sites are vibro-compaction, vibro-replacement, dynamic compaction, and sand compaction pile (Hayden and Baez, 1994; JSSFME, 1995). These four techniques improve the ground primarily by densification, and are typically less expensive than other techniques. However, they can produce objectionable levels of work vibration.

Techniques selected to improve the ground surrounding or adjacent to existing lifelines should be those that would not cause excessive level of disturbance to the lifelines. One densification technique that produces low levels of vibration during installation is compaction grouting, discussed in Section 2.2. Three low vibration techniques that improve primarily by solidification are permeation grouting, jet grouting, and in situ soil mixing. Permeation grouting is discussed in Section 2.3. Jet grouting and in situ soil mixing, discussed in Sections 2.4 and 2.5, can be highly cost-effective when used for reinforcement, or for cutoff walls to reduce seepage during dewatering. The dewatering alternative is not considered because the construction of cutoff walls and dewatering wells, and pump maintenance seem more expensive than the other alternatives. In Section 2.6, low vibration systems for installing drain piles are discussed.

\subsection{COMPACTION GROUTING}

\subsubsection{General}

Compaction grouting is the injection of a thick, low mobility grout that remains in a homogenous mass without entering soil pores. As the grout mass expands, the surrounding soil is displaced and densified. A conceptual drawing of compaction grouting is shown in Fig. 2.1. According to Rubright and Welsh (1993), development of the compaction grouting technique began in the United States during the early 1950s. It has been successfully used to correct structural settlement, prevent settlement during soft ground tunneling in urban areas, protect structures against local zones of sinkhole settlement, and densify liquefiable soil.

There are many factors which can influence the effectiveness of compaction grouting (Graf, 1992b; Warner et al., 1992; Rubright and Welsh, 1993) including:

1. Soil Being Compacted. Cohesive soils are harder to compact than cohesionless soils. The technique is not effective in thick, saturated clayey soils, and may be marginally effective in silt deposits. 
2. Earth Pressures. Overlying ground will heave if overburden pressure is low, and injection pressure and rate are too high.

3. Grout Mix. Recommended grout mixes consist of silty sand, cement, fly ash, and water. Grout slump is usually set at about $25 \mathrm{~mm}$. It has been recommended that the use of bentonite and other clay materials be restricted, since hydraulic fracturing and limited compaction will occur if grout contains sufficient clay irrespective of slump. Cement may not be needed for just soil densification.

4. Grout Injection Pressure and Rate. Excessive injection rates and pressures will result in premature heaving of overlying ground. The maximum pressure also depends on the sensitivity of adjacent structures.

5. Grout Injection Volume. Uneven distribution of grout will likely result in uneven improvement. Injection volumes range from as low as $4 \%$ of the treated volume to as high as $20 \%$ for sinkhole areas.

6. Grout Hole Spacing. Holes spaced too far apart will leave zones of undensified soil. For deep injection (greater than about $3 \mathrm{~m}$ ), final spacings of 2 to $4 \mathrm{~m}$ are frequently used. For shallow injection, final spacings usually range from 1 to $2 \mathrm{~m}$.

7. Injection Sequence. Effective sequencing will utilize confinement created in previous work. Grouting can be performed from the top down (stage down) or from the bottom up (stage up). While stage up grouting is generally more economical, stage down grouting utilizes confinement created in previous work. Near the ground surface where confining pressures are low, stage down grouting may be required to achieve specified compaction levels. It is considered good practice to have at least primary and secondary grout holes, where secondary holes split the distance between primary holes. Injection stages or increments of 0.3 to $0.9 \mathrm{~m}$ have been used. In addition, splitting the injection depths will also contribute to greater uniformity.

Rational design methods have been presented for compaction grouting to reduce settlement (Gambin, 1991) and to protect overlying construction against local zones of sinkhole settlement (Schmertmann and Henry, 1992).

According to Welsh (1995), the cost to mobilize and demobilize the compaction grouting equipment is between $\$ 8,000$ and $\$ 15,000$ per rig. To install $76-\mathrm{mm}$ diameter grout pipe, the cost starts at about $\$ 50$ per meter of pipe. This cost would double for low headroom work. The cost of injection labor and grout materials starts at about $\$ 20$ per cubic meter of improved soil, assuming the volume of grout injected is $10 \%$ of the total volume of treated soil. 


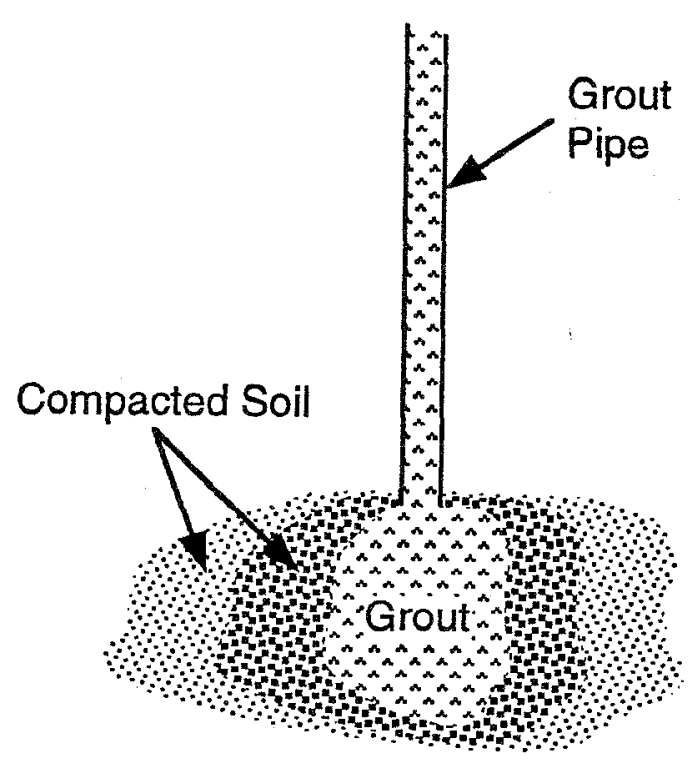

Fig. 2.1 - Conceptual Drawing of Soil Densification by Compaction Grouting.

\subsubsection{Liquefaction Remediation}

Several remediation projects where compaction grouting was used to densify liquefiable soils are summarized in Table 2.1. These projects can be separated into the following categories: 1) treatment beneath existing structures, 2) treatment in urban areas where low levels of vibration and noise were required, 3) treatment below thick zones not requiring improvement, and 4) treatment of small areas. Five case studies are reviewed in more detail as follows.

\subsubsection{Pinopolis West Dam, South Carolina}

The Pinopolis West Dam is a $21.3 \mathrm{~m}$ high and $2,011 \mathrm{~m}$ long earthfill dam near Moncks Corner, South Carolina. It was constructed in 1940 on a site underlain by a 1.2- to 2.4-m thick layer of very loose sand to silty sand. As reported by Salley et al. (1987), corrected blow count measured in the loose sand layer by the Standard Penetration Test (SPT) method ranged from 0 to 7 blows per $0.3 \mathrm{~m}$, with an average value of 4 . In-place dry unit weights ranged from 13 to $16 \mathrm{kN} / \mathrm{m}^{3}$, and void ratios ranged from 0.94 to 0.65 . It was determined that this sand layer could liquefy during the design earthquake, and a corrected blow count, $N_{1}$, of 11 would be sufficient to avoid liquefaction at the downstream toe of the dam. 
In 1984, a pilot study (Salley et al., 1987) was conducted to evaluate the feasibility of compaction grouting for compacting the loose sand. A typical cross section of the pilot study area at the downstream toe of the dam is shown in Fig. 2.2. The test pad shown in the center of Fig. 2.2 was constructed to provide sufficient confining pressure so that effective compaction could be achieved without causing excessive heave of the overlying materials. Six grain-size distribution curves for samples taken from the loose sand by a split-barrel sampler, $35 \mathrm{~mm}$ inside diameter, are presented in Fig. 2.3. Compaction grouting was initially performed on 3.7$\mathrm{m}$ grid pattern, with secondary and tertiary grout stages splitting the grid to $1.8 \mathrm{~m}$. A sandcement grout with a slump of about $76 \mathrm{~mm}$ was used. The grout was injected at a rate of 0.06 $\mathrm{m}^{3}$ per minute. Grouting continued at a location until a pre-determined amount of grout was injected or the pressure could not be kept below $2 \mathrm{MPa}$. At which time the grout pipe was raised $0.3 \mathrm{~m}$ and grout injection resumed. After the grouting program was completed, average $\mathrm{N}_{1}$-values measured at the midpoint between grout holes increased to 17 . Profiles of before and after average $\mathrm{N}_{1}$-values are shown in Fig. 2.4. Salley et al. suggest the decrease in $\mathrm{N}_{1}$ after tertiary grouting was due to random variations within the small statistical base. Tip resistances measured by the Cone Penetration Test (CPT) method increased from an average value of 2.3 to 7.9 MPa. Profiles of before and after average tip resistances are shown in Fig. 2.5. The improvement in penetration resistances for each grouting stage is summarized in Fig. 2.6. The modulus determined by the Dilatometer Test (DMT) increased from an average value of 10 to $66 \mathrm{MPa}$. The increase in penetration and modulus values demonstrated that compaction grouting successfully densified the loose sand.

The production grouting program (Baez and Henry, 1993) was conducted in 1989. Prior to production grouting, a berm was placed over the planned improvement area at the downstream toe to provide greater confinement and a working surface. The elevation of the berm was $1.3 \mathrm{~m}$ higher than the elevation of the test pad shown in Fig. 2.2. At each injection location, the grout pipe was installed to the bottom of the loose sand. Grout with slump less than $76 \mathrm{~mm}$ was pumped into the casing until a pre-determined amount of grout was injected or pressure at casing reached $2 \mathrm{MPa}$ or a certain amount of heave occurred. The maximum volume of injected grout was $1.12 \mathrm{~m}^{3}$ per meter in primary holes, $0.92 \mathrm{~m}^{3}$ per meter in secondary holes, and no maximum in tertiary holes. To ensure that the dam was not damaged, the maximum allowable heave was initially set at $19 \mathrm{~mm}$ measured at $1.8 \mathrm{~m}$ above the loose sand and $6 \mathrm{~mm}$ measured at the ground surface. These limits were later revised to $100 \mathrm{~mm}$ and $25 \mathrm{~mm}$, respectively. The flow rate was limited to $0.08 \mathrm{~m}^{3}$ per minute. When one of the above criteria was met, the pipe was raised $0.3 \mathrm{~m}$ and grout injection resumed. Primary injections were performed on $3.7-\mathrm{m}$ grid pattern, with secondary and tertiary injections splitting the grid to $1.8 \mathrm{~m}$. The equivalent scaled grout diameter at each injection location is illustrated in Fig. 2.7. Based on 182 grout locations, an average of $1.02 \mathrm{~m}^{3}$ per meter was injected at each primary location, $0.49 \mathrm{~m}^{3}$ per meter was injected at each secondary location, and $0.46 \mathrm{~m}^{3}$ per meter was injected at each tertiary location. Where $\mathrm{N}_{1}$-values after tertiary grouting were found to be below the required value of 12 to 17 (depending on the fines content), a quaternary injection phase was applied. At the completion of the grouting program, the ratio of injected grout volume to treated volume ranged between $14 \%$ and $21 \%$, with an average value of $18 \%$. The total area of treatment was $5,626 \mathrm{~m}^{2}$. Values of $\mathrm{N}_{1}$ after treatment ranged from 11 to 38 . Profiles of $\mathrm{N}_{1}$ determined before and after treatment are shown in Fig. 2.8. 


\subsubsection{Kings Bay Naval Submarine Base, Georgia}

The construction of various facilities was planned at the Kings Bay Submarine Base on soils ranging from fine sand to clayey sand with some thin clay and silt seams. The general range of grain-size distribution for the foundation soils is shown in Fig. 2.9. Below the depth of about $4 \mathrm{~m}$, SPT blow counts ranged from 1 to 40 , CPT tip resistances varied between 0.5 and $24 \mathrm{MPa}$, and DMT modulus values ranged from 2.4 to $96 \mathrm{MPa}$. It was believed that the looser zones could settle and liquefy as a result of seismic activity or exploding warheads. The vibrocompaction, vibro-replacement, dynamic compaction and compaction grouting techniques were used to densify loose foundation soils to a depth of $15 \mathrm{~m}$ (Hussin and Ali, 1987).

Compaction grouting was used to densify the loose sands that were overlain by materials not requiring improvement about $4 \mathrm{~m}$ thick (Hussin and $\mathrm{Ali}, 1987$ ). It was performed with two phases for a final injection spacing of $2.7 \mathrm{~m}$. As described by Hussin and Ali (1987), the procedure for each location began by inserting 100 -mm diameter grout pipe into the ground to the bottom of the soil needing treatment. Grout was then injected into the soil under pressures up to $7 \mathrm{MPa}$ as the pipe was withdrawn. The grout consisted of silty fine sand, cement, additives, and sufficient water for a slump of $51 \mathrm{~mm}$. The total area of treatment by compaction grouting was $20,848 \mathrm{~m}^{2}$. Profiles of CPT tip resistance, sleeve friction and friction ratio determined before and after compaction grouting are shown in Fig. 2.10. Most soils with low friction ratio (less than about $1 \%$ ) were improved to the target relative density, $\mathrm{D}_{\mathrm{r}}$, of $70 \%$, as shown in Fig. 2.10. The tip resistances of soils with high friction ratio were increased by as much as $100 \%$.

\subsubsection{Steel Creek Dam, South Carolina}

The Steel Creek Dam is a $27 \mathrm{~m}$ high and $670 \mathrm{~m}$ long earthfill dam located at the Savannah River Plant, South Carolina. The dam was completed in 1985. Construction included densification of loose foundation soil to prevent seismic-induced liquefaction below the embankment. As reported by Keller et al. (1987), the dam was designed to withstand a peak horizontal ground surface acceleration of $0.1 \mathrm{~g}$ caused by a magnitude 6.6 earthquake. The upper $15 \mathrm{~m}$ of foundation soil, shown in Fig. 2.11, was composed of clayey sand with $3 \%$ to $20 \%$ fines (silt and clay). A 6-m thick zone within the layer of clayey sand exhibited SPT blow counts less than 10; CPT tip resistances less than about $8 \mathrm{MPa}$; and shear wave velocities determined by the crosshole method of 120 to $140 \mathrm{~m} / \mathrm{s}$. Typical profiles of soil type, penetration, density and fines content are shown in Fig. 2.12. Pilot studies were conducted to evaluate the effectiveness of the dynamic compaction, stone column, compaction grouting and vibratory pile driving techniques in compacting the clayey sands. Compaction grouting was generally ineffective in compacting even the sands with $3 \%$ to $10 \%$ clayey fines. 


\subsubsection{Fontvieille Zone D, Monaco}

As reported by Gambin (1991), the Fontvieille area in the Principality of Monaco was reclaimed in the 1970 s by dumping sand with cobbles, gravel and silt from barges. A typical profile showing ground conditions after reclamation between the depths of 7 and $22 \mathrm{~m}$ is presented in Fig. 2.13. The dumped fill (designated as sand and gravel, and silty gravelly sand) extended to a depth of $15.5 \mathrm{~m}$, and was underlain by natural silty sand. Also shown in the figure are grain-size distribution curves for samples taken from the fill and silty sand layers. Since the area is prone to earthquake, it was necessary to densify these layers. The upper $7 \mathrm{~m}$ of fill was dynamically compacted. Temporary embankments up to $16 \mathrm{~m}$ high were constructed to preload and compact the deeper layers. This treatment was considered to be sufficient for housing structures.

In the early 1980 s, community facilities consisting of a church, a post office, a fire station, a police station, and a two-story parking garage were proposed. Field testing at the proposed site included standard penetration, seismic crosshole, and Ménard pressuremeter. In addition, various drilling parameters, such as penetration rate, thrust, and torque, were recorded. Results from the pressuremeter and a combined drilling parameter, $\beta$, were discussed by Gambin (1991). The uncompacted cobblely fill and the natural silty sand exhibited an average pressuremeter modulus, E, of 4 and $5 \mathrm{MPa}$, respectively. As shown in Profile A of Fig. 2.14, the Ménard E-modulus and $\beta$-parameter exhibited similar trends. Compaction grouting was considered the most appropriate ground improvement technique for the site. Without treatment, the settlement in critical zones would be on the order of $84 \mathrm{~mm}$. It was determined that an average E-modulus greater than $8 \mathrm{MPa}$ would decrease the foundation settlement in critical zones to about $16 \mathrm{~mm}$ and reduce the potential for liquefaction to an acceptable level. The shaded zone in Profile B of Fig. 2.14 expresses the critical zone.

In the non critical areas, mostly parking garage, grout was injected through primary and secondary holes located in a square grid pattern with final spacing equal to $3.6 \mathrm{~m}$. The ratio of injected grout to treated volume did not exceed $3.8 \%$. In the critical areas, office buildings and church, grout was injected through primary, secondary and tertiary holes in a square grid pattern with final spacing equal to $2.5 \mathrm{~m}$. The injected volume in the critical areas did not exceed 4.8\%. The after treatment $\beta$-parameter is shown in Profile $\mathrm{C}$ of Fig. 2.14. The average after treatment Ménard E-modulus ranged from 8 to $10 \mathrm{MPa}$. When the building was completed in 1987 the observed settlement was less than $10 \mathrm{~mm}$.

\subsubsection{Kaiser Hospital Addition, South San Francisco}

A single-story addition was planned for the Kaiser Hospital in South San Francisco, California, on a site underlain by a potentially liquefiable layer of hydraulically placed sand fill (Mitchell and Wentz, 1991; Graf, 1992a). The hydraulic sand fill was as much as $8 \mathrm{~m}$ thick, and overlain by $2.4 \mathrm{~m}$ of unconsolidated fill consisting of sand, gravel, clay, and construction 
debris. The ground water table was about $2 \mathrm{~m}$ below the ground surface. Average corrected SPT blow counts, N, measured before treatment in the hydraulic sand fill ranged from 15 to 26 . The liquefaction potential of the hydraulic fill was considered to be moderate during large earthquake shakings, with the minimum value of peak horizontal ground surface acceleration needed for liquefaction to occur equal to about $0.25 \mathrm{~g}$. Since noise from pile driving would have been too disruptive to hospital operation, compaction grouting was considered the most cost-effective solution.

In 1979 , a pilot study was conducted at the site to evaluate the effectiveness of compaction grouting. Grout pipes were installed to the top of the sand fill. A thick (slump less than $51 \mathrm{~mm}$ ), sand-cement grout was injected until a slight ground heave (about $3 \mathrm{~mm}$ ) was observed or the injection pressure reached $4 \mathrm{MPa}$. After the grout harden, the hole was advanced 0.9 to $1.2 \mathrm{~m}$ to the next injection point. Grout holes in the test section were spaced $2.4 \mathrm{~m}$ on center in a triangular grid pattern. The ratio of injected grout volume to treated soil volume was about $10 \%$. SPTs and CPTs were performed to evaluate the effectiveness of the pilot test section. CPT tip resistances were converted to equivalent SPT values. The average equivalent SPT blow counts measured before and after treatment are shown in Fig. 2.15. Average equivalent $\mathrm{N}$-values after treatment ranged from 21 to 33 . These results show that compaction grouting effectively compacted the hydraulic fill.

At the beginning of the production grouting program, grouting was performed from the top of the liquefiable layer downward, but without allowing the grout to harden between injection depths. Grout injection at each point continued until a drop in injection pressure or a constant injection pressure of $2.8 \mathrm{MPa}$ with less than $0.02 \mathrm{~m}^{3}$ per minute grout take or a surface heave of $3 \mathrm{~mm}$. However, sufficient compaction could not be achieved using this procedure.

After considering various alternatives, the grouting program was completed by grouting from the bottom up in two phases, from 4 to $2 \mathrm{~m}$ and from 11 to $2 \mathrm{~m}$. Injection depths were spaced $0.9 \mathrm{~m}$ apart. The final spacing between grout holes was $1.2 \mathrm{~m}$ on centers in a triangular grid pattern. The upper $2 \mathrm{~m}$ were excavated and recompacted after the grouting operation. Average equivalent SPT blow count after treatment ranged from 21 to 36 , as shown in Fig. 2.16. It was concluded that the hydraulic sand fill layer was sufficiently densified, with the minimum value of peak horizontal ground surface acceleration needed for liquefaction to occur equal to $0.35 \mathrm{~g}$.

During the 1989 Loma Prieta earthquake, the area experienced a peak horizontal ground surface acceleration of about $0.11 \mathrm{~g}$ (Mitchell and Wentz, 1991). No damage to the hospital addition was reported. Since the peak ground surface acceleration was rather low, the site has yet to be truly tested by large earthquake shaking. 
Table 2.1 - Case Studies of Liquefaction Remediation by Compaction Grouting.

\begin{tabular}{|c|c|c|c|c|}
\hline Site & $\begin{array}{c}\text { Site } \\
\text { Characteristics }\end{array}$ & $\begin{array}{l}\text { Reasons for } \\
\text { Method } \\
\text { Selection }\end{array}$ & $\begin{array}{c}\text { Construction } \\
\text { Program }\end{array}$ & Performance \\
\hline $\begin{array}{l}\text { Pinopolis West } \\
\text { Dam, Moncks } \\
\text { Corner, SC } \\
\text { (Salley et al., } \\
\text { 1987; Baez and } \\
\text { Henry, 1993). }\end{array}$ & $\begin{array}{l}\text { Loose sand to silty } \\
\text { sand } 1.2 \text { to } 2.4 \mathrm{~m} \\
\text { thick. Corrected } \\
\mathrm{N} \text {-values ranged } \\
\text { from } 0 \text { to } 7 \text { before } \\
\text { treatment. }\end{array}$ & $\begin{array}{l}\text { Critical layer } \\
\text { beneath existing } \\
\text { dam. }\end{array}$ & $\begin{array}{l}\text { Treatment to downstream toe. } \\
\text { Built berm to increase } \\
\text { confinement of critical layer. } \\
\text { Sand-cement grout with } \\
\text { slump less than } 76 \mathrm{~mm} \text {. } \\
\text { Stage up grouting in } 0.3 \mathrm{~m} \\
\text { increments. Final grid } \\
\text { spacing after three phases was } \\
1.8 \mathrm{~m} \text {. The average ratio of } \\
\text { injected grout volume to } \\
\text { treated volume was } 18 \% \text {. }\end{array}$ & $\begin{array}{l}\text { Corrected N-values } \\
\text { ranged from } 11 \text { to } 38 \\
\text { after treatment. }\end{array}$ \\
\hline $\begin{array}{l}\text { Kings Bay } \\
\text { Naval } \\
\text { Submarine } \\
\text { Base, GA } \\
\text { (Hussin and } \\
\text { Ali, 1987). }\end{array}$ & $\begin{array}{l}\text { Silty sand to sand } \\
\text { down to } 15 \mathrm{~m} \text {. } \\
\text { Before treatment } \\
\mathrm{N} \text {-values ranged } \\
\text { from } 1 \text { to } 40 ; \mathrm{CPT} \\
\text { tip resistances } \\
\text { varied between } 0.5 \\
\text { and } 24 \mathrm{MPa} \text {; } \mathrm{DMT} \\
\text { modulus ranged } \\
\text { from } 2 \text { to } 96 \mathrm{MPa} \text {. }\end{array}$ & $\begin{array}{l}\text { Bypass zone not } \\
\text { requiring } \\
\text { improvement, and } \\
\text { treat deep critical } \\
\text { layer. }\end{array}$ & $\begin{array}{l}\text { Sand-cement grout with } 51 \\
\text { mm-slump. Stage up } \\
\text { grouting. Final grid spacing } \\
2.7 \mathrm{~m} \text { on centers. }\end{array}$ & $\begin{array}{l}\text { CPT tip resistances } \\
\text { increased by as much } \\
\text { as } 100 \% \text {. }\end{array}$ \\
\hline $\begin{array}{l}\text { Test program at } \\
\text { Steel Creek } \\
\text { Dam, Savannah } \\
\text { River Plant, SC } \\
\text { (Keller et al., } \\
\text { 1987). }\end{array}$ & $\begin{array}{l}\text { Loose clayey sand. } \\
\text { Before treatment } \\
\mathrm{N} \text {-values less than } \\
10 ; \text { CPT tip } \\
\text { resistances less } \\
\text { than } 8 \mathrm{MPa} \text {; shear } \\
\text { wave velocities of } \\
120 \text { to } 140 \mathrm{~m} / \mathrm{s} \text {. }\end{array}$ & $\begin{array}{l}\text { Compaction } \\
\text { grouting was } \\
\text { generally } \\
\text { ineffective in the } \\
\text { clayey sand. }\end{array}$ & ---- & No data given. \\
\hline $\begin{array}{l}\text { New buildings, } \\
\text { Monaco } \\
\text { (Gambin, } \\
\text { 1991). }\end{array}$ & $\begin{array}{l}\text { Loose sand fill } \\
\text { with cobbles, } \\
\text { gravel and silt } \\
\text { between depths of } \\
7 \text { and } 18 \mathrm{~m} \text {. } \\
\text { Average Ménard } \\
\text { E-modulus of } 4 \text { to } \\
5 \mathrm{MPa} \text { before } \\
\text { treatment. }\end{array}$ & $\begin{array}{l}\text { Overlying strong } \\
\text { thick layer. Piling } \\
\text { too expensive. }\end{array}$ & $\begin{array}{l}\text { Stage up grouting. Primary } \\
\text { and secondary holes in square } \\
\text { pattern. Non critical areas-- } \\
\text { final spacing of } 3.6 \mathrm{~m} \text { and } \\
\text { grout volume of } 3.8 \% \text { of } \\
\text { treated soil volume. Critical } \\
\text { areas--final spacing of } 2.5 \mathrm{~m} \\
\text { and grout volume of } 4.8 \% \text {. }\end{array}$ & $\begin{array}{l}\text { Average Ménard E- } \\
\text { modulus of } 8 \text { to } 10 \\
\text { MPa after treatment. }\end{array}$ \\
\hline $\begin{array}{l}\text { Kaiser Hospital } \\
\text { addition, South } \\
\text { San Francisco, } \\
\text { CA (Mitchell } \\
\text { and Wentz, } \\
\text { 1991; Graf, } \\
\text { 1992a). }\end{array}$ & $\begin{array}{l}\text { Loose to medium } \\
\text { dense sand } 2.4 \text { to } \\
10.7 \mathrm{~m} \text { below } \\
\text { ground surface. } \\
\text { Average corrected } \\
\mathrm{N} \text {-values of } 15 \text { to } \\
26 \text { before grouting. }\end{array}$ & $\begin{array}{l}\text { Noise from pile } \\
\text { driving would have } \\
\text { been too disruptive } \\
\text { to hospital } \\
\text { operations. }\end{array}$ & $\begin{array}{l}\text { Sand-cement grout with } 25- \\
\text { mm slump. Stage up grouting } \\
\text { in } 0.9 \mathrm{~m} \text { increments. Final } \\
\text { grid spacing after two phases } \\
\text { was } 1.2 \mathrm{~m} \text { on centers. }\end{array}$ & $\begin{array}{l}\text { Average } N \text {-values } \\
\text { ranged from } 21 \text { and } \\
36 \text { after treatment. } \\
\text { No reported damage } \\
\text { after } 1989 \text { Loma } \\
\text { Prieta earthquake; } \\
\mathrm{a}_{\max }=0.11 \mathrm{~g} .\end{array}$ \\
\hline
\end{tabular}


Table 2.1 - Case Studies of Liquefaction Remediation by Compaction Grouting (cont.).

\begin{tabular}{|c|c|c|c|c|}
\hline Site & $\begin{array}{c}\text { Site } \\
\text { Characteristics }\end{array}$ & $\begin{array}{c}\text { Reasons for } \\
\text { Method } \\
\text { Selection }\end{array}$ & $\begin{array}{l}\text { Construction } \\
\text { Program }\end{array}$ & Performance \\
\hline $\begin{array}{l}\text { Bridge } \\
\text { abutments, } \\
\text { Imperial } \\
\text { County, CA } \\
\text { (Hayden and } \\
\text { Baez, 1994). }\end{array}$ & Sands to $9 \mathrm{~m}$. & $\begin{array}{l}\text { Prevent lateral } \\
\text { spreading and } \\
\text { damage to new } \\
\text { bridge. }\end{array}$ & No data given. & No data given. \\
\hline $\begin{array}{l}\text { Pier, San } \\
\text { Francisco, CA } \\
\text { (Hayden and } \\
\text { Baez, 1994). }\end{array}$ & $\begin{array}{l}\text { Liquefiable sands } \\
\text { and silty sands. }\end{array}$ & $\begin{array}{l}\text { Treatment beneath } \\
\text { existing pier } \\
\text { following } 1989 \\
\text { Loma Prieta } \\
\text { earthquake. }\end{array}$ & No data given. & No data given. \\
\hline $\begin{array}{l}\text { Detention } \\
\text { Center, San } \\
\text { Fernando, CA } \\
\text { (Hayden and } \\
\text { Baez, 1994). }\end{array}$ & $\begin{array}{l}\text { Liquefiable soil at } \\
6 \text { to } 9 \mathrm{~m} \text { depths. }\end{array}$ & Existing building. & No data given. & No data given. \\
\hline $\begin{array}{l}\text { Three houses, } \\
\text { Los Altos, CA } \\
\text { (Hayden and } \\
\text { Baez, 1994). }\end{array}$ & $\begin{array}{l}\text { Silt and sands to } \\
4.6 \mathrm{~m} \text {. }\end{array}$ & No reason given. & No data given. & No data given. \\
\hline $\begin{array}{l}\text { Warehouse, } \\
\text { Burlingame, } \\
\text { CA (Hayden } \\
\text { and Baez, } \\
\text { 1994). }\end{array}$ & $\begin{array}{l}\text { Silts and sands to } 6 \\
\mathrm{~m} \text {. }\end{array}$ & No reason given. & No data given. & No data given. \\
\hline $\begin{array}{l}\text { Tower, Port } \\
\text { Mellon, BC, } \\
\text { Canada } \\
\text { (Hayden and } \\
\text { Baez, 1994). }\end{array}$ & $\begin{array}{l}\text { Liquefiable soils } \\
\text { beneath mat } \\
\text { foundation to a } \\
\text { depth of } 18 \mathrm{~m} \text {. }\end{array}$ & $\begin{array}{l}\text { Existing } 61 \mathrm{~m} \text { high } \\
\text { tower. }\end{array}$ & No data given. & No data given. \\
\hline
\end{tabular}




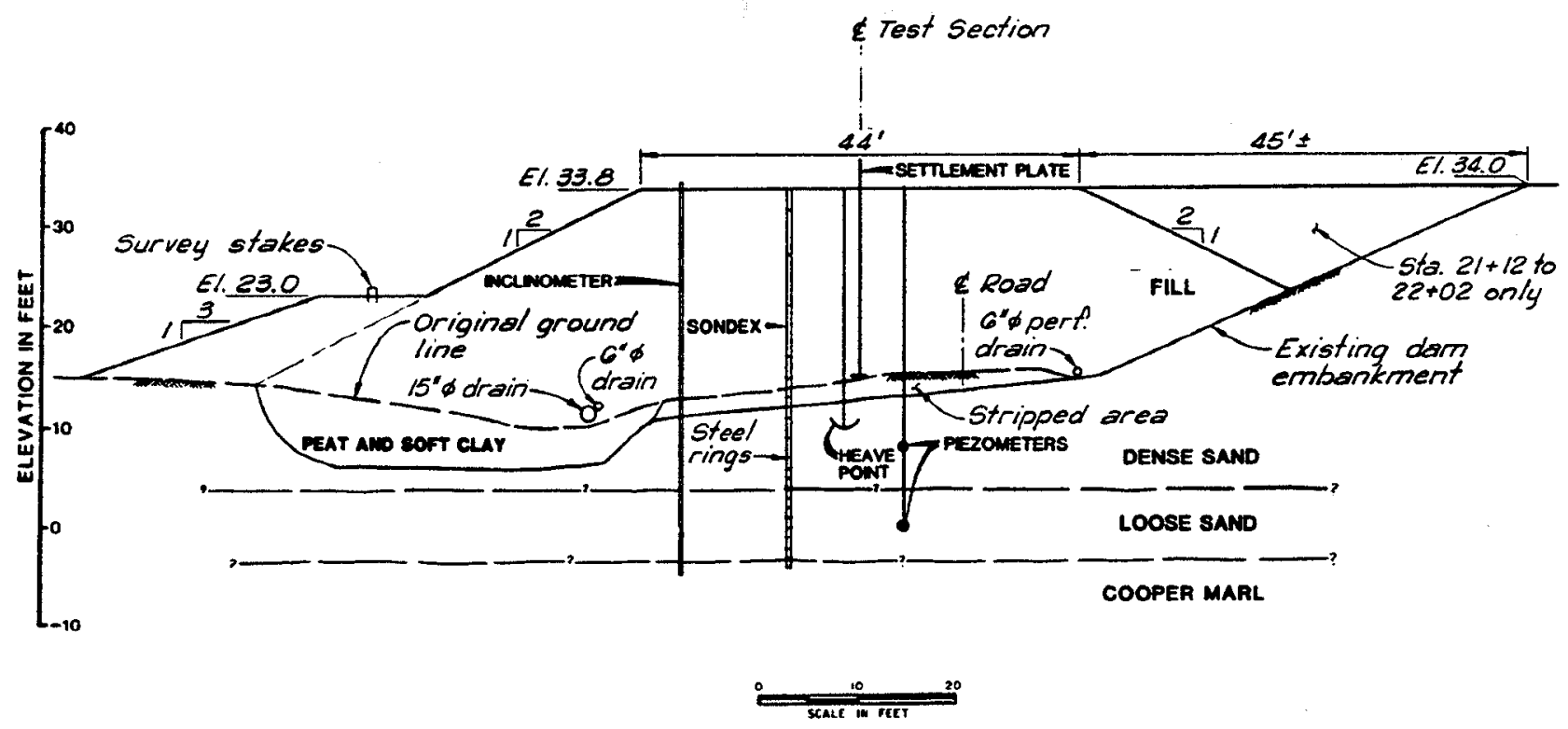

Fig. 2.2 - Typical Cross Section of Pilot Study Area at the Downstream Toe of the Pinopolis West Dam (Salley et al., 1987). (1 ft =0.3 m.)

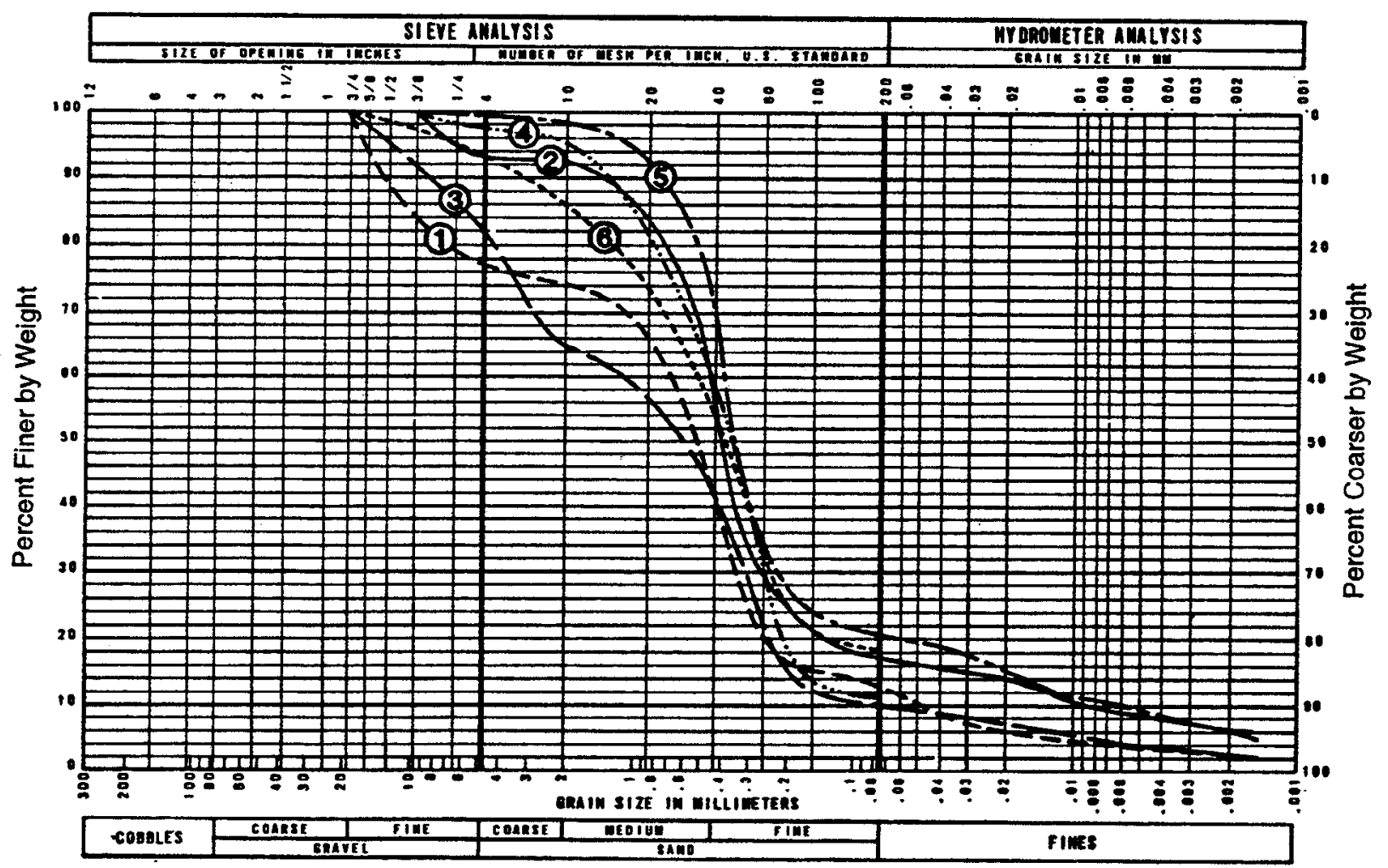

Fig. 2.3 - Grain-size Distribution Curves of Split-Barrel Samples Taken from the Loose Sand at the Pinopolis West Dam (Salley et al., 1987). 


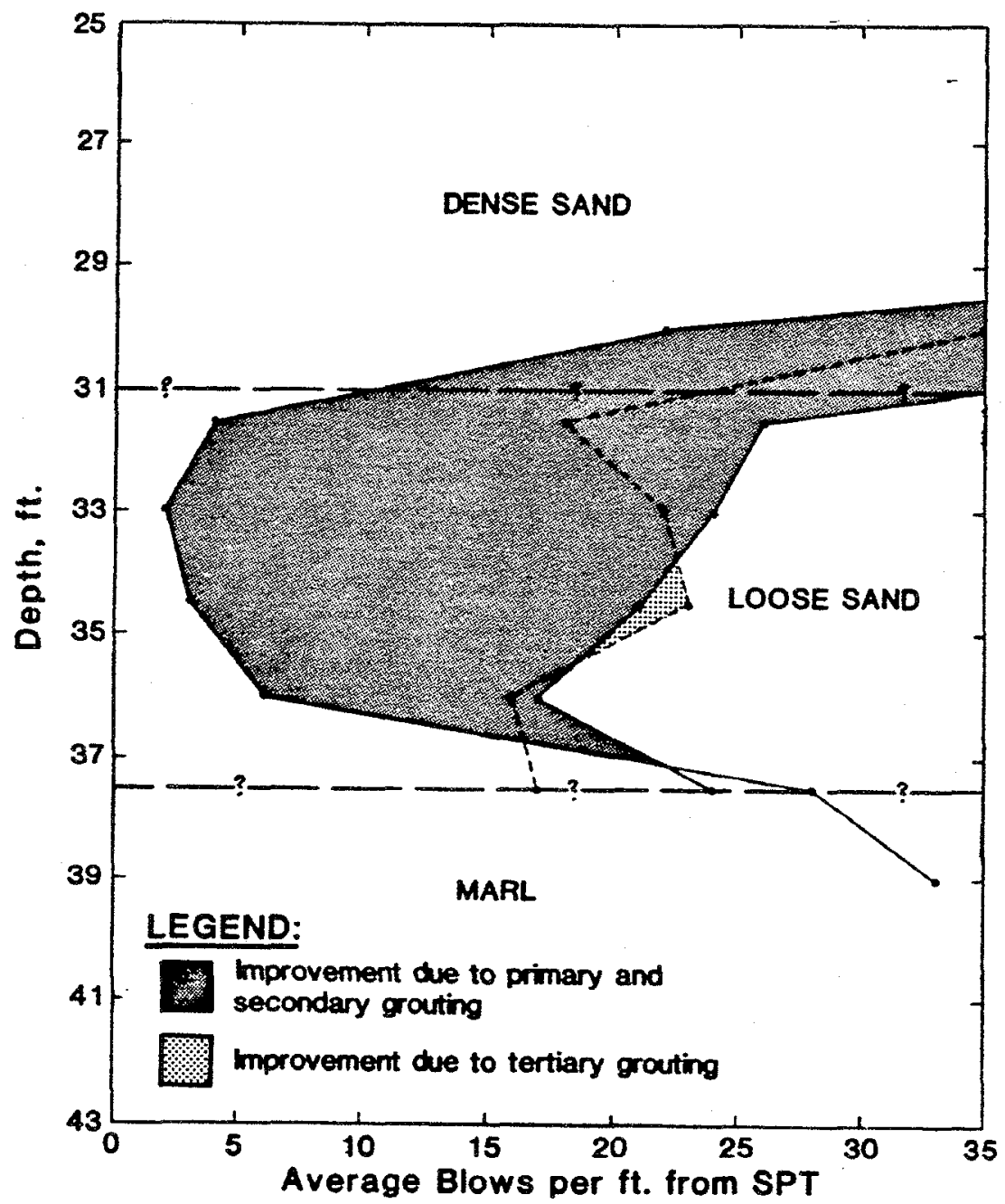

Fig. 2.4 - Average Corrected SPT Blow Count from Pilot Study Site Treated by Compaction Grouting at the Pinopolis West Dam (Salley et al., 1987). Before and After SPT Profiles are Plotted with the Improvement Shaded. $(1 \mathrm{ft}=0.3 \mathrm{~m}$.) 


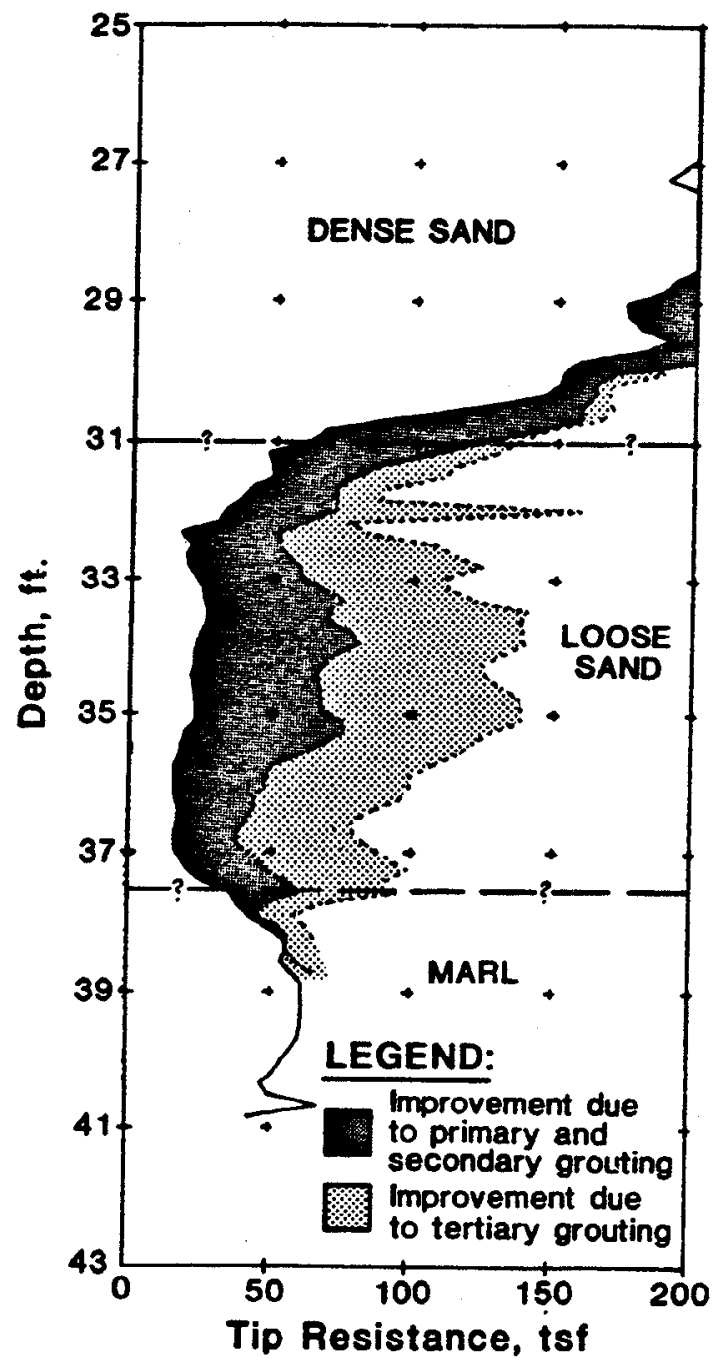

Fig. 2.5 - Average Cone Penetration Profiles from Pilot Study Site Treated by Compaction Grouting at the Pinopolis West Dam (Salley et al., 1987). Before and After Cone Tip Resistance Profiles are Plotted with the Improvement Shaded. ( $1 \mathrm{ft}=0.3 \mathrm{~m} ; 1$ ton $/ \mathrm{ft}^{2}$ $=96 \mathrm{kPa}$.) 


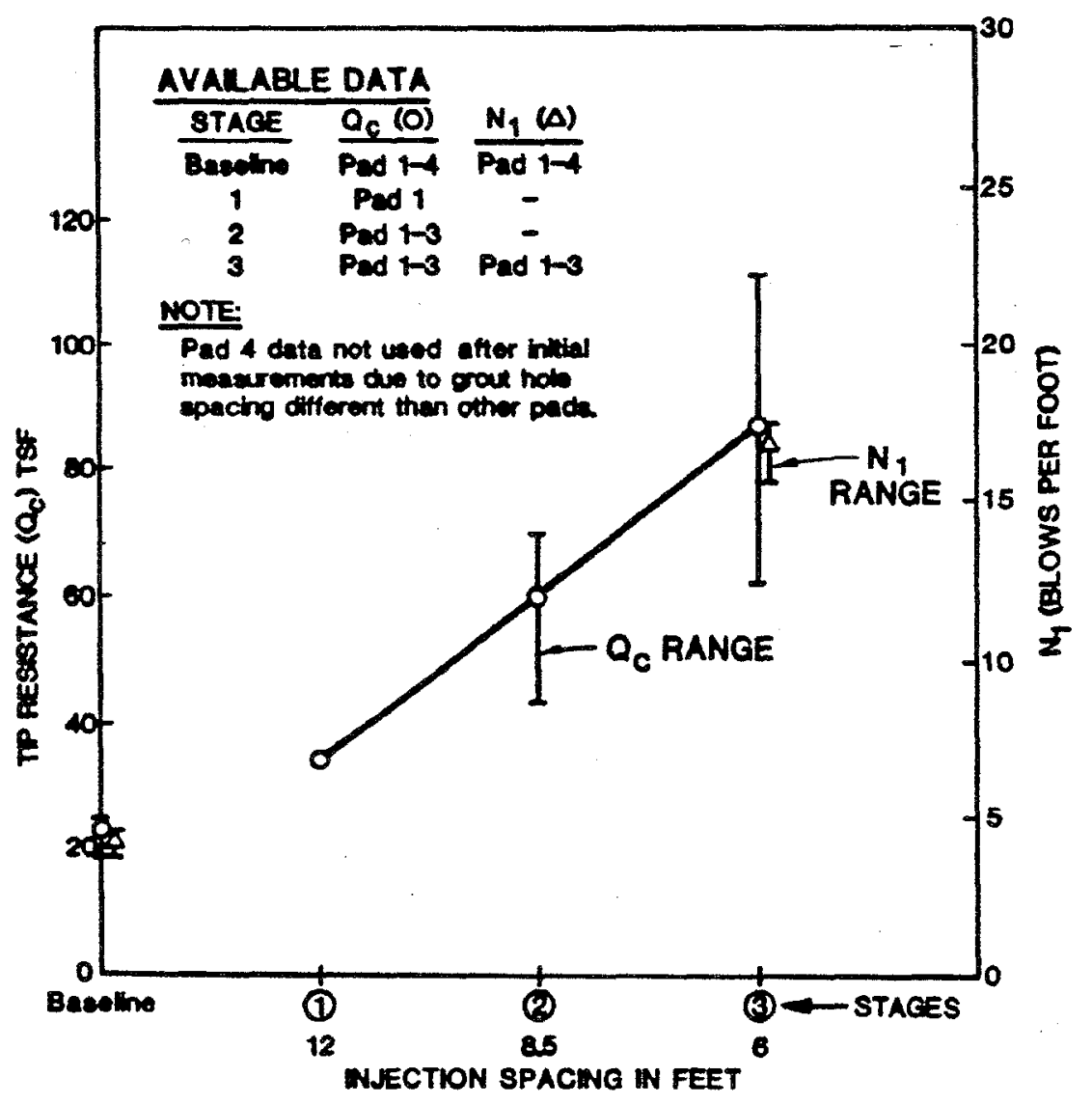

Fig. 2.6 - Improvement in Penetration Resistance Relative to Grout Injection Spacing from Pilot Study Site Treated by Compaction Grouting at the Pinopolis West Dam (Salley et al., 1987). The Relative Position of Scales for Cone Tip Resistance and SPT Blow Count is Based on a Ratio of Tip Resistance to $\mathrm{N}_{1}$ Equal to 5 . ( $1 \mathrm{ft}=0.3 \mathrm{~m} ; 1$ ton/ $/ \mathrm{ft}^{2}$ $=96 \mathrm{kPa}$.) 


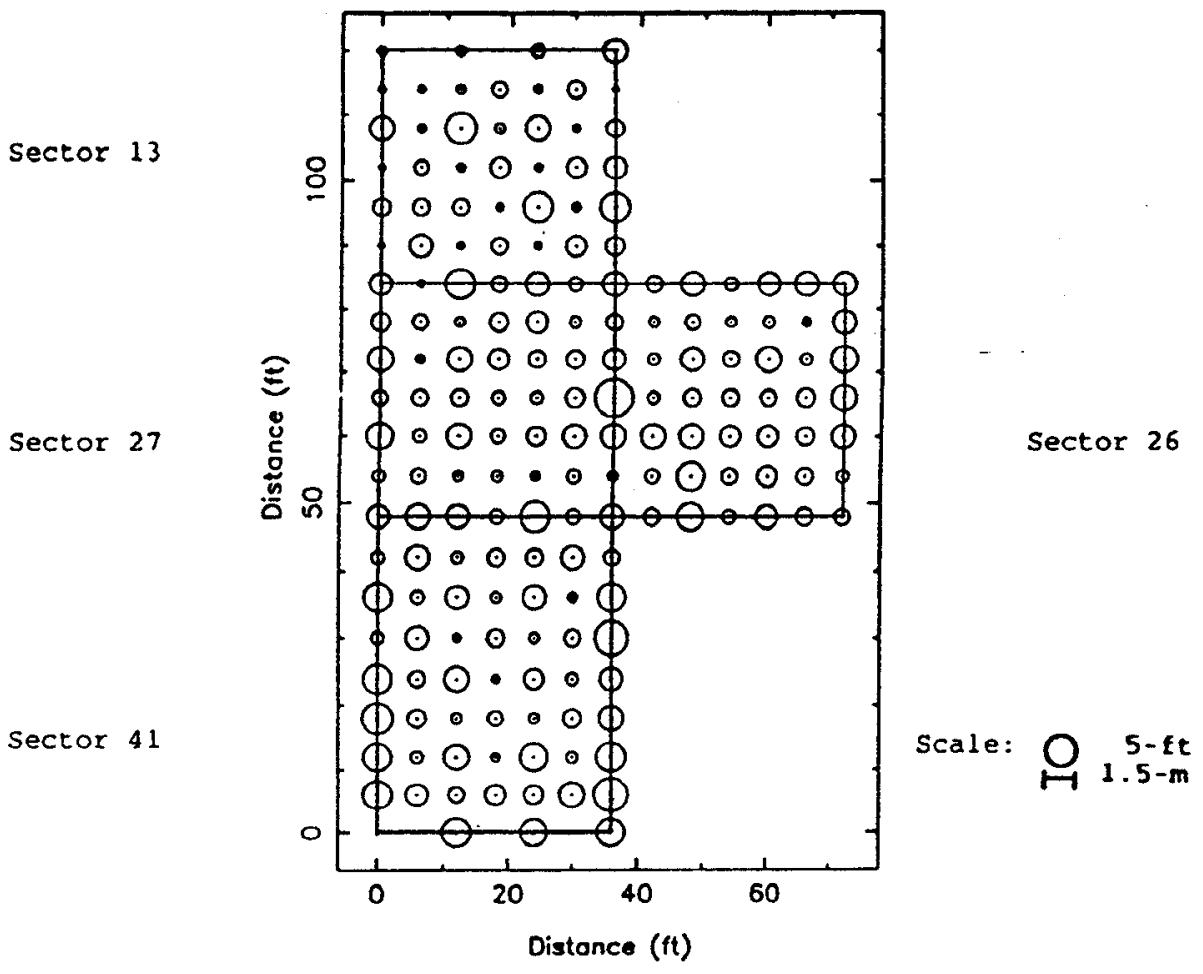

Fig. 2.7 - Equivalent Scaled Compaction Grout Column Diameter For Several Injection Location at Pinopolis West Dam (Baez and Henry, 1993). ( $(\mathrm{ft}=0.3 \mathrm{~m}$.)

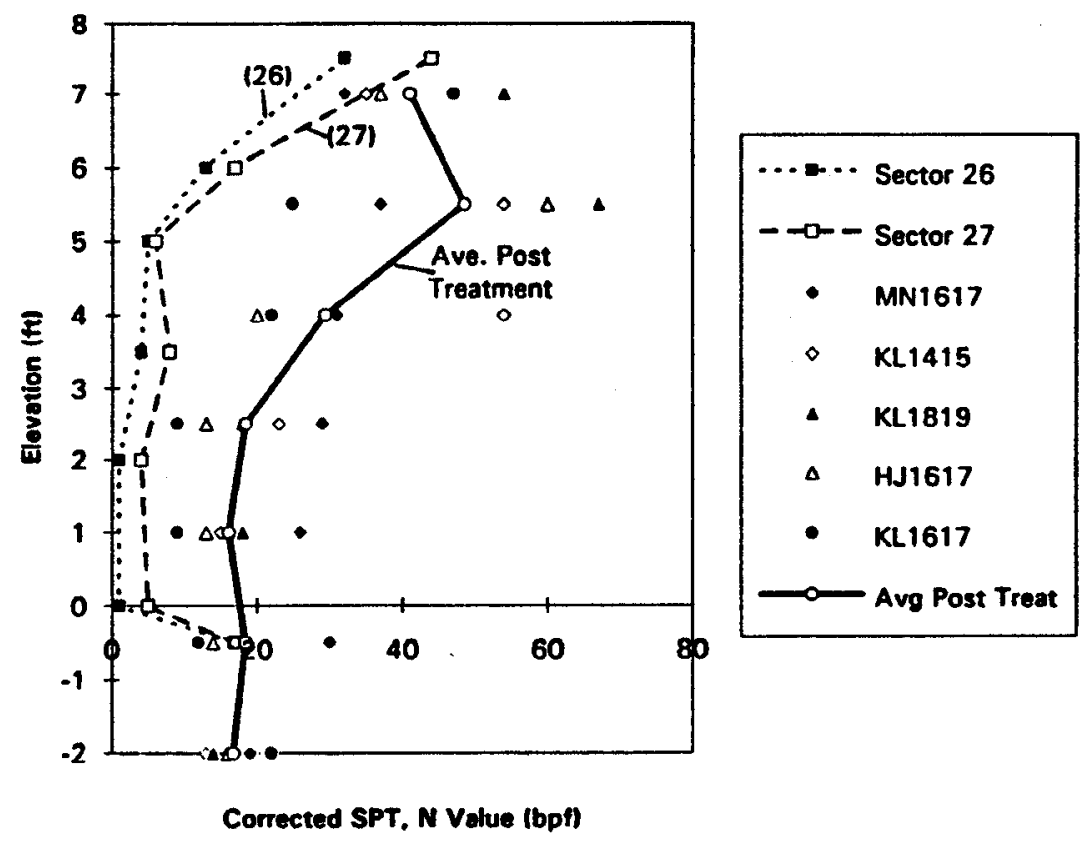

Fig. 2.8 - Profiles of Average Corrected SPT Blow Count from Site Treated by Compaction Grouting at the Pinopolis West Dam (Baez and Henry, 1993). Before Treatment Profiles are Dashed. ( $1 \mathrm{ft}=0.3 \mathrm{~m}$.) 


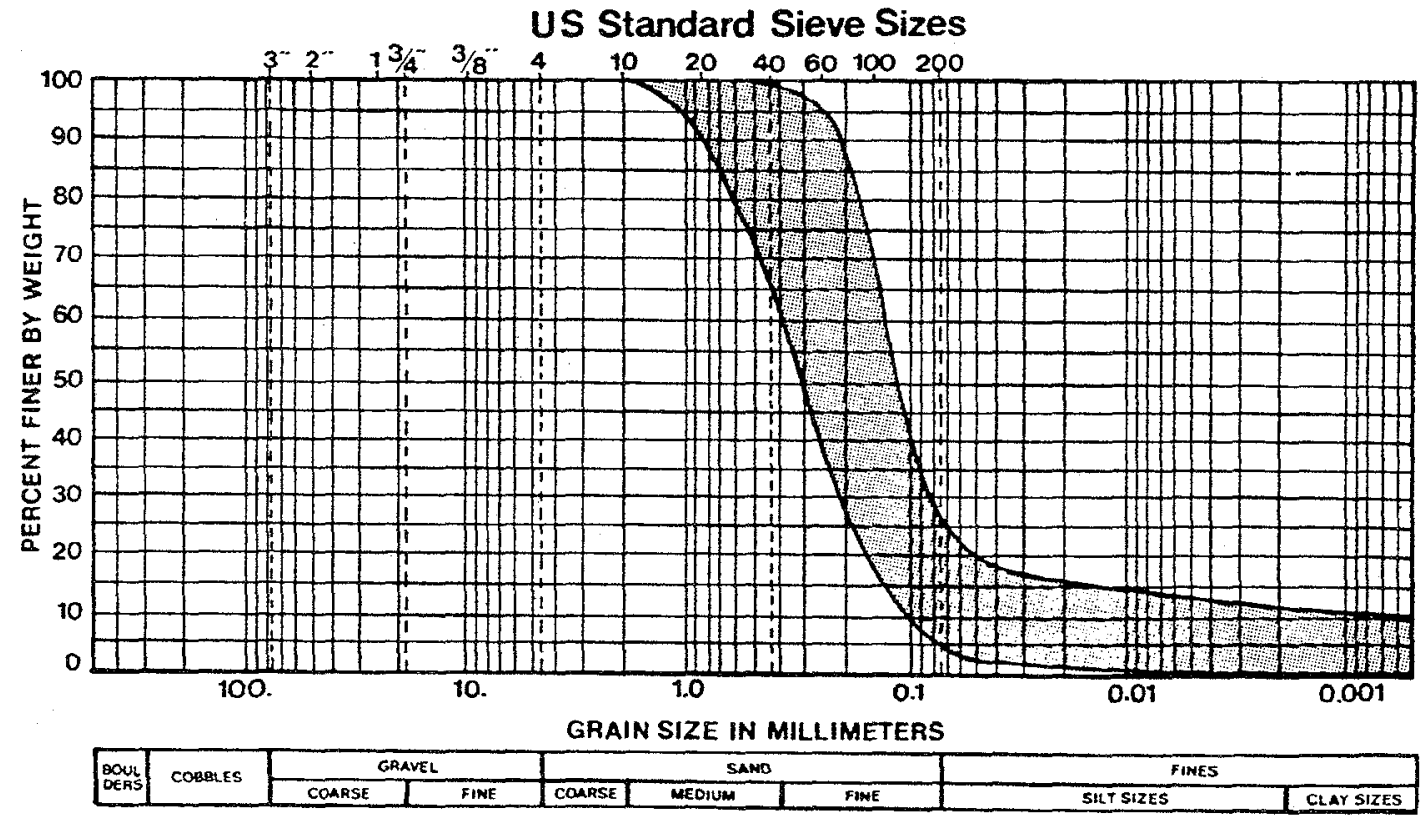

Fig. 2.9 - Grain-Size Distribution Curves for Foundation Sands at Kings Bay Naval Base (Hussin and $\mathrm{Ali}, 1987$ ). 


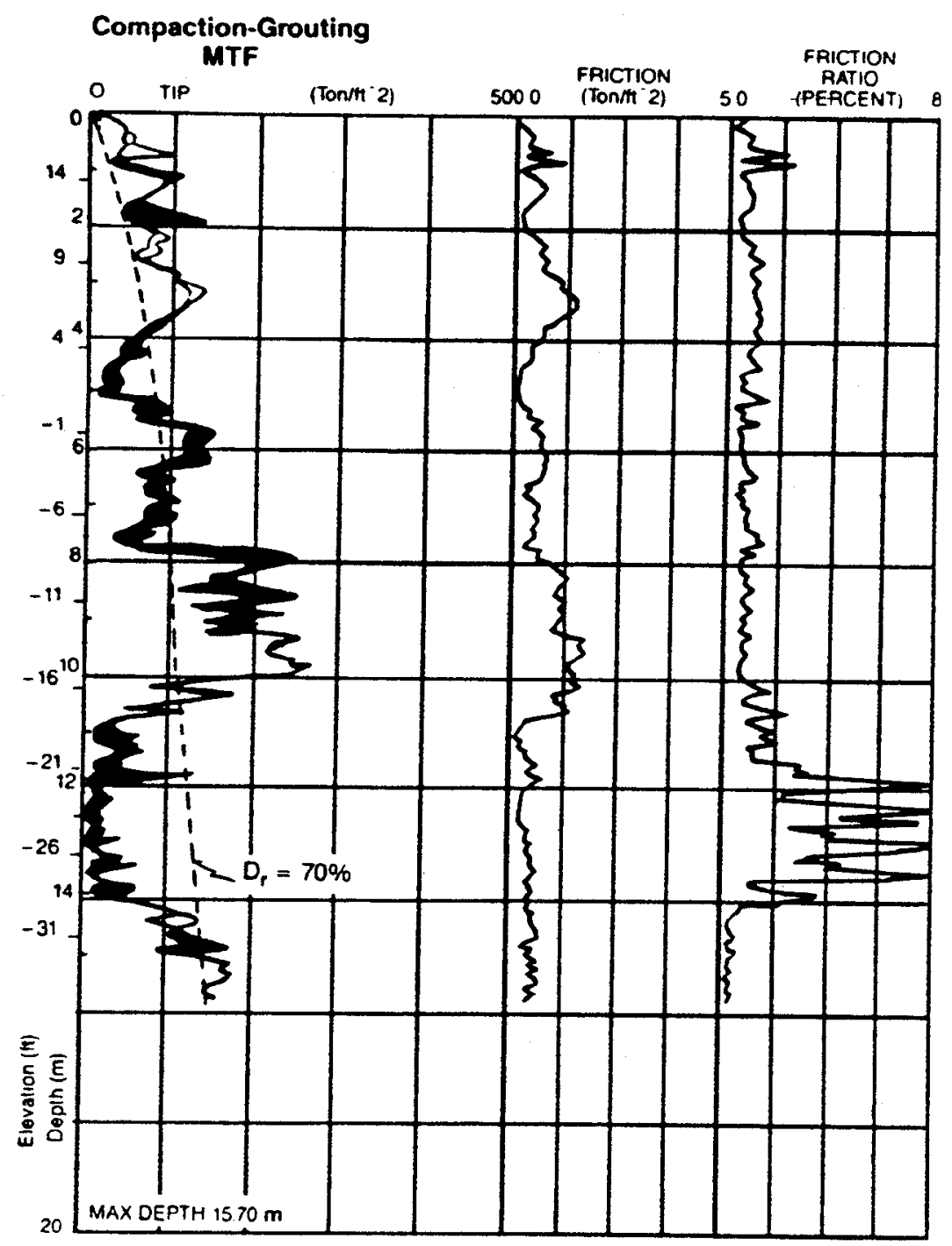

Fig. 2.10 - Cone Penetration Profiles from Site Treated by Compaction Grouting at the Kings Bay Naval Submarine Base (Hussin and Ali, 1987). Before and After Cone Tip Resistance Profiles are Plotted on the Left with the Improvement Shaded. $(1 \mathrm{ft}=$ $0.3 \mathrm{~m}$.) 


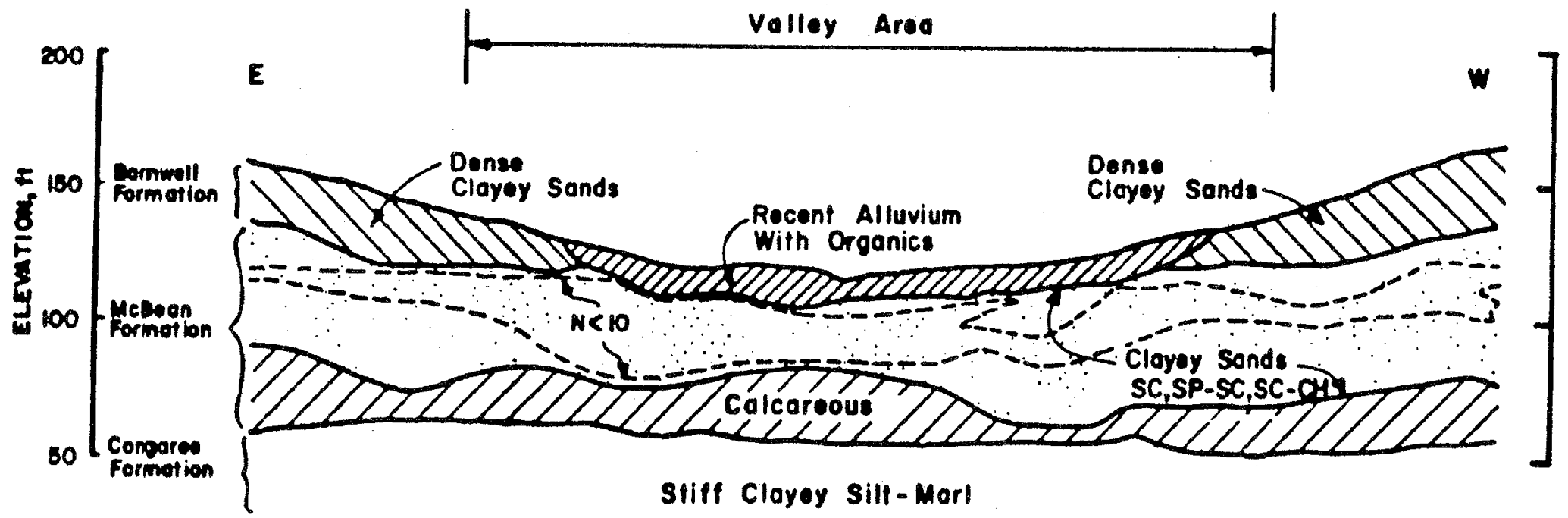

Dosed On Mueser Rupledoe

Consulting Engineare' Soil Profile

Fig. 2.11 - Simplified Soil Profile of Foundation Soils at the Steel Creek Dam, South Carolina (Keller et al., 1987).
$(1 \mathrm{ft}=0.3 \mathrm{~m}$.) 


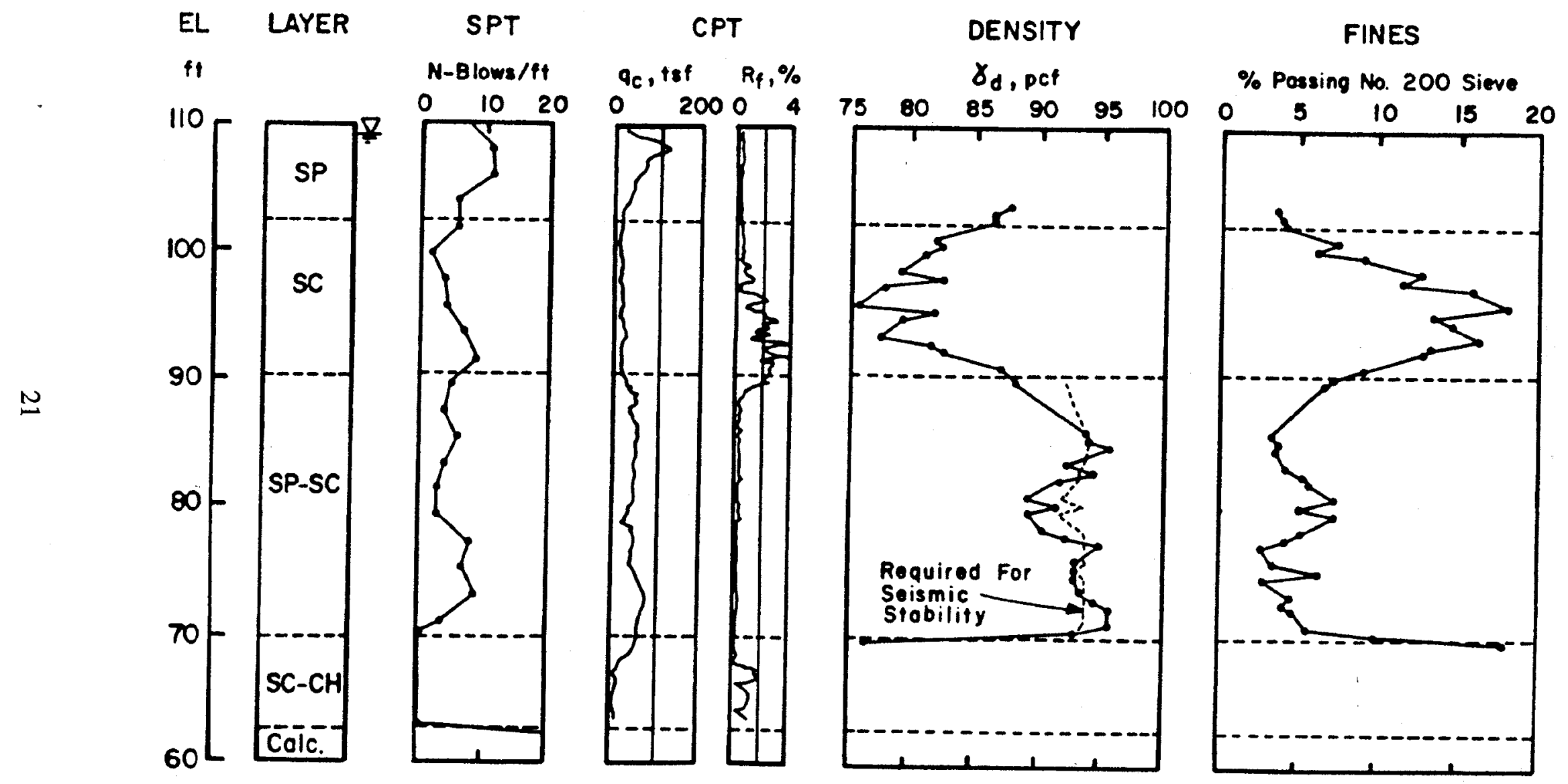

Fig. 2.12 - Typical Soil, Penetration and Density Profiles of Foundation Soils at the Steel Creek Dam, South Carolina (Keller et al., 1987). $\left(1 \mathrm{ft}=0.3 \mathrm{~m} ; 1\right.$ ton/f $\mathrm{f}^{2}=96 \mathrm{kPa} ; 1 \mathrm{pcf}=0.157 \mathrm{kN} / \mathrm{m}^{3}$.) 

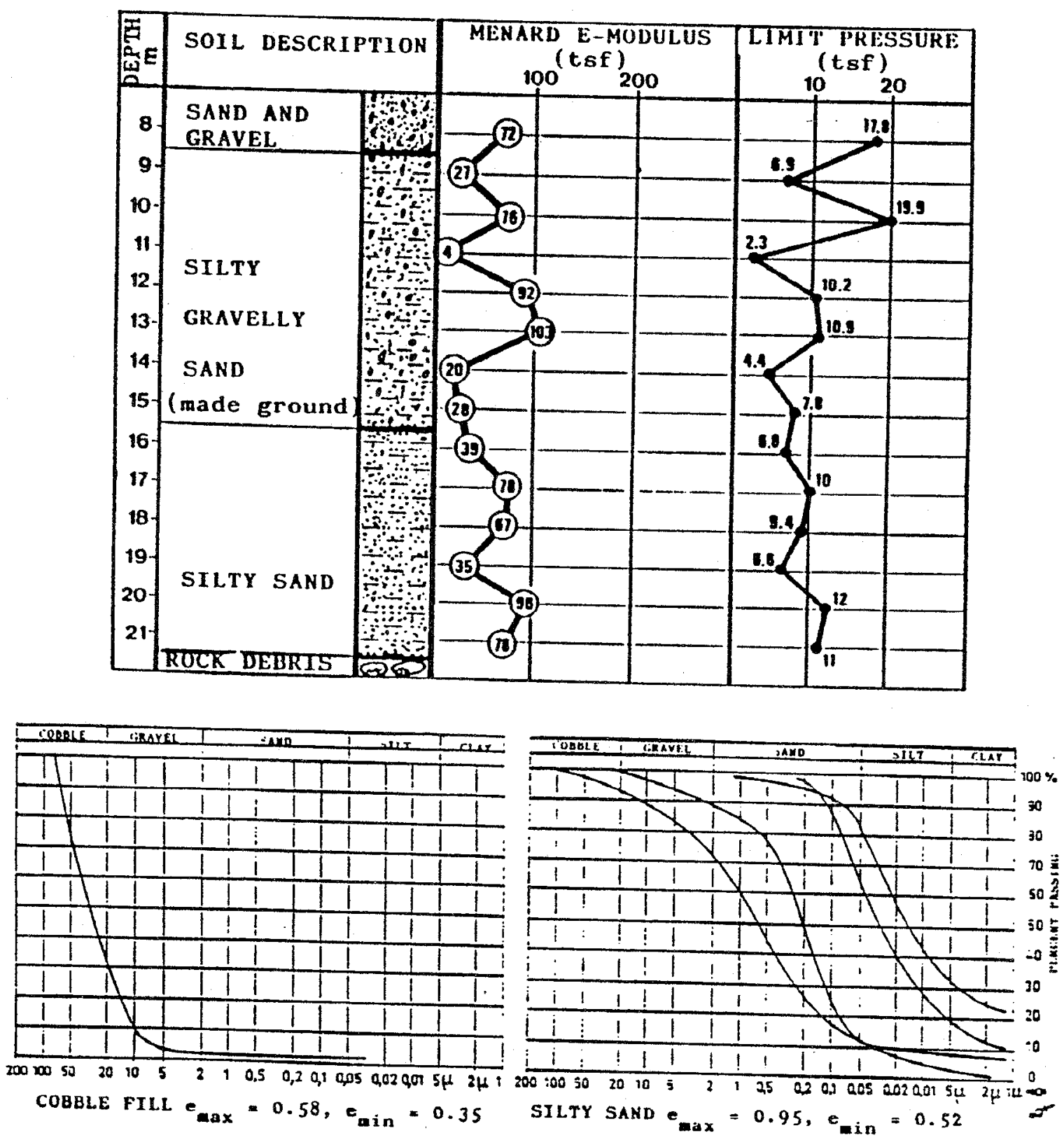

Fig. 2.13 - Typical Soil and Pressuremeter Profiles, and Grain-Size Distribution Curves at Fontvieille Zone D, Monaco (Gambin, 1991). (1 tsf = $96 \mathrm{kPa}$.) 
Profile A

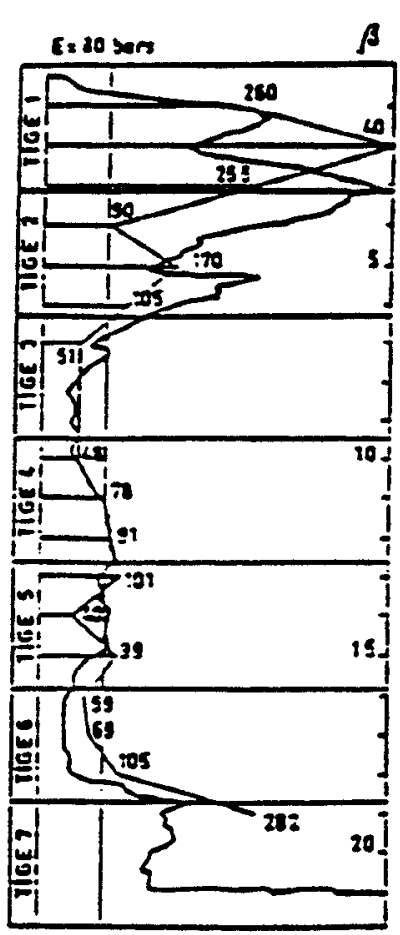

Profile B

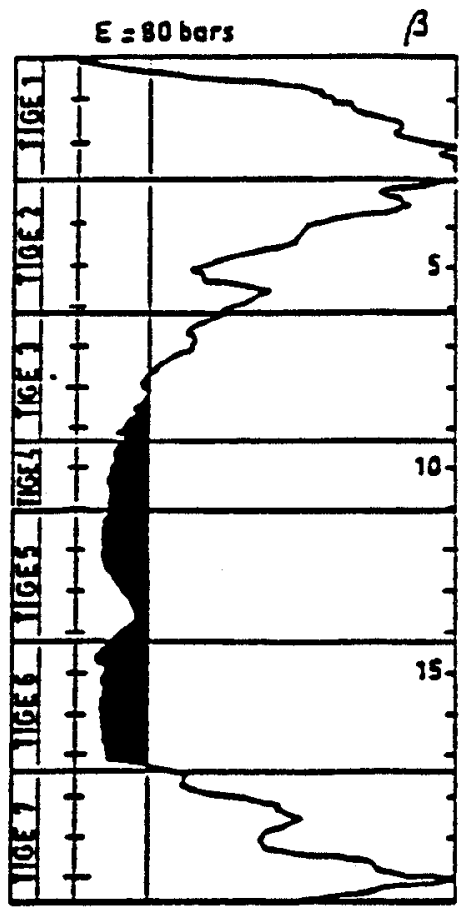

Profile C

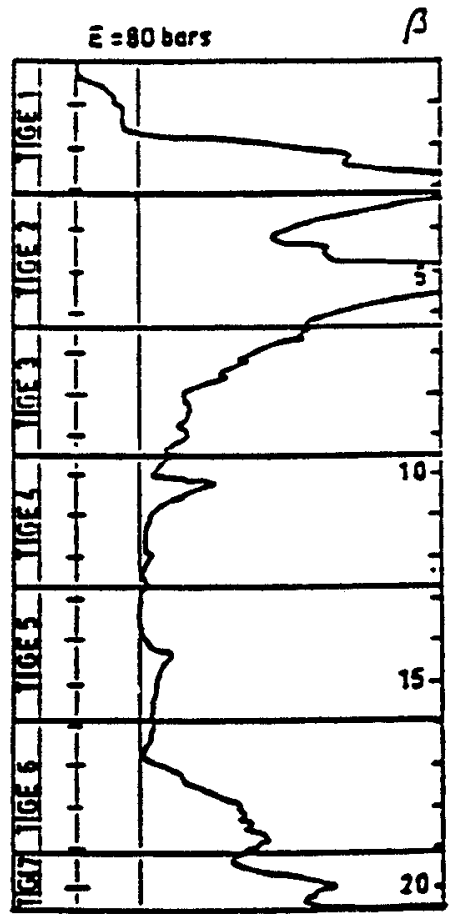

Fig. 2.14 - Profile A Shows Proportional Relationship between Ménard E-modulus and a Combined Drilling Parameter, called $\beta$. Before and After Values of $\beta$ are Plotted as Profiles B and C. The Shaded Zone in Profile B Expresses the Critical Zone. (1 bar $=0.1 \mathrm{MPa}$ ) 


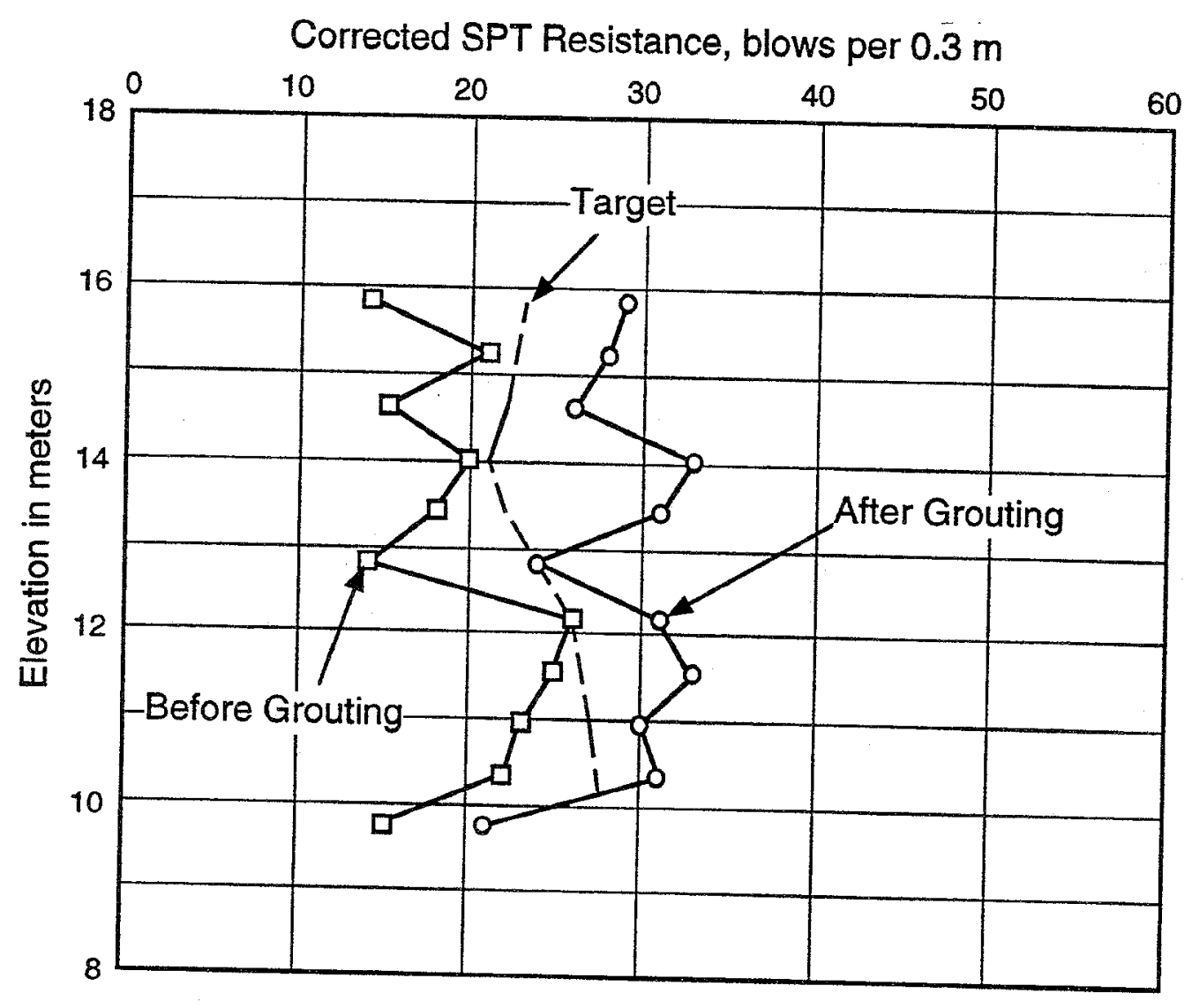

Fig. 2.15 - Profiles of Average Equivalent SPT Blow Count from Pilot Study Site Treated by Compaction Grouting at the Kaiser Hospital Addition, South San Francisco (after Mitchell and Wentz, 1991). 


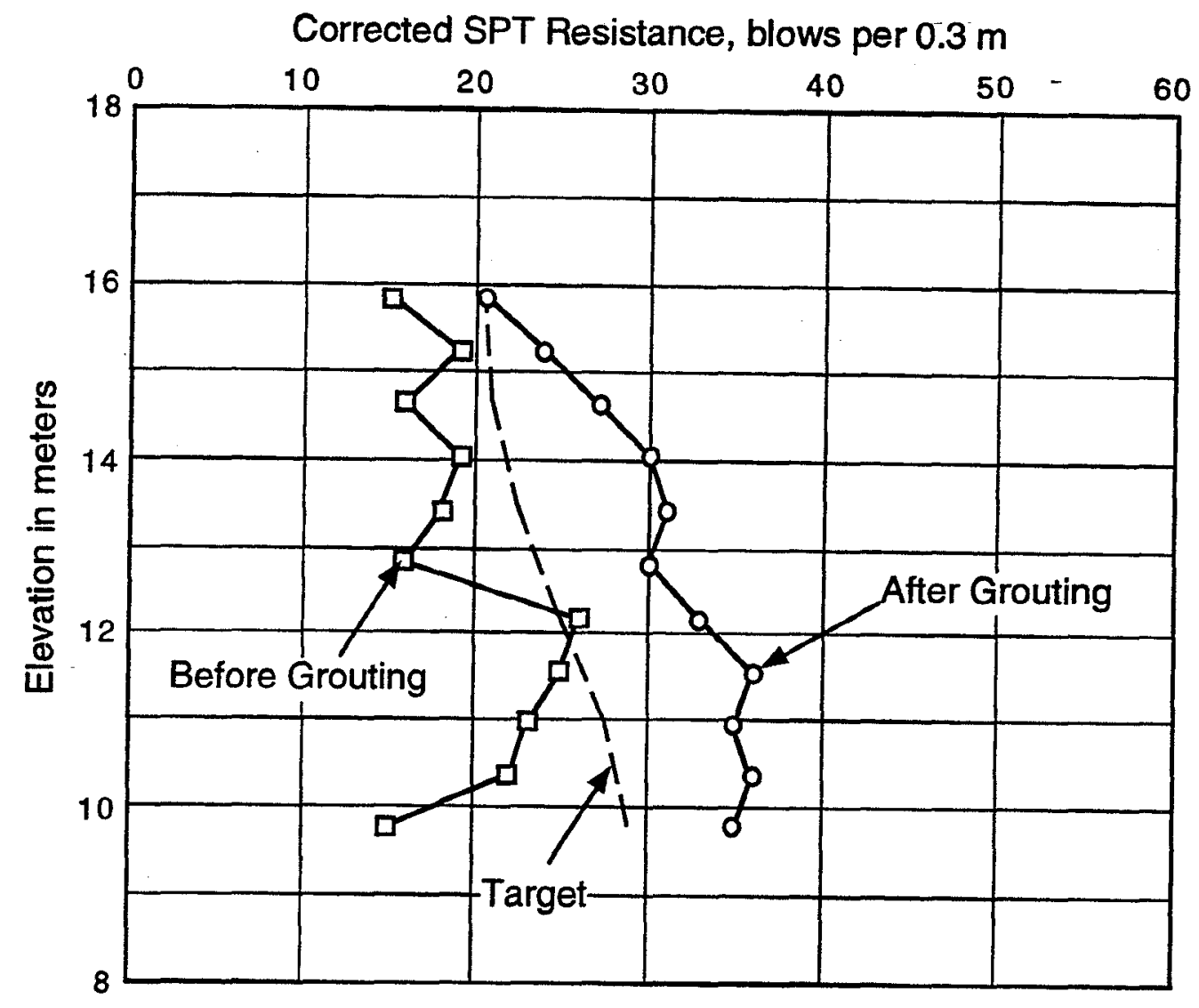

Fig. 2.16 - Profiles of Average SPT Blow Count from Site Treated by Compaction Grouting at the Kaiser Hospital Addition, South San Francisco (after Mitchell and Wentz, 1991). 


\subsection{PERMEATION GROUTING}

\subsubsection{General}

Permeation grouting is the injection of low viscosity particulate or chemical fluids into soil pore space with little change to the physical structure of the soil. The major objective of permeation grouting is either to strengthen ground by cementing soil particles together or to reduce water flow by plugging soil pores. A conceptual diagram of permeation grouting is shown in Fig. 2.17. The history of permeation grouting can be traced to the late $1800 \mathrm{~s}$ (Glossop, 1961). The permeation grouting technique has been successfully used to control ground water flow, stabilize excavations in soft ground, underpin existing foundations, and prevent seismically induced settlement and liquefaction.

There are a number of factors which influence the effectiveness of permeation grouting (Baker, 1982; Perez et al., 1982; Littlejohn, 1993; Greenwood, 1994) including:

1. Soil Being Permeated. Clean granular soils are easier to permeate than fine-grained soils. Soil permeability is the single most useful index. Porosity dictates the amount of grout consumed. Other important parameters include grain size, soil fabric and stratigraphy.

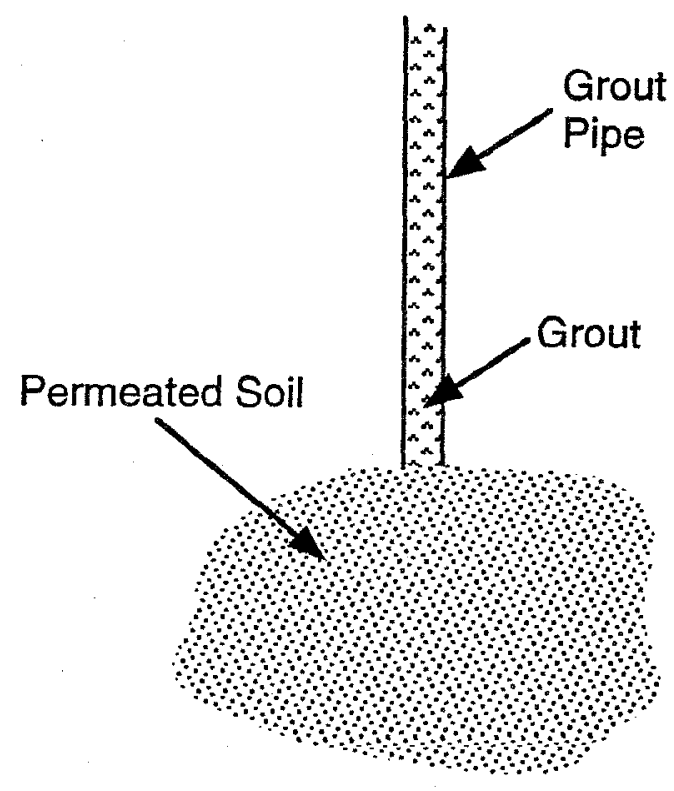

Fig. 2.17 - Conceptual Diagram of Soil Solidification by Permeation Grouting. 
2. Earth Pressures. Ground fracture and heave occur when overburden pressure is low, and injection pressure and rate are high. Fractures can extend for great lengths since the grout is water-like, and there is little loss of pressure along them. Fractures develop before heave is observed at the ground surface.

3. Ground Water Conditions. Grout could be leached out of soil by seepage, or attacked chemically or biologically. Some chemical grouts crack where water level fluctuates.

4. Grout Mix. Particulate grouts, or suspensions, may consist of Portland cement, microfine cement, fly ash, clay, and water. Chemical grout types, or solutions, include sodium silicates, acrylamides, lignosulfonates, and resins (Karol, 1982). Sodium silicate grouts are the most widely used chemical grout for soil strengthening. The acrylamides in solution or powder form, and the catalyst used in lignosulfonates are highly toxic. Special handling and mixing procedures may be required to insure the health and safety of workers, and to protect the environment. Grout particle size, viscosity, temperature, setting time, stability, strength, creep, and durability must be considered. In general, ordinary Portland cement grouts will not permeate most sands, micro-fine cement grouts will not permeate medium- to finegrained sand, and chemical grouts will not permeate sands containing more than about $25 \%$ silt and clay.

5. Grout Injection Pressure and Rate. Excessive injection pressures and rates will result in ground fracture and heave. It has been recommended that injection pressures be kept to about $25 \%$ of the fracture pressure determined by field trial.

6. Grout Injection Volume. Uneven distribution of grout will likely result in uneven improvement.

7. Grout Hole Spacing. Holes spaced too far apart will leave zones of untreated soil. Typical final hole spacings range from 0.5 to $2 \mathrm{~m}$.

8. Injection Sequence. Effective sequencing will utilize confinement created in previous work. Grout initially penetrates the more open soil leaving soils of lower permeability untreated. For a more uniform treatment, it has been recommended to inject predetermined grout quantities, and split spacings and depths of injection in successive phases.

According to Welsh $(1992 ; 1995)$, the cost to mobilize and demobilize permeation grouting equipment ranges from $\$ 15,000$ to $\$ 25,000$ per rig for projects using micro-fine cement grout, and over $\$ 25,000$ per rig for projects using sodium silicate grout. To install sleeve port grout pipes, the cost is over $\$ 50$ per meter of pipe. This cost would double for low headroom work. The cost of injection labor and grout materials start at about $\$ 130$ per cubic meter of improved soil for micro-fine cement grout, and about $\$ 200$ per cubic meter of improved soil for sodium silicate grout. The cost of labor and materials is based on a $20 \%$ grout take, and a total grout volume greater than about $200 \mathrm{~m}^{3}$. 


\subsubsection{Liquefaction Remediation}

Available case studies where permeation grouting was used to solidify loose soils for reducing seismic-induced settlement and liquefaction potential are summarized in Table 2.2. These case studies involved treatment beneath existing structures and around a tunnel under construction. Three of the cases are reviewed in more detail below.

\subsubsection{Riverside Avenue Bridge, Santa Cruz}

From the report by Mitchell and Wentz (1991), the Riverside Avenue Bridge over the San Lorenzo River in Santa Cruz, California, is supported by reinforced concrete nose piers. The river was eroding away the soil beneath the south nose pier. Some settlement had occurred, causing damage to the bridge decking above. The river channel beneath the bridge and nose piers is lined by a concrete slab-apron. The upper $5 \mathrm{~m}$ of soil beneath the slab-apron consisted of saturated, loose to dense sandy gravel with a maximum size of $25 \mathrm{~mm}$. The gravel was underlain by a 3.4-m thick layer of dense gravelly sand with less than 5\% fines (silt and clay). Sediments below the sand were composed of alternating layers of clay and silt. The water level of the river at high tide was $2.7 \mathrm{~m}$ above the bottom of the slab-apron.

Permeation grouting was considered the technique best suited for remedial work beneath the nose pier and slab-apron. As review by Mitchell and Wentz (1991), holes were drilled through the concrete nose pier and slab-apron for grout injection beneath and around the pier. Steel sleeve port grout pipes were passed through each drilled hole and vibrated or jetted into the granular soil. Grout consisting of sodium silicate N grade and MC 500 micro-fine cement was injected through the sleeve port pipes and into the surrounding granular soil. The set time was controlled by adding to the grout mix less than $0.1 \%$ by volume of phosphoric acid. (No mention was made in the review about the environmental impact of using phosphoric acid or special handling procedures.) A total of $160 \mathrm{~m}^{3}$ of grout was injected into 77 locations within the 15 day limit. In addition, a nearby area was injected to evaluate the effectiveness of the grouting program. Samples of grouted soil taken from taken from this area exhibited suitable strength.

During the 1989 Loma Prieta earthquake, the site experienced a maximum ground surface acceleration of about $0.45 \mathrm{~g}$ (Mitchell and Wentz, 1991). No settlement or detrimental ground movement was observed around the concrete slab-apron after the earthquake.

\subsubsection{Roosevelt Junior High School, San Francisco}

From the report by Graf and Zacher (1979), Roosevelt Junior High School in San Francisco, California, is a three-story structure supported by spread-column and perimeter-wall footings, founded on wind-blown sand containing less than $5 \%$ fines. The school was built around 1930. SPT blow counts measured in the upper $4.6 \mathrm{~m}$ of soil ranged from 3 to 15 . Below $4.6 \mathrm{~m}$, blow counts were more than 20 . The water table was well below the near-surface loose sand. It was determined that the loose (low blow count) sand could densify and settle during strong ground shaking. 
Permeation grouting was considered to be less expensive than underpinning existing footings and pouring larger footings. Contract drawings showing the injection patterns for existing spread footings and new wall footings are presented in Fig. 2.18. As described by Graf and Zacher (1979), a 13-mm grout pipe was first installed to the shallowest injection depth. A predetermined amount of grout was injected through the pipe at a rate of 20 to $30 \mathrm{l} / \mathrm{min}$. The pipe was then advanced $0.3 \mathrm{~m}$ to the next injection depth, and the process repeated. The grout was an organic resin (R.E.G.) with a viscosity of 3 to $4 \mathrm{mPa} \cdot \mathrm{sec}$. Grout holes were generally spaced 0.9 to $1.5 \mathrm{~m}$ apart. Some of the work was performed in the small crawl space (less than $1.1 \mathrm{~m}$ high) under the floor slab. The unconfined compressive strengths of six specimens collected in test pit excavations ranged from 267 to $879 \mathrm{kPa}$, with an average value of $618 \mathrm{kPa}$.

No foundation settlement was observed at the school following the 1989 Loma Prieta earthquake (Graf, 1992a). Based on reported ground surface accelerations (Darragh and Shakal, 1991), this area of San Francisco experienced a peak horizontal acceleration of about $0.15 \mathrm{~g}$. Since this was a relatively low acceleration, the site has yet to be truly tested by large earthquake shaking.

\subsubsection{Supermarket at 4041 Geary Street, San Francisco}

A concrete structure was to be remodeled into a supermarket. The structure, built around 1940, is located in San Francisco, California, near Roosevelt Junior High School. As reported by Graf (1992a), the foundation soils were composed of sand with little fines. The ground water table was well below the near-surface loose sand. It was determined that the loose sand could densify and settle during strong ground shaking.

Permeation grouting was used to enlarge the existing footings, and to extend them downward to a denser sand layer. Holes were drilled through the existing footings to allow injection directly below footings. Grout pipe was jetted with the chemical grout to the shallowest injection depth. A predetermined quantity of grout was injected through the 13-mm ( 0.5 in.) diameter pipe. The pipe was then advanced downward to the next injection depth, and the process repeated. In areas where strength was not critical, a sodium silicate based grout with an inorganic reactant ( $\mathrm{T}-57)$ was used. In areas requiring higher strength, a sodium silicate based grout with an organic reactant (ROC) was used. The viscosity of the grout ranged from 2 to $4 \mathrm{mPa}$-sec. The unconfined compressive strengths of all specimens collected in test pit excavations were above the specified minimum.

No foundation settlement was observed at the structure following the 1989 Loma Prieta earthquake (Graf, 1992a). Based on reported ground surface accelerations (Darragh and Shakal, 1991), this area of San Francisco experienced a peak horizontal acceleration of about $0.15 \mathrm{~g}$. Similar to the Roosevelt School site, this site has yet to be truly tested by large earthquake shaking. 
Table 2.2 - Case Studies of Remediation for Seismic-Induced Settlement and Liquefaction by Permeation Grouting.

\begin{tabular}{|c|c|c|c|c|}
\hline Site & $\begin{array}{c}\text { Site } \\
\text { Characteristics }\end{array}$ & $\begin{array}{l}\text { Reasons for } \\
\text { Method } \\
\text { Selection }\end{array}$ & $\begin{array}{l}\text { Construction } \\
\text { Program }\end{array}$ & Performance \\
\hline $\begin{array}{l}\text { Riverside } \\
\text { Avenue bridge, } \\
\text { Santa Cruz, CA } \\
\text { (Mitchell and } \\
\text { Wentz, 1991). }\end{array}$ & $\begin{array}{l}\text { Loose to medium } \\
\text { dense gravelly } \\
\text { sand. River level } \\
\text { at high tide } 2.7 \mathrm{~m} \\
\text { above bottom of } \\
\text { concrete slab- } \\
\text { apron. }\end{array}$ & $\begin{array}{l}\text { Treatment beneath } \\
\text { existing concrete } \\
\text { noise pier and slab- } \\
\text { apron; limited } \\
\text { working space. }\end{array}$ & $\begin{array}{l}\text { Grout composed of sodium } \\
\text { silicate } \mathrm{N} \text { grade, } \mathrm{MC} 500 \\
\text { micro-fine cement., and less } \\
\text { than } 0.1 \% \text { by volume of } \\
\text { phosphoric acid to control set } \\
\text { time. }\end{array}$ & $\begin{array}{l}\text { No settlement or } \\
\text { detrimental ground } \\
\text { movement reported } \\
\text { after } 1989 \text { Loma } \\
\text { Prieta earthquake; } \\
\mathrm{a}_{\max }=0.45 \mathrm{~g} .\end{array}$ \\
\hline $\begin{array}{l}\text { Roosevelt } \\
\text { Junior High } \\
\text { School, San } \\
\text { Francisco, CA } \\
\text { (Graf and } \\
\text { Zacher, 1979; } \\
\text { Graf, 1992a). }\end{array}$ & $\begin{array}{l}\text { Loose to medium } \\
\text { dense silty sand } \\
\text { and sand extending } \\
\text { to depth of } 4.6 \mathrm{~m} \text {. } \\
\mathrm{N} \text {-values ranged } \\
\text { from } 3 \text { to } 15 \text { before } \\
\text { treatment. }\end{array}$ & $\begin{array}{l}\text { Existing building } \\
\text { and limited } \\
\text { working space. }\end{array}$ & $\begin{array}{l}\text { Sodium silicate based grout } \\
\text { used. Stage down grouting in } \\
0.3 \mathrm{~m} \text { intervals. }\end{array}$ & $\begin{array}{l}\text { Unconfined } \\
\text { compressive strength } \\
\text { ranged from } 269 \mathrm{kPa} \\
\text { to } 879 \mathrm{kPa} \text {. No } \\
\text { settlement reported } \\
\text { after } 1989 \text { Loma } \\
\text { Prieta earthquake; } \\
\text { a } \max \text { about } 0.15 \mathrm{~g} \text {. }\end{array}$ \\
\hline $\begin{array}{l}\text { Concrete } \\
\text { structure } \\
\text { remodeled into } \\
\text { supermarket, } \\
\text { San Francisco, } \\
\text { CA (Graf, } \\
\text { 1992a). }\end{array}$ & Loose clean sand. & Existing building. & $\begin{array}{l}\text { Used sodium silicate based } \\
\text { grout with an inorganic } \\
\text { reactant (T-57) for areas } \\
\text { requiring low strength, and an } \\
\text { organic reactant (ROC) for } \\
\text { areas requiring higher } \\
\text { strength. Stage down } \\
\text { grouting. }\end{array}$ & $\begin{array}{l}\text { Unconfined } \\
\text { compressive strength } \\
\text { above the specified } \\
\text { minimum. No } \\
\text { settlement reported } \\
\text { after } 1989 \text { Loma } \\
\text { Prieta earthquake; } \\
\text { a }_{\max } \text { about } 0.15 \mathrm{~g} .\end{array}$ \\
\hline $\begin{array}{l}\text { Tunnel, San } \\
\text { Francisco, CA } \\
\text { (Hayden and } \\
\text { Baez, 1994). }\end{array}$ & $\begin{array}{l}\text { Loose saturated } \\
\text { soils. }\end{array}$ & $\begin{array}{l}\text { Stabilize soils } \\
\text { during tunnel } \\
\text { construction and } \\
\text { future earthquakes. }\end{array}$ & No data given. & No data given. \\
\hline
\end{tabular}



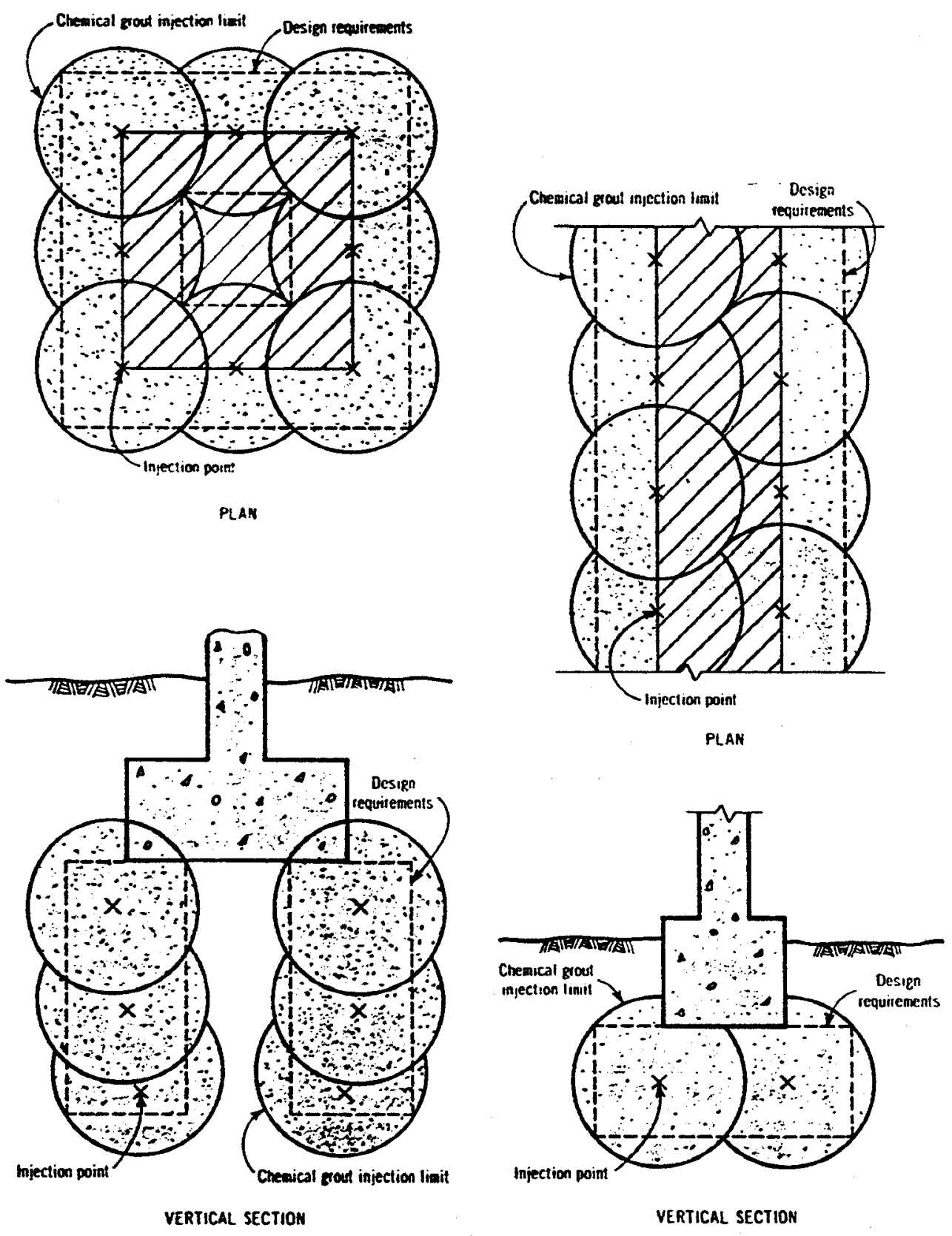

Fig. 2.18 - Contract Drawings Showing Injection Patterns for Permeation Grouting Beneath Existing Spread Footings (Left) and New Wall Footings (Right) at the Roosevelt Junior High School (Graf and Zacher, 1979). 


\subsection{JET GROUTING}

\subsubsection{General}

In jet grouting, high pressure fluid jets are used to erode and mix/replace soil with grout. The general installation procedure begins with the drilling of a small hole, usually 90 to $150 \mathrm{~mm}$ in diameter, to the final depth, as illustrated in Fig. 2.19. Grout is jetted into the soil through small nozzles as the drill rod is rotated and withdrawn. A continuous flow of cuttings from the jet points to the ground surface is required to prevent ground pressures from building up to the jet pressure, leading to ground deformation. The cuttings accumulate at the surface to form large spoil piles. According to Bell (1993), much of the early development of jet grouting took place in Japan and Europe in the 1970s. The technique has been used worldwide to underpin existing foundations, support excavations, control ground water flow, and strengthen liquefiable soils.

The formation of columns by jet grouting is an art, based on experience, semi-empirical relationships, and site trials. The main factors which influence the diameter and strength of jet grouted columns (Bell, 1993; Covil and Skinner, 1994; Stroud, 1994) include:

1. Soil Being Jetted. Sand is easier to erode than clay. Thus, the width of the treated zone will be less in clay than in sands if no adjustments are made during the jetting operation. Irregular column geometries are likely in cobblely soils where larger particles limit the range of jetting, and in highly permeable, poorly graded gravel where grout may flow out of the jetted zone. Soil moisture increases the water content of soil-cement mix, resulting in lower strength.

2. Ground Water Conditions. Grout could be leached out of soil by seepage, or attacked chemically or biologically.

3. Grout Mix. Grout, usually a water-cement mixture, must be matched to ground conditions to sufficiently strengthen and/or reduce permeability. The water-cement ratio of the in situ mix is a key index of strength, initial set time, and durability. Bentonite is usually added where low permeability is critical. Fly ash is added to control excessive bleeding and to improve durability.

4. Jet System. Single, double and triple jet systems are available. The single jet system only uses grout jets for both soil erosion and mixing. In the double jet system, the erosive effect is enhanced by shrouding the grout jet with compressed air. The triple jet system uses water jets shrouded by compressed air for soil erosion, and grout jets located lower down the drill stem for grout placement and mixing. The triple system permits greater flexibility in the control of the final properties of treated ground since the flow rate of the grout can be regulated independently of the erosive air-water jets. On the other hand, more waste cuttings are generated with the triple system than with the single system. 
5. Jet Pressure and Injection Rate. High jet pressures and injection rates can erode soil to great distances. Pressure and nozzle diameter control the grout injection rate and the erosive energy. Typically, jet pressures range between 40 and $60 \mathrm{MPa}$, and nozzle diameters are 2 to $4 \mathrm{~mm}$ in diameter.

6. Drill Rod Rotation and Withdrawal Rates. The amount of grout injected and the degree of mixing depend on the rotation and withdrawal rates of the drill rod. Approximate relationships showing the variation of column diameter, withdrawal (or lift) rate, and jet system for granular materials and for clays are presented in Figs. 2.20 and 2.21, respectively. The effect of jet pressure on column diameter is illustrated in Fig. 2.22.

7. Column Sequencing. A column of grouted soil without sufficient strength may be influenced by the formation of any adjacent columns. Sodium silicate is sometimes added to the grout mix to accelerate the set time.

The number and spacing of grout holes are also important factors contributing to the overall performance of jet grouted soil. Grout holes spaced too far apart will leave zones of ungrouted soil. Zones of poorly grouted soil are possible even with close spacings, as illustrated in Fig. 2.21 .

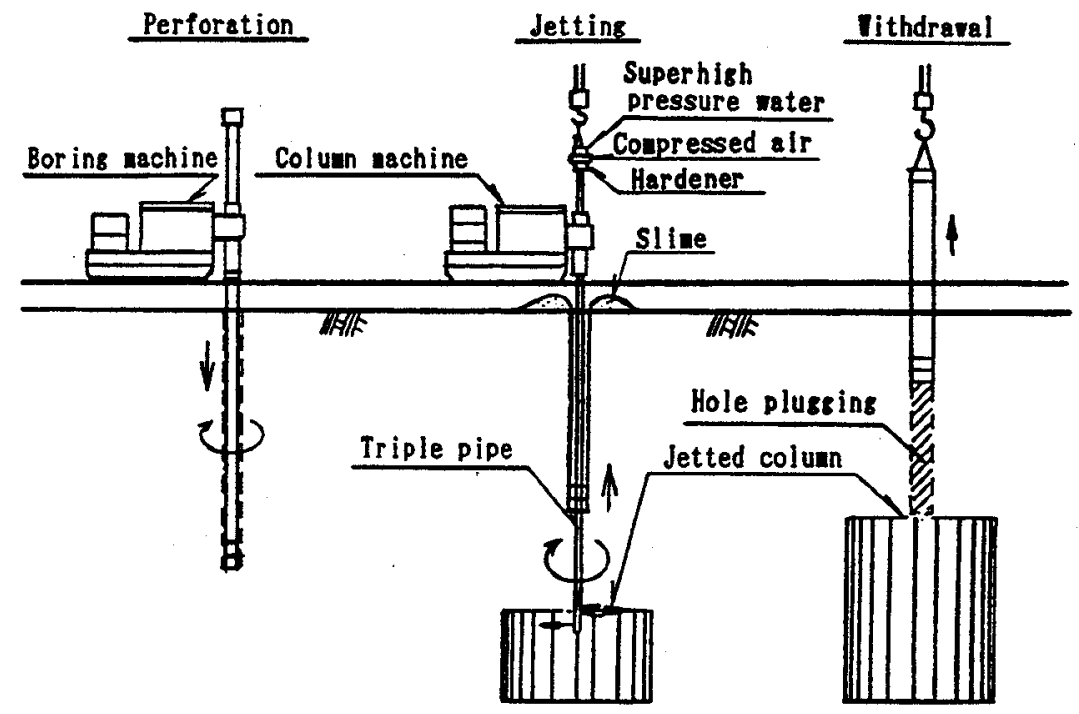

Fig. 2.19 - A Procedure for Jet Grouting (Ichihashi et al., 1992). 
According to Welsh $(1992 ; 1995)$, the cost to mobilize and demobilize jet grouting equipment is over $\$ 35,000$ per rig. The cost of injection labor and grout materials starts at $\$ 320$ per cubic meter of improved ground. This cost does not include handling, removal, and disposal of the large quantities of waste slurry that are produced. Depending on the jet system, the amount of waste slurry produced is $60 \%$ to $100 \%$ of the volume of treated soil.

\subsubsection{Liquefaction Remediation}

There are just a few cases of liquefaction remediation by jet grouting reported in the literature. The little information available for three cases is summarized in Table 2.3. Two of the three cases involved treatment beneath existing structures. In the third case, the site was located in an urban area where low levels of vibration and noise were required. The details for this case are reviewed below.

\subsubsection{Transit Station, Taipei, Taiwan}

A new transit station was planned in the city of Taipei (Tsai et al., 1993). As described by Tsai et al. (1993), the upper $2 \mathrm{~m}$ of soil at the proposed site were composed of fill characterized by a $\mathrm{N}$-value of 8 . The fill was underlain by $4 \mathrm{~m}$ of andesite debris consisting of sandy gravel and cobbles, and characterized by SPT blow counts, N, ranging from 54 to over 100 . The andesite debris was underlain by $2 \mathrm{~m}$ of silty clay characterized by a $\mathrm{N}$-value of 2 . The silty clay was underlain by $18 \mathrm{~m}$ of silty sand with occasional andesite debris characterized by $\mathrm{N}$-values ranging from 3 to over 100 . The water table was at a depth of $4 \mathrm{~m}$. It was determined that the upper part of the silty sand layer which exhibited low $\mathrm{N}$-values would liquefy during the maximum credible earthquake.

From the report of Tsai et al. (1993), jet grouting was used to construct soil-cement columns to a depth of $14 \mathrm{~m}$, spaced $2 \mathrm{~m}$ apart over an area of $17 \mathrm{~m}$ by $48 \mathrm{~m}$. Cores taken from the center of the initial columns did not contain cement grout. To remedy the problem, grout pressures and drill rod withdrawal rates were adjusted based on the soil type encountered, and sodium silicate was added to the grout mix to accelerate the set time. In the loose sand, grout pressures ranged from 16 to $18 \mathrm{MPa}$ and withdrawal rate was set at $190 \mathrm{~mm} / \mathrm{min}$. In the clayey soils and medium dense sands, grout pressures ranged from 18 to $20 \mathrm{MPa}$. Cores taken from columns constructed by the modified procedures exhibited a minimum 28 days unconfined compressive strength of $1.4 \mathrm{MPa}$. 


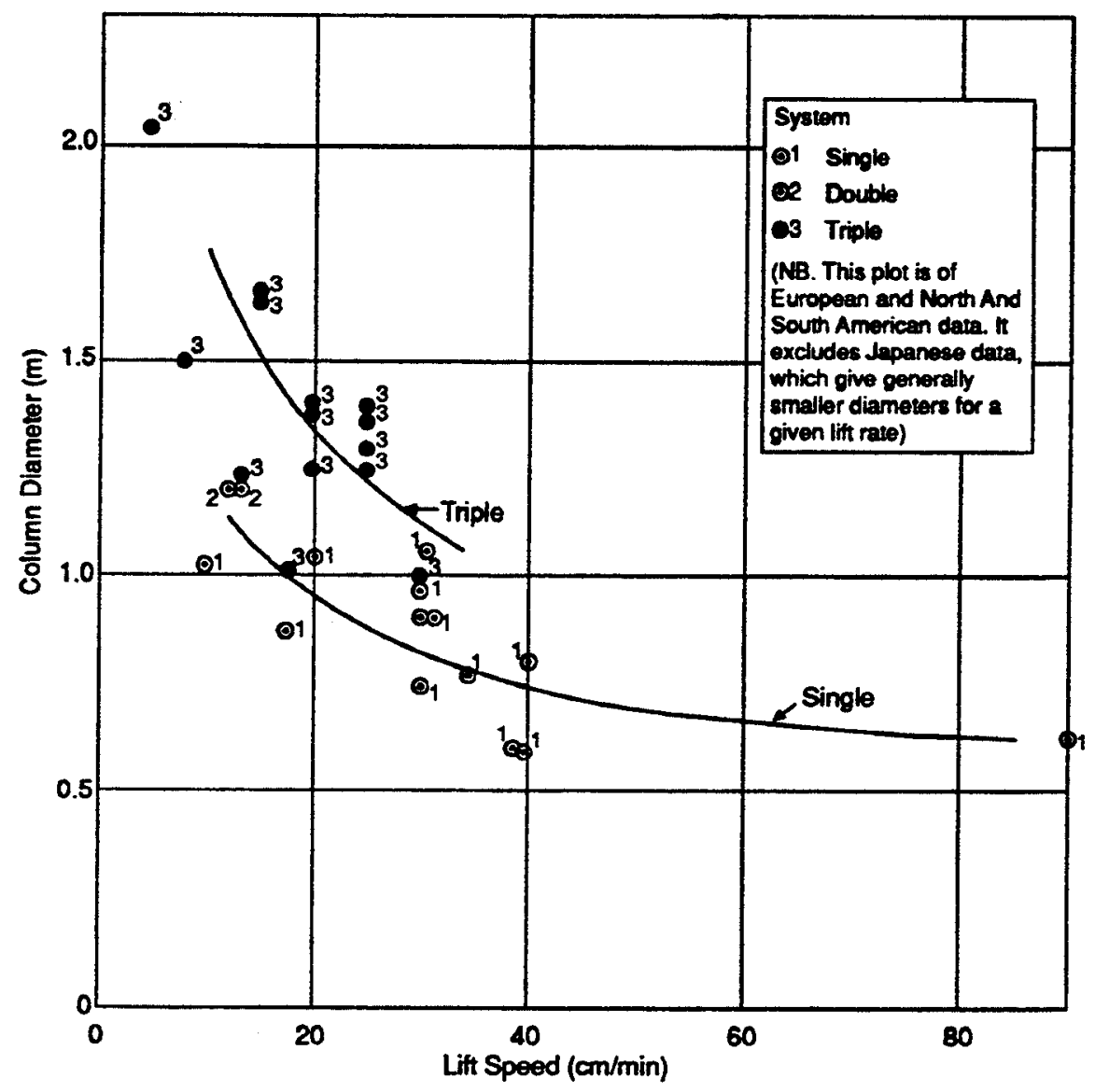

Fig. 2.20 - Variation in Diameter of Jet Grouted Column with Lift Rate in Sands (Stroud, 1994). 


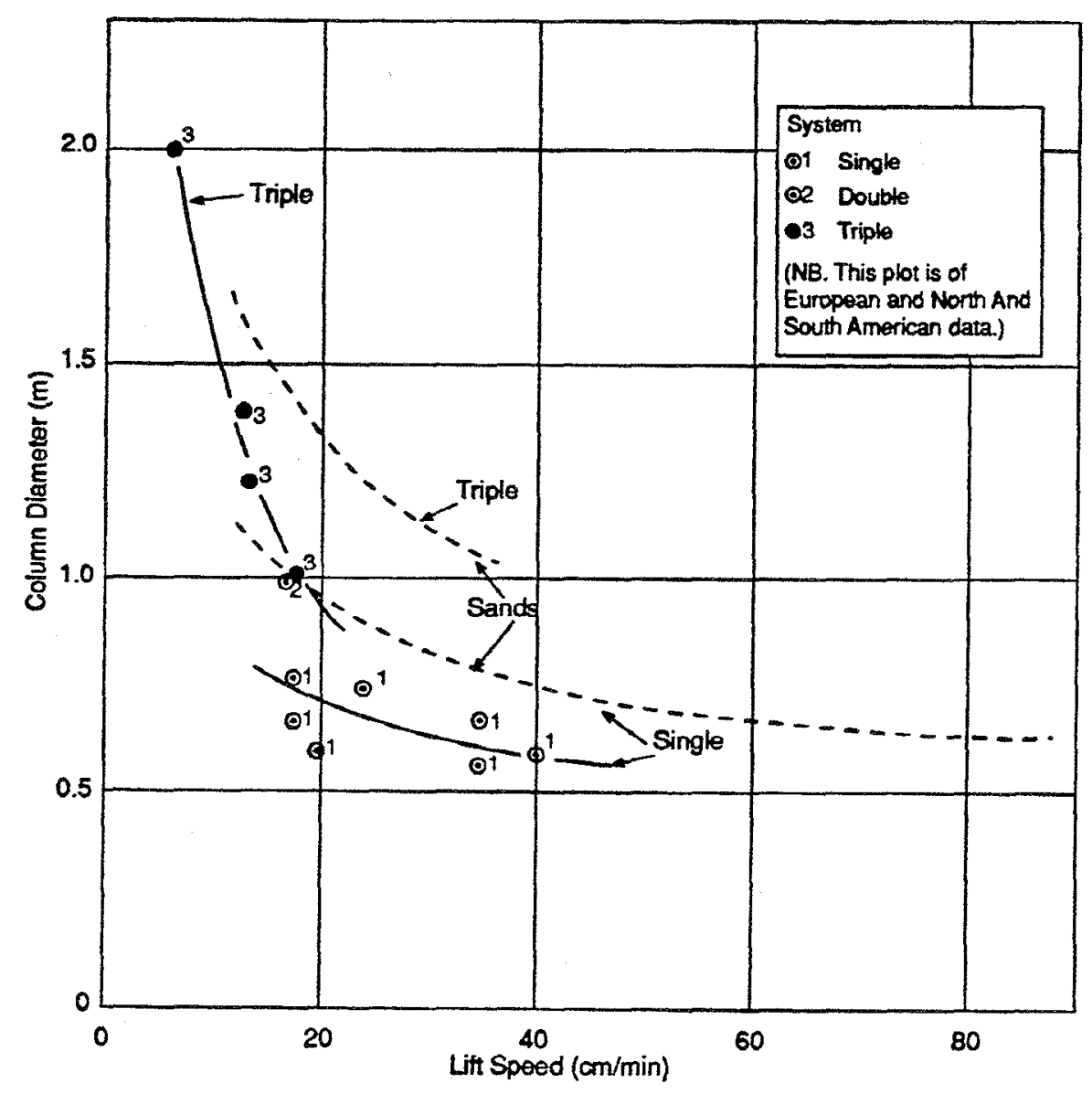

Fig. 2.21 - Variation in Diameter of Jet Grouted Column with Lift Rate in Clays (Solid Curves). The Relationships for Sands (Dashed Curves) are Shown for Comparison (Stroud, 1994). 


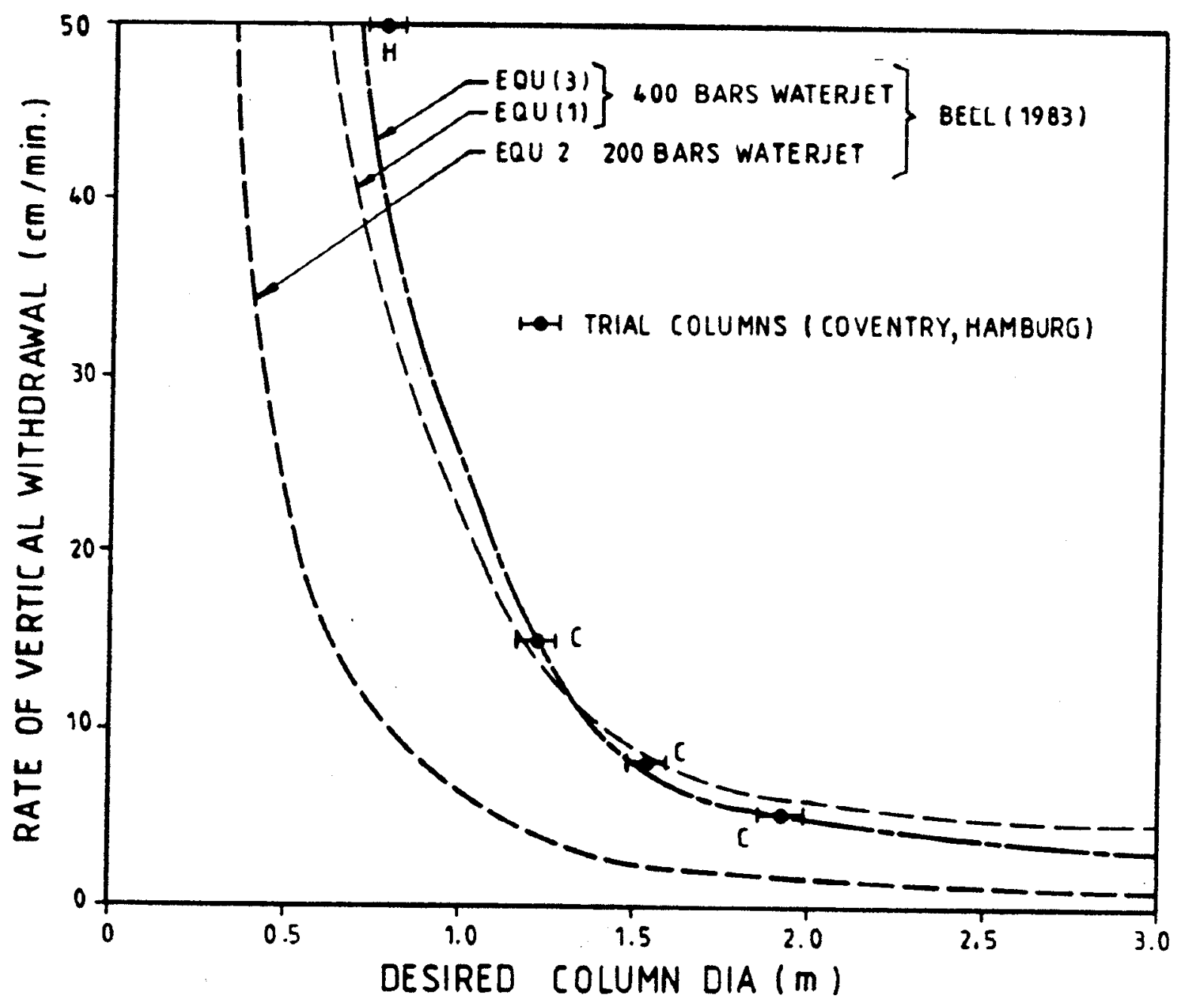

Fig. 2.22 - Variation in Diameter of Jet Grouted Column with Lift Rate Showing Effect of Jet Pressure (Bell, 1993). (1 bar =0.1 MPa.) 

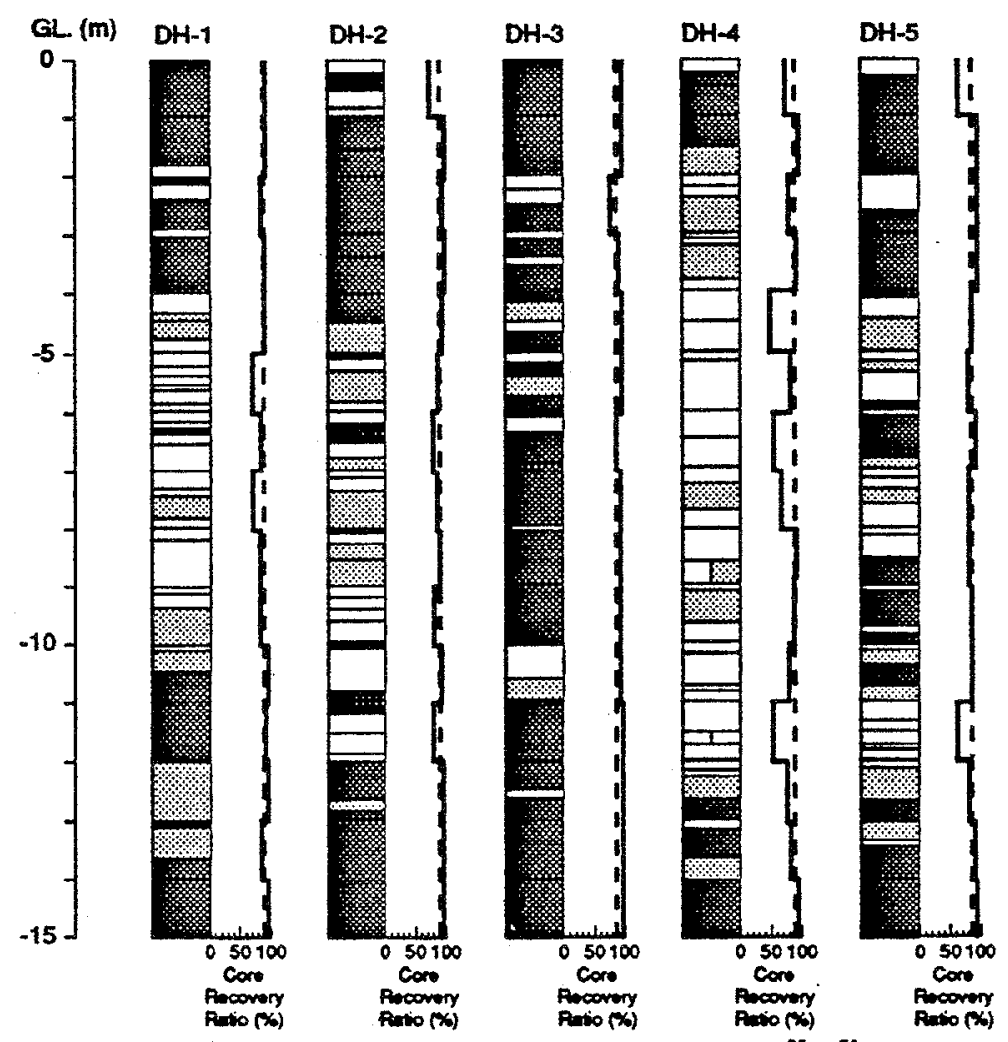

Legend:

GOOD FAIR $\square$ POOR

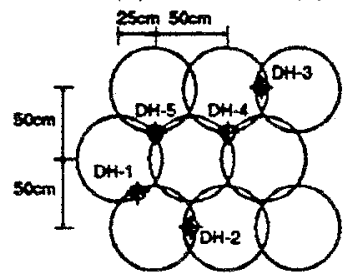

Fig. 2.23 - Quality and Percent Recovery of Jet Grouted Soil in Cores Midway between Grout Injection Positions (from Stroud, 1994). Coring and Testing were Part of a Soil Improvement Project in Soft Clay for Support of a 12-m-deep Excavation (Liao et al., 1994). Jet Grouting was Performed using Grout Injection Pressure of 18 to 20 $\mathrm{MPa}$, with Drill Rod Rotation and Lift Rates of 15 r.p.m. and $188 \mathrm{~mm} / \mathrm{min}$, Respectively. While Only $40 \%$ of the Core Samples were Well Grouted (Average 28 Days Unconfined Compressive Strength of About 3.5 MPa), Movements Measured During Excavation were Acceptably Low. 
Table 2.3 - Case Histories of Liquefaction Remediation by Jet Grouting.

\begin{tabular}{|c|c|c|c|c|}
\hline Site & $\begin{array}{c}\text { Site } \\
\text { Characteristics }\end{array}$ & $\begin{array}{l}\text { Reasons for } \\
\text { Method } \\
\text { Selection }\end{array}$ & $\begin{array}{l}\text { Construction } \\
\text { Program }\end{array}$ & Performance \\
\hline $\begin{array}{l}\text { Building, } \\
\text { Charleston, SC } \\
\text { (Welsh and } \\
\text { Burke, 1991). }\end{array}$ & $\begin{array}{l}\text { Liquefiable fine } \\
\text { sand. }\end{array}$ & $\begin{array}{l}\text { Existing building } \\
\text { and limited work } \\
\text { space. }\end{array}$ & $\begin{array}{l}\text { Confine liquefiable sand with } \\
\text { series of overlapping soil- } \\
\text { cement columns around } \\
\text { perimeter of the spread } \\
\text { footings. }\end{array}$ & No data given. \\
\hline $\begin{array}{l}\text { Power plant } \\
\text { structure, } \\
\text { Sacramento, } \\
\text { CA (Hayden } \\
\text { and Baez, } \\
\text { 1994). }\end{array}$ & $\begin{array}{l}\text { Decaying timber } \\
\text { pile foundation in } \\
\text { loose sands and } \\
\text { silty sands. }\end{array}$ & Existing building. & $\begin{array}{l}\text { Encapsulate pile foundation } \\
\text { to prevent foundation } \\
\text { settlement and liquefaction } \\
\text { damage by jet grouting to } \\
\text { depths of } 13.7 \mathrm{~m} \text {. }\end{array}$ & No data given. \\
\hline $\begin{array}{l}\text { Transit station, } \\
\text { Taipei, Taiwan } \\
\text { (Tsai et al., } \\
\text { 1993). }\end{array}$ & $\begin{array}{l}\text { Dense gravelly } \\
\text { layer between } \\
\text { depths of } 2 \text { and } 6 \\
\mathrm{~m} \text {. Loose to } \\
\text { medium dense silty } \\
\text { sand between } 8 \\
\text { and } 26 \mathrm{~m} \text {. }\end{array}$ & $\begin{array}{l}\text { Site } 30 \mathrm{~m} \text { from } \\
\text { residential } \\
\text { buildings. }\end{array}$ & $\begin{array}{l}\text { Soil-cement-sodium silicate } \\
\text { columns } 14 \mathrm{~m} \text { in depth, } \\
\text { spaced } 2 \mathrm{~m} \text { apart. Grout } \\
\text { pressures ranged from } 16 \text { to } \\
18 \mathrm{MPa} \text { in loose sands, and } \\
18 \text { to } 20 \mathrm{MPa} \text { in clayey soils } \\
\text { and medium dense sands. } \\
\text { Withdrawal rate of } 190 \\
\mathrm{~mm} / \mathrm{min} \text {. in loose soil. }\end{array}$ & $\begin{array}{l}\text { Cores taken from } \\
\text { center of columns } \\
\text { met the minimum } 28 \\
\text { days unconfined } \\
\text { compressive strength } \\
\text { requirement of } 1.4 \\
\mathrm{MPa} \text {. }\end{array}$ \\
\hline
\end{tabular}




\subsection{IN SITU SOIL MIXING}

\subsubsection{General}

In situ soil mixing is the mechanical mixing of soil and stabilizer using rotating auger and mixing-bar arrangements. A conceptual drawing of the in situ soil mixing process is shown in Fig. 2.24. As augers penetrate the ground, the stabilizer is pumped through the auger shaft and out the tip. Flat mixing bars attached to the auger shaft mix injected stabilizer and soil. Upon reaching the designed depth, a second mixing occurs as augers are withdrawn. The result is high strength or low permeability columns and panels. Multiple columns and panels are commonly layout in a pattern, such as those illustrated in Fig. 2.25. According to Broomhead and Jasperse (1992), much of the development of in situ soil mixing occurred in Japan during the past 20 years. It has been successfully used to control ground water flow, support excavations, stabilize embankments and slopes, increase bearing capacity for new foundations, and prevent liquefaction-induced ground displacement.

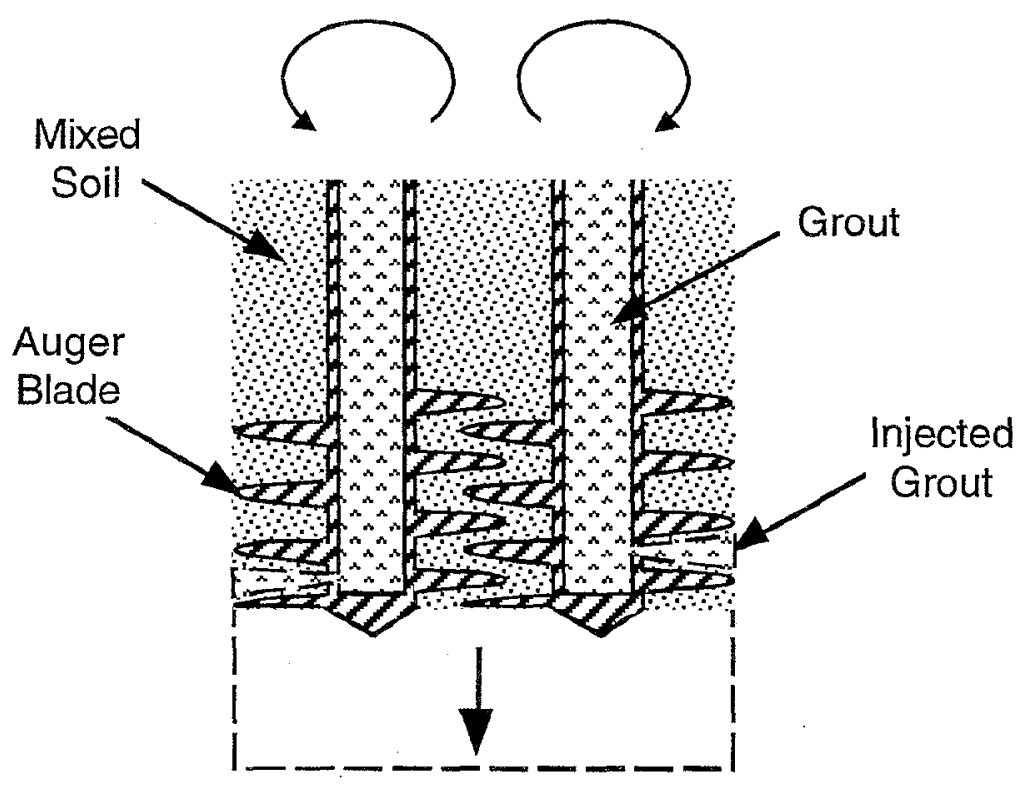

Fig. 2.24 - Conceptual Drawing of the In Situ Soil Mixing Technique. 
The main factors which influence the effectiveness of in situ soil mixing (Stroud, 1994; Taki and Yang, 1991; JSSFME, 1995) include:

1. Soil Being Mixed. Boulders, logs, and hard strata can make mixing impossible. Soil moisture increases water content of the soil-cement mix, resulting in lower strengths.

2. Ground Water Conditions. Stabilizer could be leached out of soil by seepage, or attacked chemically or biologically.

3. Stabilizer. Cement is the primary agent for solidification. The water-cement ratio is an important index for strength, initial set time, and durability. Bentonite is added to increase workability and where low permeability is critical. Additives such as silicate, slag, and gypsum have been used for gaining strength in saline and organic soils. Retarding agents which extend set time have been used to make lap work easier.

4. Mixing Equipment. The maximum possible treatment depth depends on auger size, number of augers, and torque capacity. Large augers (up to $4 \mathrm{~m}$ in diameter) require more torque, and are generally limited to depths less than about $8 \mathrm{~m}$. For deeper mixing, a singlerow of two to four auger shafts about $1 \mathrm{~m}$ in diameter is typically used.

5. Grout Injection Volume. Large volumes of stabilizer injected into the soil may cause ground to heave.

6. Auger Rotation, Descent and Withdrawal Rates. Slow auger rotation, descent and withdrawal rates increase consistency of soil mix.

7. Mixing Sequence. It is easier to lap adjacent columns before the first column hardens.

8. Soil Improvement Pattern. The features of various improvement patterns or types are summarized in Table 2.4 .

The improved ground is considered an underground structure having greater rigidity than the surrounding soil. Fujii et al. (1992) and JSSFME (1995) identify the forces imposed during earthquake loading. Babasaki et al. (1991) outline a seismic design procedure for improved foundations.

According to Welsh (1995), it is very expensive to mobilize and demobilize a large multi-auger rigs since there are just a few available in the United States. The approximate cost is $\$ 100,000$ per rig and grout plant. The cost of grout materials and mixing starts at about $\$ 100$ per cubic meter of improved ground for shallow mixing (say depths less than $8 \mathrm{~m}$ ), and $\$ 200$ per cubic meter for deep mixing (say depths between 8 and $30 \mathrm{~m}$ ). The waste soil-cement produced during augering is about $30 \%$ of the treated volume. 


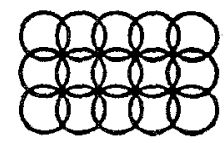

Block

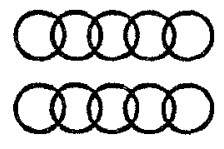

Wall

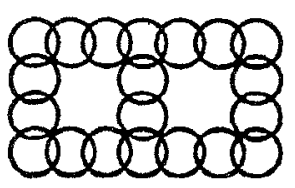

Lattice

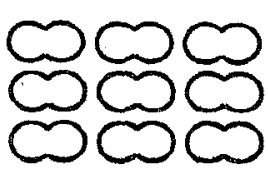

Pile

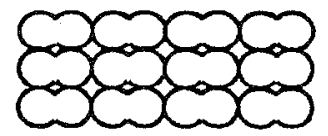

Tangent Circle Block

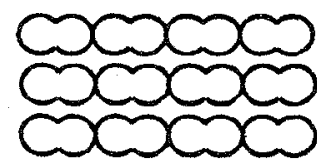

Tangent Circle Wall

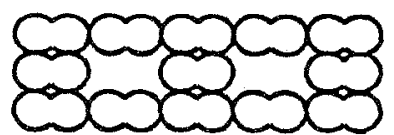

Tangent Circle Lattice

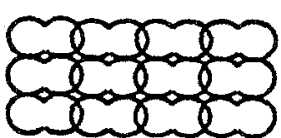

Tangent Circle Lapping Block

Fig. 2.25 - Various Improvement Patterns or Types of In Situ Soil Mixing (JSSFME, 1995).

\subsubsection{Liquefaction Remediation}

Five liquefaction remediation projects using in situ soil mixing are summarized in Table 2.5. These projects involved treatment at either new construction or existing embankment sites. The primary function of the improved ground in all five cases was to control liquefaction-induced ground movement. The details available for three of these cases are reviewed as follows.

\subsubsection{Jackson Lake Dam, Wyoming}

The initial Jackson Lake Dam in the Grand Teton National Park, Wyoming, was a uncompacted hydraulic fill structure built in the early 1900s. As described by Ryan and Jasperse (1989), the dam was founded on interbedded layers of loose gravel and sand with occasional silt and clay layers to a depth of $30 \mathrm{~m}$. The U.S. Bureau of Reclamation determined that the loose embankment and foundation soils were susceptible to liquefaction under strong earthquake shaking. 
Remedial work involved replacement of the dam and treatment of the foundation by the dynamic compaction and in situ soil mixing techniques (Ryan and Jasperse, 1989; Taki and Yang, 1991). Dynamic compaction was used to densify foundation soils to a depth of about 11 $\mathrm{m}$ where the center of the new dam would be. In situ soil mixing was used to treat foundation soils to a depth of $33 \mathrm{~m}$ where the upstream and downstream toes of the dam would be, as shown in Fig. 2.26. The work was performed during 1987 and 1988, and included the construction of overlapping soil-cement panels arranged to form hexagonal cells as well as an upstream cutoff wall. A plan view of the upstream improvement is illustrated in Fig. 2.27. The purpose of the hexagonal cells was to contain the loose sand and gravel in the event of liquefaction, thereby preventing ground movement and failure of the embankment slopes. A two-shaft soil mixing auger was used to construct the hexagonal cells. The diameter of each shaft was $0.9 \mathrm{~m}$. The final grout mix design had a water-cement ratio of 1.25:1 by weight. The cement content per cubic meter of treated soil was about $337 \mathrm{~kg}$. According to Taki and Yang, the 28 days unconfined compressive strength of core specimens ranged from 1.4 to $8 \mathrm{MPa}$.

\subsubsection{Pulp and Paper Mill Spill Tanks, British Columbia}

The construction of two large spill tanks was planned at a pulp and paper mill near Vancouver, British Columbia. A typical cross section of the site is shown in Fig. 2.28. As described by Broomhead and Jasperse (1992), the site was capped by a layer of desiccated, very stiff sand and silt fill, designated as crust. The crust, about $1.8 \mathrm{~m}$ thick, exhibited lower stiffness with depth. The crust was underlain by about $3.7 \mathrm{~m}$ of loose sand and silt fill containing $7 \%$ to $60 \%$ fines (silt and clay). The fill was underlain by about $1.2 \mathrm{~m}$ of medium dense beach sand. The beach sand was underlain by dense silt. At the site, the water table was at an average depth of $3 \mathrm{~m}$. It was determined that the loose fill would liquefy under the design event, and cause as much as $0.3 \mathrm{~m}$ of lateral movement.

To prevent liquefaction-induced ground movement, a continuous ring of tangent soilcement columns was constructed around the perimeter of each tanks, as shown in Fig. 2.29. Each column was extended $0.9 \mathrm{~m}$ into the dense silt. A single shaft auger, $3.6 \mathrm{~m}$ in diameter, was used to construct the columns. Broomhead and Jasperse (1992) reported that the basic mix design was $177 \mathrm{~kg}$ of cement per cubic meter of treated soil. The injected grout had a watercement ratio of $1.8: 1$ by weight. The 28 days unconfined compressive strength of core specimens ranged from about 1 to $2.5 \mathrm{MPa}$.

To dissipate any excess pore water pressures which might be generated during strong ground shaking, the floor slab of each tanks was placed on top of a gravel drain blanket. The drain blanket was connected to cross drains that were spaced at regular intervals and passed beneath the wall footing. 


\subsubsection{Office Building ("Building N"), Japan}

A new office building was planned in Kagoshima City, Japan (Babasaki et al., 1991). The upper $5 \mathrm{~m}$ of foundation soil were composed of sand with pumice and gravel, and less than about $15 \%$ fines. The gravelly sand layer was underlain by about $15 \mathrm{~m}$ of fine sand with $25 \%$ to $55 \%$ fines. SPT blow counts measured in the upper $20 \mathrm{~m}$ of soil were less than 10 . The water table was within a meter of the ground surface. It was determined that liquefaction was possible down to a depth of $12.5 \mathrm{~m}$.

As reported by Babasaki et al. (1991), in situ soil mixing was used to improve foundation soil conditions to a depth of $13.5 \mathrm{~m}$, as illustrated in Fig. 2.30. The design was verified through finite element numerical analysis and centrifuge model tests. Base on the results of a pilot study conducted at the site, it was concluded that $300 \mathrm{~kg}$ of cement were required per cubic meter in the gravelly sand and $200 \mathrm{~kg}$ were required per cubic meter in the silt sand to achieve the design standard unconfined compressive strength of $2 \mathrm{MPa}$. The machine used in the pilot study and during construction consisted of 3 auger shafts, each shaft having a diameter of $0.7 \mathrm{~m}$. The rate of auger descent was set at $0.5 \mathrm{~m} / \mathrm{min}$. The rate of auger withdrawal was set at $0.5 \mathrm{~m} / \mathrm{min}$ in the gravelly sand, and $1.0 \mathrm{~m} / \mathrm{min}$ in the silty sand. The rate of auger rotation was set at 25 r.p.m. Grout was injected during auger descent. The specified grout mix for the gravelly sand had a water-cement-bentonite ratio of 0.7:1:0.03 by weight. The grout mix for the silt sand had more water, with a water-cement-bentonite ratio of 1:1:0.05 by weight. 
Table 2.4 - Features of Various Improvement Types of In Situ Soil Mixing (JSSFME, 1995).

\begin{tabular}{|c|c|c|c|c|}
\hline Types & Stability & Economy & Installation & Features in Work \\
\hline Block & $\begin{array}{l}\text { The improvement } \\
\text { resists external forces } \\
\text { as one body. High } \\
\text { stability is provided } \\
\text { overall and also } \\
\text { internally. }\end{array}$ & $\begin{array}{l}\text { Improved volume is } \\
\text { larger than other } \\
\text { improvement types. }\end{array}$ & $\begin{array}{l}\text { All piles overlap, and a } \\
\text { long work period is } \\
\text { needed. }\end{array}$ & $\begin{array}{l}\text { Improvement area is } \\
\text { decided using a design } \\
\text { method similar to that } \\
\text { for gravity } \\
\text { construction. }\end{array}$ \\
\hline Wall & $\begin{array}{l}\text { Each improved wall is } \\
\text { well joined together, } \\
\text { resulting in high } \\
\text { stability when } \\
\text { resisting as a single } \\
\text { body. }\end{array}$ & $\begin{array}{l}\text { Smaller improved } \\
\text { volume and lower cost } \\
\text { than block type. }\end{array}$ & $\begin{array}{l}\text { Precise control is } \\
\text { needed for adequate } \\
\text { lapping of long units } \\
\text { and short units. }\end{array}$ & $\begin{array}{l}\text { Consideration of } \\
\text { unimproved soil } \\
\text { between walls is } \\
\text { necessary. } \\
\text { Improvement area } \\
\text { depends on internal } \\
\text { stability. }\end{array}$ \\
\hline Lattice & $\begin{array}{l}\text { Stability as a whole is } \\
\text { the same as with the } \\
\text { block type. }\end{array}$ & $\begin{array}{l}\text { Intermediate between } \\
\text { block type and wall } \\
\text { type. }\end{array}$ & $\begin{array}{l}\text { Lattice type } \\
\text { improvement needs } \\
\text { difficult work } \\
\text { procedure. }\end{array}$ & $\begin{array}{l}\text { Three-dimensional } \\
\text { analysis of internal } \\
\text { stress is required. }\end{array}$ \\
\hline Pile & $\begin{array}{l}\text { Stable when horizontal } \\
\text { force is not large. }\end{array}$ & $\begin{array}{l}\text { Economical because of } \\
\text { shorter work period } \\
\text { and less improvement } \\
\text { volume. }\end{array}$ & $\begin{array}{l}\text { No need for lapping } \\
\text { control. }\end{array}$ & $\begin{array}{l}\text { In addition to total } \\
\text { stability analysis, } \\
\text { analysis of the stresses } \\
\text { in each pile is } \\
\text { occasionally } \\
\text { necessary. }\end{array}$ \\
\hline $\begin{array}{l}\text { Tangent } \\
\text { Circle }\end{array}$ & $\begin{array}{l}\text { Stable when horizontal } \\
\text { force is not large. } \\
\text { Column rows in a } \\
\text { direction of major } \\
\text { external force may be } \\
\text { overlapped to increase } \\
\text { stability (tangent } \\
\text { circle-lapping } \\
\text { improvement). }\end{array}$ & $\begin{array}{l}\text { Economical compared } \\
\text { with block type. }\end{array}$ & $\begin{array}{l}\text { Precise control is } \\
\text { needed for ensuring } \\
\text { positive contact } \\
\text { between the circles. } \\
\text { The work period is } \\
\text { longer for the lapped } \\
\text { tangent circle than for } \\
\text { the tangent circle type. }\end{array}$ & $\begin{array}{l}\text { Both a total system } \\
\text { stability analysis and } \\
\text { an individual pile body } \\
\text { analysis are necessary. }\end{array}$ \\
\hline
\end{tabular}


Table 2.5 - Case Studies of Liquefaction Remediation by In Situ Soil Mixing.

\begin{tabular}{|c|c|c|c|c|}
\hline Site & $\begin{array}{c}\text { Site } \\
\text { Characteristics }\end{array}$ & $\begin{array}{l}\text { Reasons for } \\
\text { Method } \\
\text { Selection }\end{array}$ & $\begin{array}{l}\text { Construction } \\
\text { Program }\end{array}$ & Performance \\
\hline $\begin{array}{l}\text { Jackson Lake } \\
\text { Dam, WY } \\
\text { (Ryan and } \\
\text { Jasperse, 1989; } \\
\text { Taki and Yang, } \\
\text { 1991). }\end{array}$ & $\begin{array}{l}\text { Loose gravel and } \\
\text { sand extending to } \\
\text { depths of } 30 \mathrm{~m} \text {. }\end{array}$ & $\begin{array}{l}\text { Simpler quality } \\
\text { control program } \\
\text { than other methods. } \\
\text { Not affected by } \\
\text { artesian pressures. }\end{array}$ & $\begin{array}{l}\text { Where upstream and } \\
\text { downstream slopes of the new } \\
\text { dam would be, soil mixed } \\
\text { panels forming open } \\
\text { hexagonal cells with } 15 \mathrm{~m} \\
\text { sides extending to a depth of } \\
33 \mathrm{~m} \text {. A two-shaft auger was } \\
\text { used. Shaft diameter was } 0.9 \\
\mathrm{~m} \text {. Grout had a water-cement } \\
\text { ratio of } 1.25: 1 \text { by weight. } \\
\text { Mixed soil contained } 337 \mathrm{~kg} \\
\text { of cement per } \mathrm{m}^{3} \text {. }\end{array}$ & $\begin{array}{l}\text { Unconfined } \\
\text { compressive strength } \\
\text { of core specimens } \\
\text { ranged from } 1.4 \text { to } 8 \\
\text { MPa. }\end{array}$ \\
\hline $\begin{array}{l}\text { Spill tanks at } \\
\text { pulp and paper } \\
\text { mill, } \\
\text { Vancouver, BC } \\
\text { (Broomhead } \\
\text { and Jasperse, } \\
\text { 1992). }\end{array}$ & $\begin{array}{l}\text { Loose sand-silt fill } \\
\text { between depths of } \\
1.8 \text { and } 5.5 \mathrm{~m} \text {. The } \\
\text { fill is underlain by } \\
1.2 \mathrm{~m} \text { of medium } \\
\text { dense beach sand. }\end{array}$ & $\begin{array}{l}\text { Provided optimal } \\
\text { "cost-benefit" } \\
\text { solution. }\end{array}$ & $\begin{array}{l}\text { Tank constructed on ring of } \\
\text { tangent columns extending } \\
0.9 \mathrm{~m} \text { into dense silt. A } \\
\text { single } 3.6-\mathrm{m} \text {-diameter shaft } \\
\text { auger was used. Grout had a } \\
\text { water-cement ratio of } 1.8: 1 \text { by } \\
\text { weight. Mixed soil contained } \\
177 \mathrm{~kg} \text { of cement per } \mathrm{m}^{3} \text {. }\end{array}$ & $\begin{array}{l}\text { Unconfined } \\
\text { compressive strength } \\
\text { of core specimens } \\
\text { ranged from } 1 \text { to } 3 \\
\mathrm{MPa} \text {. }\end{array}$ \\
\hline $\begin{array}{l}\text { Office building } \\
\text { ("Building N"), } \\
\text { Kagoshima, } \\
\text { Japan } \\
\text { (Babasaki et } \\
\text { al., 1991). }\end{array}$ & $\begin{array}{l}\text { Loose sand with } \\
\text { pumice and gravel, } \\
\text { and fine sand } \\
\text { extending to } 13.5 \\
\text { m. N-values less } \\
\text { than } 8 \text {. }\end{array}$ & $\begin{array}{l}\text { Small urban } \\
\text { construction site } \\
\text { with adjacent } \\
\text { buildings. }\end{array}$ & $\begin{array}{l}\text { Soil mixed panels forming } 5 \\
\mathrm{~m} \times 5 \mathrm{~m} \text { open cells extending } \\
\text { to a depth of } 13.5 \mathrm{~m} \text {. A } 3- \\
\text { shaft auger was used. Shaft } \\
\text { diameter was } 0.7 \mathrm{~m} \text {. Descent } \\
\text { and lift rates were } 0.5 \text { to } 1.0 \\
\mathrm{~m} / \mathrm{min} \text {. Rotation rate was } 25 \\
\text { r.p.m. Grout had a water- } \\
\text { cement-bentonite ratio of } \\
0.7: 1: 0.03 \text { to } 1: 1: 0.05 \text {. Mixed } \\
\text { soil contained } 300 \text { to } 200 \mathrm{~kg} \\
\text { of cement per } \mathrm{m}^{3} \text {. }\end{array}$ & $\begin{array}{l}\text { Design standard } \\
\text { unconfined } \\
\text { compressive strength } \\
\text { of } 2 \mathrm{MPa} \text {. }\end{array}$ \\
\hline $\begin{array}{l}\text { Arakawa River } \\
\text { embankment, } \\
\text { Japan } \\
\text { (JSSFME, } \\
\text { 1995). }\end{array}$ & $\begin{array}{l}\text { Loose sand } 3 \text { to } 6 \\
\mathrm{~m} \text { thick, underlain } \\
\text { by soft silt and clay } \\
18 \text { to } 21 \mathrm{~m} \text { thick. }\end{array}$ & $\begin{array}{l}\text { Existing } \\
\text { embankment. } \\
\text { Lattice chosen over } \\
\text { block to minimize } \\
\text { cost. }\end{array}$ & $\begin{array}{l}\text { Soil mixed panels forming } 5 \\
\mathrm{~m} \times 10 \mathrm{~m} \text { dense cells } \\
\text { extending to dense soil } 24 \mathrm{~m} \\
\text { below river level. A two- } \\
\text { shaft auger was used. Shaft } \\
\text { diameter was } 0.9 \mathrm{~m}\end{array}$ & No data given. \\
\hline $\begin{array}{l}\text { Shinano River } \\
\text { embankment, } \\
\text { Niigata, Japan } \\
\text { (Fujii et al., } \\
\text { 1992; Koga et } \\
\text { al., 1993). }\end{array}$ & $\begin{array}{l}\text { Loose sands and } \\
\text { silts } 12 \text { to } 13 \mathrm{~m} \\
\text { thick. }\end{array}$ & $\begin{array}{l}\text { Existing } \\
\text { embankment and } \\
\text { nearby railway. } \\
\text { Lattice chosen over } \\
\text { block to minimize } \\
\text { cost. }\end{array}$ & $\begin{array}{l}\text { Soil mixed panels forming } \\
5 \mathrm{~m} \times 5.7 \mathrm{~m} \text { open cells } \\
\text { extending to a depth of } 14.4 \\
\mathrm{~m} \text {. A two-shaft auger was } \\
\text { used. Shaft diameter was } 0.9 \\
\mathrm{~m} \text {. }\end{array}$ & No data given. \\
\hline
\end{tabular}




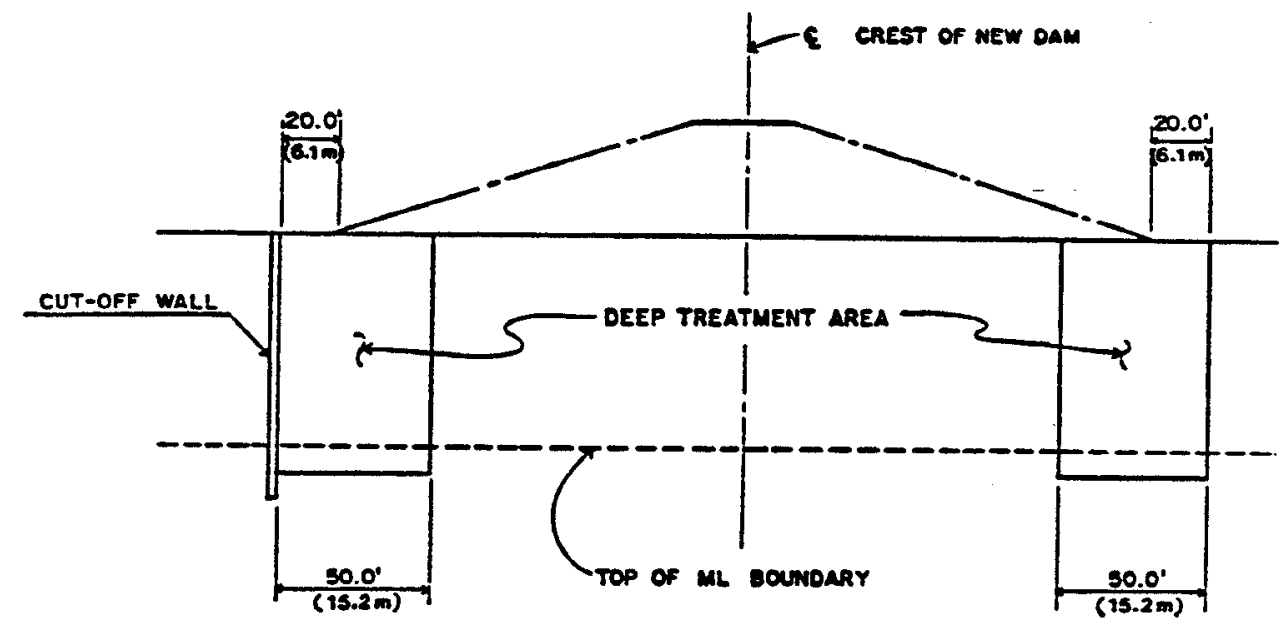

Fig. 2.26 - Simplified Cross Section of the New Jackson Lake Dam Showing Areas of Deep Treatment by In Situ Soil Mixing (Ryan and Jasperse, 1989).

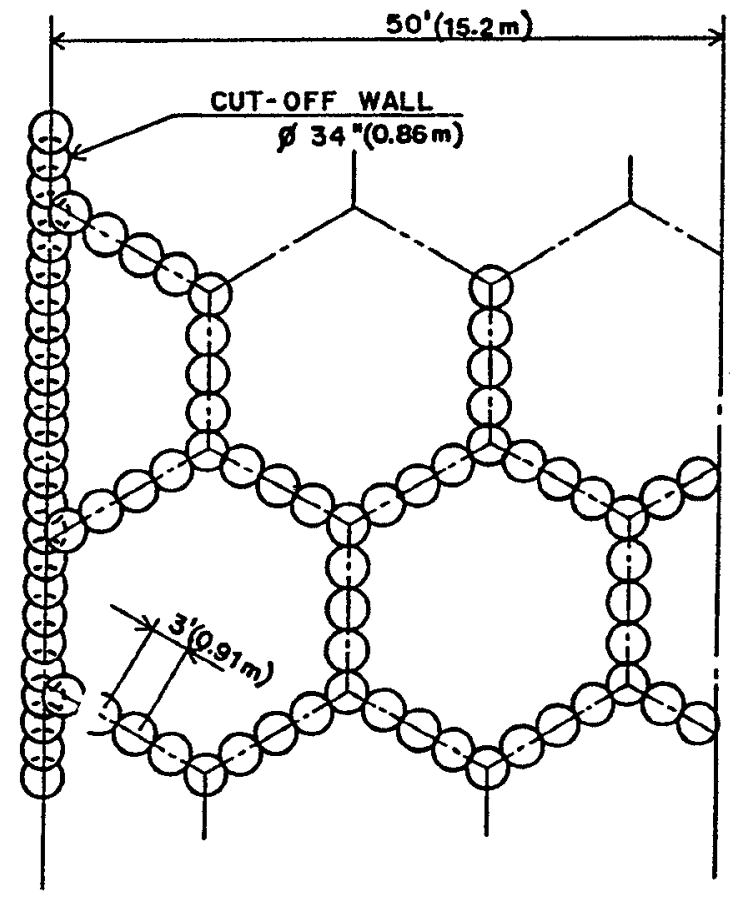

Fig. 2.27 - Plan View of Soil Improvement Pattern in the Deep Treatment Areas at Jackson Lake Dam (Ryan and Jasperse, 1989). 


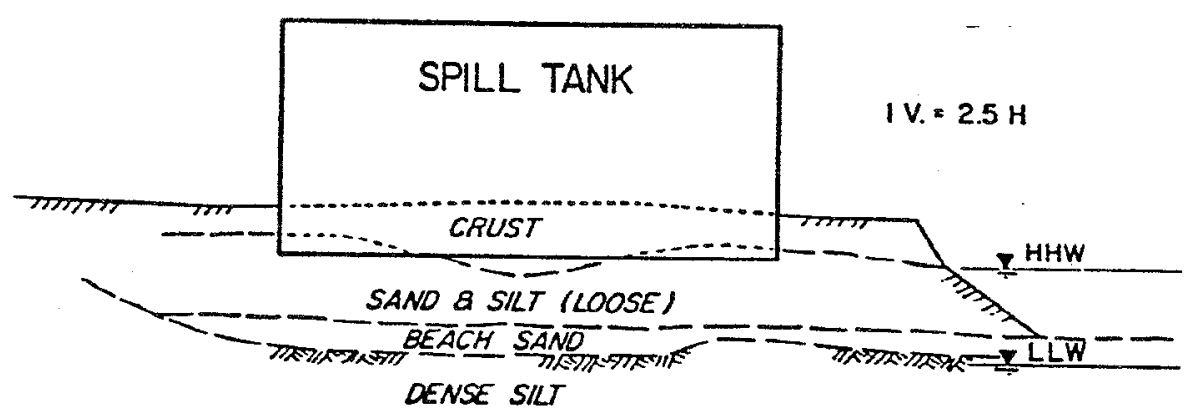

Fig. 2.28 - Typical Cross Section of the Pulp and Paper Mill Spill Tank Site (Broomhead and Jasperse, 1992).

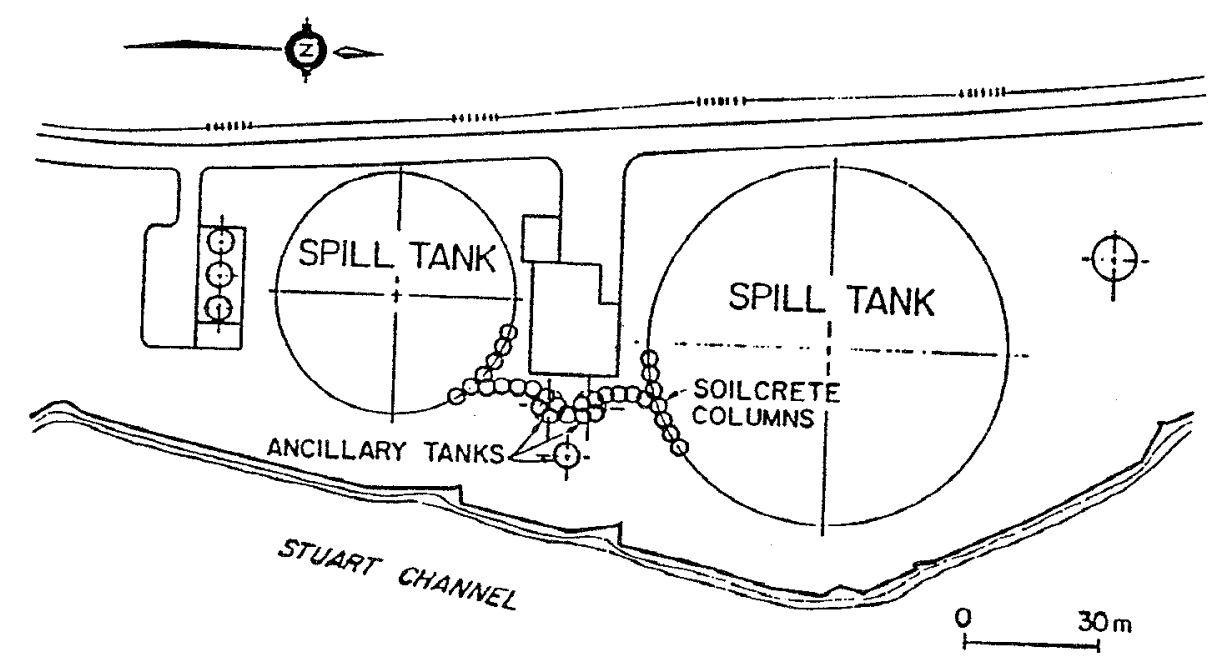

Fig. 2.29 - Site Plan of Pulp and Paper Mill Spill Tanks Showing Soil Improvement by In Situ Soil Mixing (Broomhead and Jasperse, 1992). 

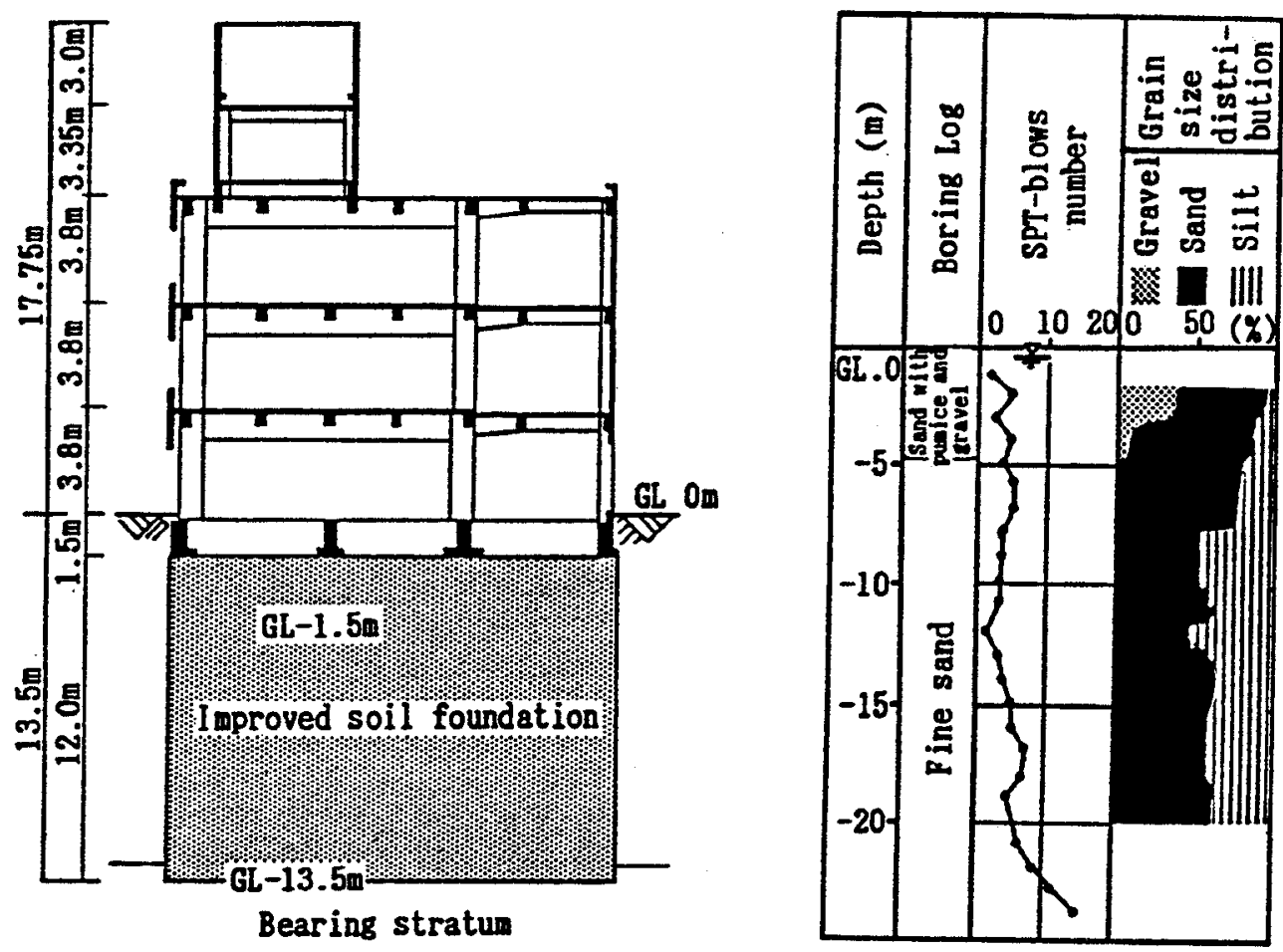

(a) Side View of Ground Improvement and Structure

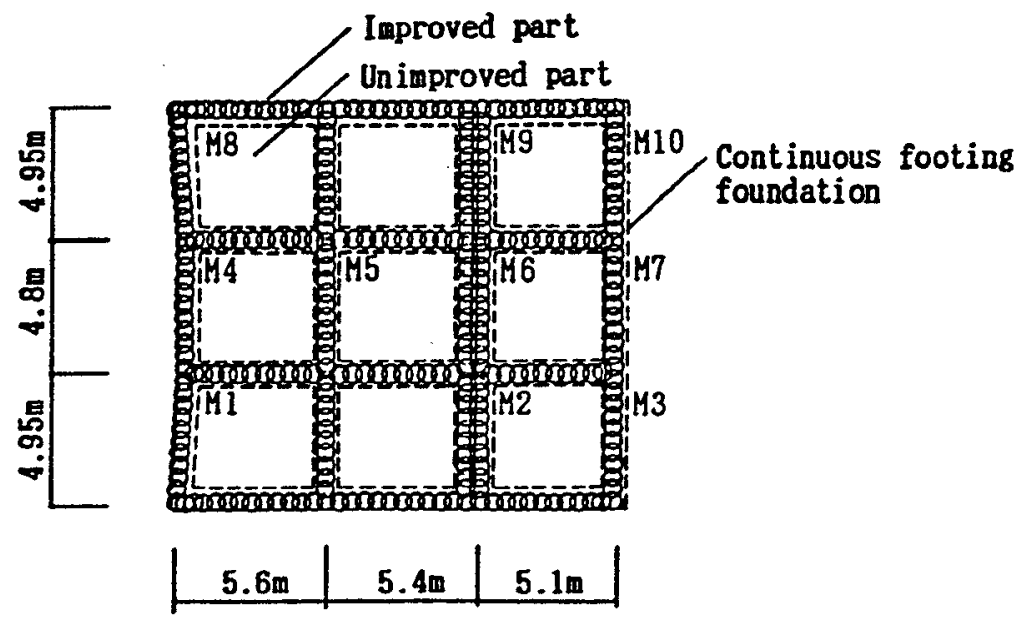

(b) Plan View of Ground Improvement.

Fig. 2.30 - Improvement of Foundation Soils for Office Building in Japan by In Situ Soil Mixing (Babasaki et al., 1991). 


\subsection{LOW VIBRATION DRAIN PILE}

\subsubsection{General}

Ono et al. (1991) described a low vibration system for constructing gravel drain piles using a large casing auger. The construction sequence of this system is illustrated in Fig. 2.31. The casing is screwed downward into the ground, while simultaneously pouring water into the casing to prevent hydrostatic imbalance and sediment flow into the casing. Gravel is discharged into the casing upon reaching the final depth. As the casing is unscrewed, gravel is pushed out the end of the casing and compacted by a rod. One study showed that standard penetration resistances measured at the midpoint between piles after installation were about 5 blow counts higher than before installation, as shown in Figs. 2.32 and 2.33. The most important factors affecting densification (Oishi and Tanaka, 1992) are: the shape of the impact surface of compaction rod, the number of compactive strokes, and the stroke length. When drains are installed without the compaction rod, little densification occurs. Systems for installing synthetic drains have also been developed (JSSFME; 1995). The low vibration drain pile technique has been used in Japan for liquefaction remediation near existing structures.

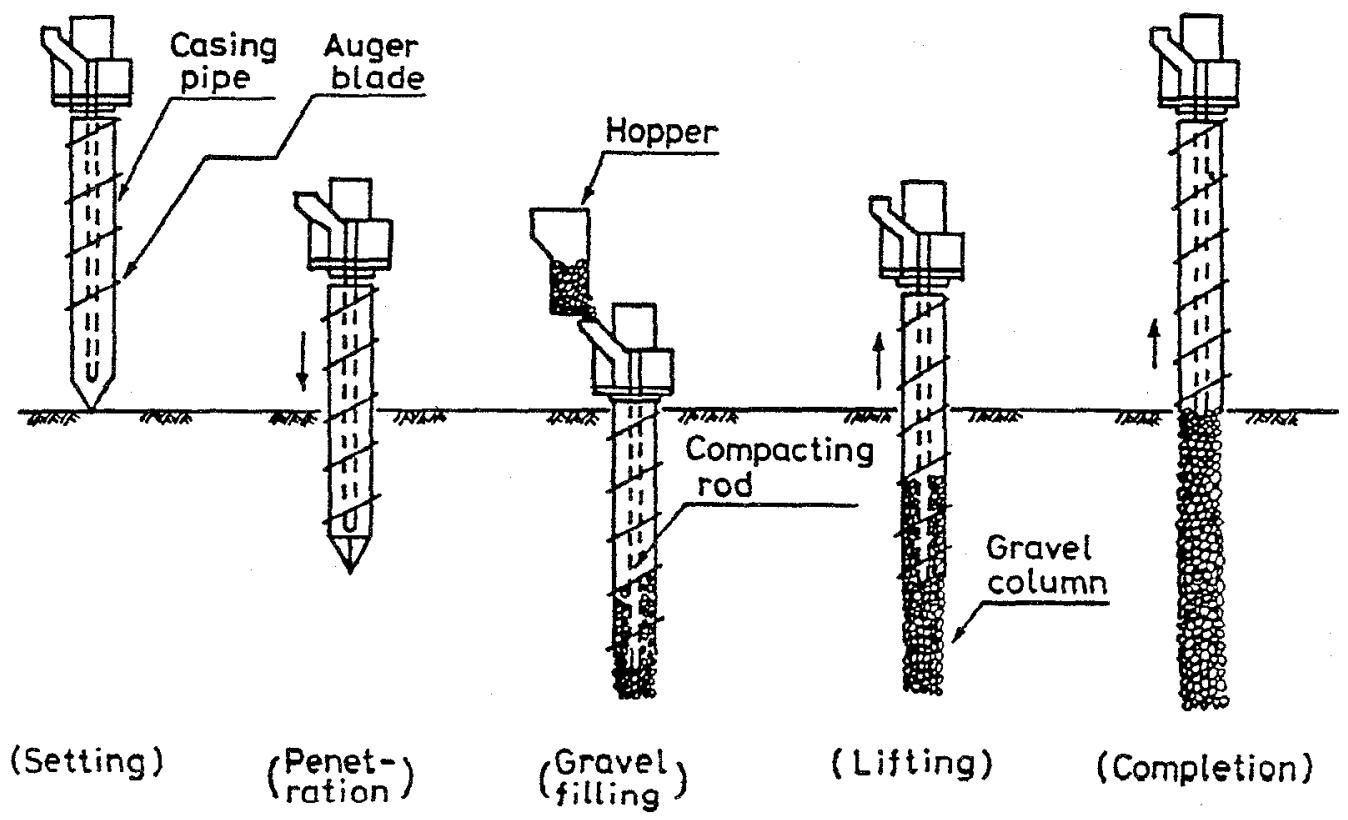

Fig. 2.31 - A Low Vibration Procedure for Installing Gravel Drain Piles (Ono et al., 1991). 

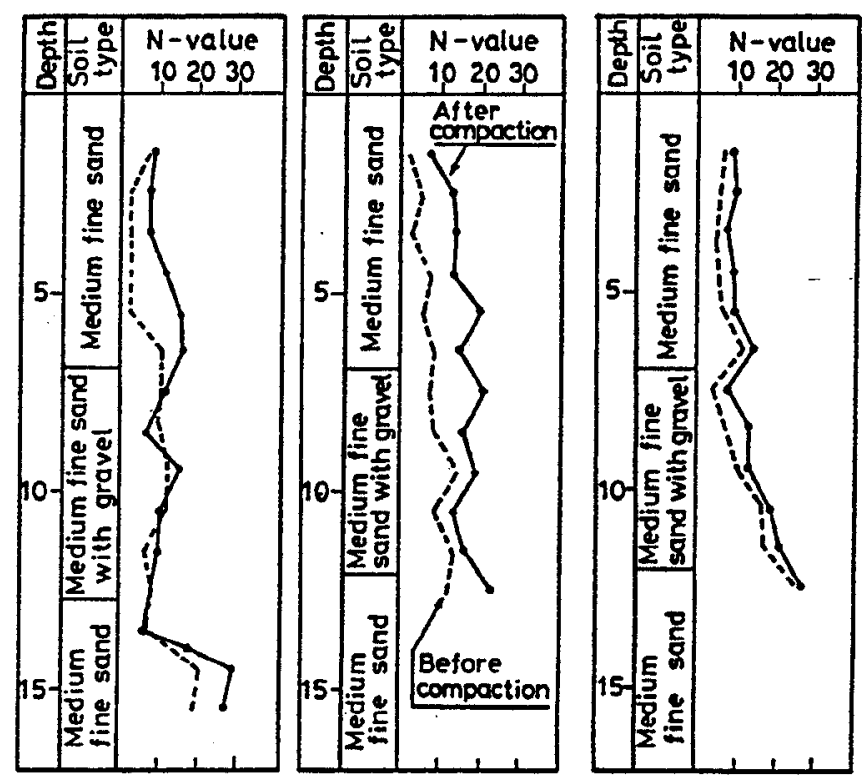

Fig. 2.32 - Change in N-value Due to Low Vibration Gravel Drain Pile Installation with Compaction Rod at Three Sites in Niigata, Japan (Ono et al., 1991).

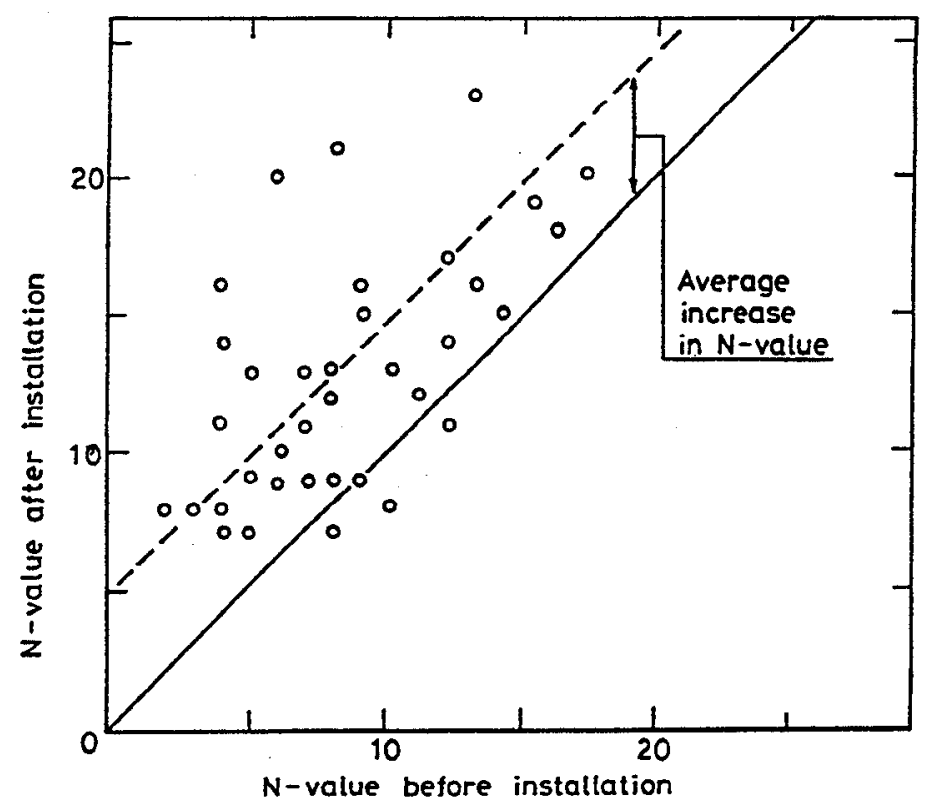

Fig. 2.33 - Increase in N-value Due to Low Vibration Gravel Drain Pile Installation with Compaction Rod at Three Sites in Niigata, Japan (Ono et al., 1991). 
There are several factors which influence the effectiveness of drain pile systems (Barksdale, 1987; Onque et al., 1987; JSSFME, 1995) including:

1. Soil Being Drained. Soil permeability is the single most useful index. Other important parameters include fines content, type of fines, coefficient of volume compressibility, grain size, gradation, and density. The drain pile technique has been applied primarily to ground with coefficient of permeability greater than $10^{-3} \mathrm{~cm} / \mathrm{s}$ and fines content under $30 \%$.

2. Ground Water Conditions. Careful consideration of seepage conditions is required. For example, construction of drains through an earth dam can increase pore pressures below the dam, and adversely affect dam safety.

3. Drain Material. Drain permeability is the single most useful index. Gravel drains are constructed of poorly graded, coarse gravel. There is no easy way to install filters around gravel drain piles, and drains may clog when liquefaction occurs. Synthetic drain materials are made of plastic enclosed by filter cloth.

4. Equipment and Installation. Installation procedures may result in drain with more fines, and smearing of interbedded cohesive soil.

5. Drain Diameter, Length, and Spacing. Excess pore water pressures will likely dissipate quicker when drain spacings are small and drain diameters are large. The diameter of gravel drains is typically 0.4 to $0.5 \mathrm{~m}$. Drain spacings of 0.8 to $1.5 \mathrm{~m}$ have been used.

Seed and Booker (1977) presented a design procedure for gravel drain pile systems assuming an infinitely pervious pipe at the center of each drain, drains having finite permeability, and radial drainage. Design charts for determining design spacings of drains extending to an impermeable layer which take well resistance into account have been proposed by Onque (1988).

The authors are not aware of any case in the United States where the low vibration drain pile technique was used for liquefaction remediation. Thus, no reliable cost information is available for this technique.

\subsubsection{Liquefaction Remediation}

The low vibration drain pile technique has been used in Japan primarily for minimizing the damaging consequences of liquefaction and ground displacement to existing structures. Four case studies are summarized in Table 2.6. All four cases involved treatment behind quay walls where low vibration levels and little earth pressure increases were required. The case study of quay walls at Kushiro Port is reviewed below. 


\subsubsection{Quay Walls at Kushiro Port, Japan}

Kushiro Port is located on the eastern shore of a northern island of Japan. As reported by Iai et al. (1994a), the port city was strongly shaken by a magnitude 7.8 earthquake in 1993 . The epicenter of the earthquake was located about $15 \mathrm{~km}$ of the coast of Kushiro. The port experienced a peak horizontal ground surface acceleration of $0.47 \mathrm{~g}$. Many quay walls were damaged when liquefaction occurred in the fill materials behind the wall. The cross section of one of the most seriously damaged walls is presented in Fig. 2.34. The steel sheet pile wall was anchored by battered steel piles. Ground conditions behind the wall are also shown in Fig. 2.34. The upper $10 \mathrm{~m}$ of soil were loose sand, characterized by very low $\mathrm{N}$-values. The loose sand was underlain by medium dense to dense sand, the original ground. The low water depth in front of the wall was about $7.5 \mathrm{~m}$. As a result of liquefaction and horizontal ground movement, cracks formed in the sheet pile wall about $4 \mathrm{~m}$ below the water level.

Quay walls with treated backfill survived the earthquake without damage. The cross section of an undamaged wall and soil treatment is shown in Fig. 2.35. The steel pipe pile wall was anchored by a steel sheet pile wall. Soil treatment behind the wall included gravel drain piles and sand compaction piles. Low vibration procedures were used to install gravel drain piles to within $5.5 \mathrm{~m}$ of the quay wall. The drain piles were $0.4 \mathrm{~m}$ in diameter and spaced 1.5 $\mathrm{m}$ on centers. The sand compaction pile technique was used to densify soils within $13 \mathrm{~m}$ of the wall. Profiles of SPT blow count before and after compaction are also shown in Fig. 2.35. The upper $11 \mathrm{~m}$ of soil exhibited $\mathrm{N}$-values of about 10 before treatment, and over 20 after treatment. The low water depth in front of the wall was about $12 \mathrm{~m}$. There was no damage to this wall. Additional studies (Iai et al., 1994b) have shown no migration of sand into the gravel drains during the earthquake. This case shows that the combination of gravel drain pile and sand compaction pile techniques was effective in preventing liquefaction and ground deformation.

\subsection{SUMMARY}

Five techniques suitable for ground improvement surrounding and adjacent to existing structures are: compaction grouting, permeation grouting, jet grouting, in situ soil mixing, and drain pile. The advantage and constraints of these five techniques are summarized in Table 2.7. Excessive disturbance to the structure is unlikely since the techniques produce low levels of work vibration. Of the five techniques, only jet grouting and in situ soil mixing can treat all liquefiable soil types. Compaction grouting may be marginally effective in treating silts. Chemical grouts cannot permeate soils with more than about $25 \%$ fines, silt and clay. It seems that drains would be ineffective in ground with low permeability. There are very few cases in which drains were applied to soil with fines content over $30 \%$ and coefficient of permeability of less than $0.001 \mathrm{~cm} / \mathrm{s}$.

Upon reviewing the available cases of liquefaction remediation, one quickly becomes aware that very little is known concerning the performance of ground improved by these techniques during strong earthquake shaking. Efforts should be given to evaluate the seismic performance of these and other cases. 
Table 2.6 - Case Studies of Liquefaction Remediation by the Low Vibration Drain Pile Technique.

\begin{tabular}{|c|c|c|c|c|}
\hline Site & $\begin{array}{c}\text { Site } \\
\text { Characteristics }\end{array}$ & $\begin{array}{l}\text { Reasons for } \\
\text { Method } \\
\text { Selection }\end{array}$ & $\begin{array}{l}\text { Construction } \\
\text { Program }\end{array}$ & Performance \\
\hline $\begin{array}{l}\text { Quay wall, } \\
\text { Kushiro Port, } \\
\text { Japan (Iai et } \\
\text { al., 1994a and } \\
\text { 1994b) }\end{array}$ & $\begin{array}{l}\text { Loose sand fill to } \\
\text { depth of about } 13 \\
\mathrm{~m} \text {. Average } \mathrm{N}- \\
\text { value before } \\
\text { treatment of } 10 .\end{array}$ & $\begin{array}{l}\text { Avoid effects of } \\
\text { vibration and earth } \\
\text { pressure increase } \\
\text { on existing steel } \\
\text { pile wall. }\end{array}$ & $\begin{array}{l}\text { Five rows of gravel drains } \\
\text { installed between wall and } \\
\text { area improved by the sand } \\
\text { compaction pile technique. } \\
\text { Drains were } 0.4 \mathrm{~m} \text { in } \\
\text { diameter and spaced } 1.5 \mathrm{~m} \text { on } \\
\text { centers. }\end{array}$ & $\begin{array}{l}\text { No damage to walls } \\
\text { with treated backfill } \\
\text { during the } 1993 \\
\text { Kushiro-Oki } \\
\text { earthquake; a max }= \\
0.47 \mathrm{~g} \text {. Walls with } \\
\text { untreated backfill } \\
\text { suffered moderate } \\
\text { damage. }\end{array}$ \\
\hline $\begin{array}{l}\text { Quay wall, } \\
\text { Chiba Port, } \\
\text { Japan } \\
\text { (JSSFME, } \\
\text { 1995). }\end{array}$ & $\begin{array}{l}\text { Liquefiable fill } \\
\text { material to depth } \\
\text { of about } 20 \mathrm{~m} \text {. }\end{array}$ & $\begin{array}{l}\text { Avoid effects of } \\
\text { vibration and earth } \\
\text { pressure increase } \\
\text { on existing steel } \\
\text { sheet pile wall. }\end{array}$ & $\begin{array}{l}\text { On the land side of the wall, } \\
\text { fill treated by vibro- } \\
\text { compaction to within } 20 \mathrm{~m} \text { of } \\
\text { wall. Gravel drains installed } \\
\text { between wall and compacted } \\
\text { area. On the sea side of the } \\
\text { wall, fill treated by the sand } \\
\text { compaction pile technique. }\end{array}$ & No data given. \\
\hline $\begin{array}{l}\text { Quay wall, } \\
\text { Akita Port, } \\
\text { Japan } \\
\text { (JSSFME, } \\
\text { 1995). }\end{array}$ & $\begin{array}{l}\text { Liquefiable fill } \\
\text { material to depth } \\
\text { of about } 10 \mathrm{~m} \text {. }\end{array}$ & $\begin{array}{l}\text { Avoid effects of } \\
\text { vibration and earth } \\
\text { pressure increase } \\
\text { on new steel sheet } \\
\text { pile wall. }\end{array}$ & $\begin{array}{l}\text { One row of gravel drains } \\
\text { installed between new wall } \\
\text { and area improved by vibro- } \\
\text { compaction. Drains were } 0.5 \\
m \text { in diameter. }\end{array}$ & No data given. \\
\hline $\begin{array}{l}\text { Quay wall, } \\
\text { Ariake Island, } \\
\text { Tokyo Bay, } \\
\text { Japan } \\
\text { (Yashinsky, } \\
\text { 1994). }\end{array}$ & Loose sand fill. & $\begin{array}{l}\text { Avoid effects of } \\
\text { vibration and earth } \\
\text { pressure increase } \\
\text { on timber pile and } \\
\text { steel sheet pile } \\
\text { wall. }\end{array}$ & $\begin{array}{l}\text { Nearly } 4000 \text { gravel drains } \\
\text { installed in an area of } 2770 \\
\mathrm{~m}^{2} . \text { Drains were } 0.5 \mathrm{~m} \text { in } \\
\text { diameter and } 17 \mathrm{~m} \text { long, and } \\
\text { spaced } 0.8 \mathrm{~m} \text { apart. }\end{array}$ & No data given. \\
\hline
\end{tabular}




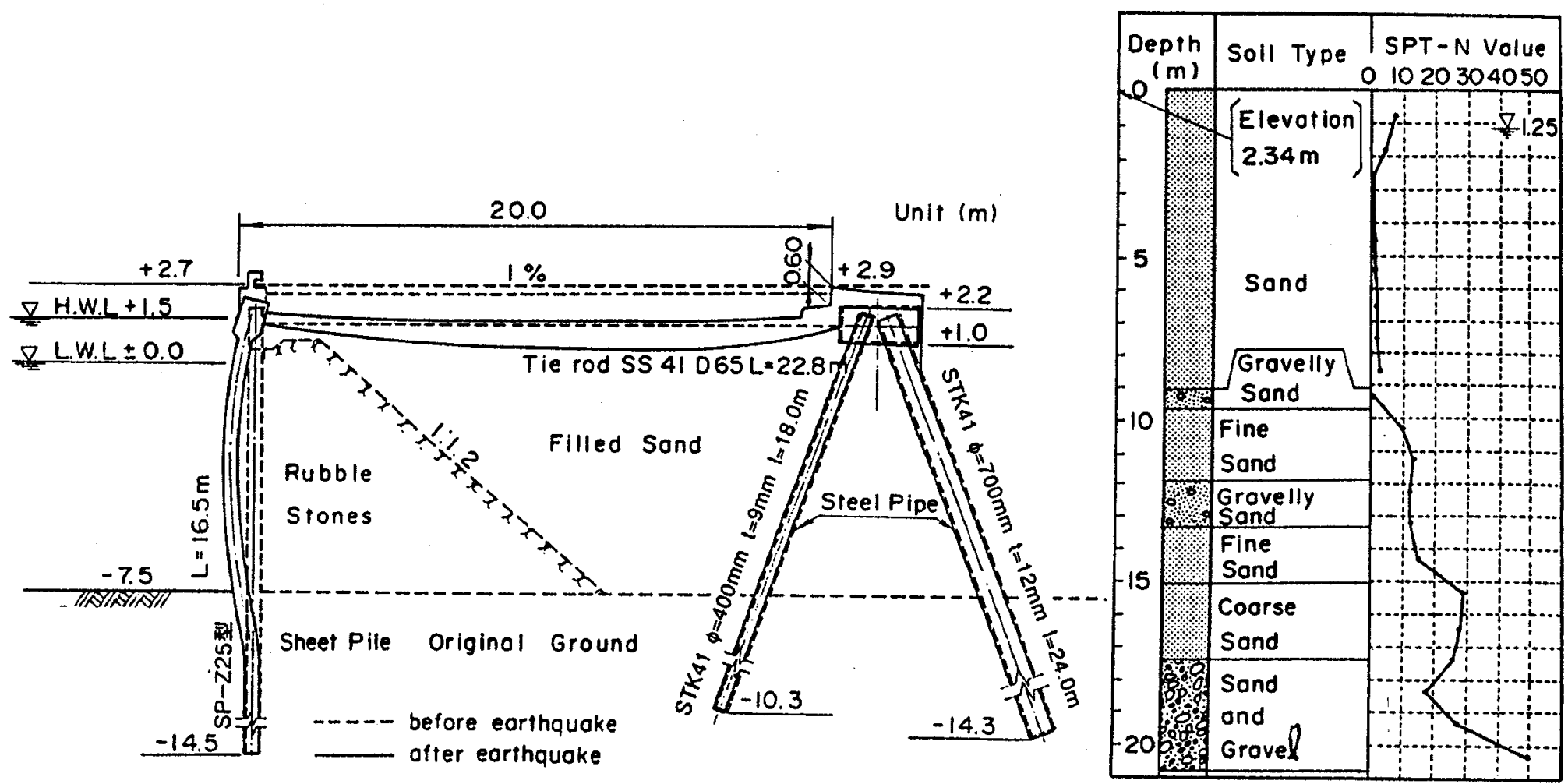

Fig. 2.34 - Cross Section of a Damaged Steel Sheet Pile Quay Wall at Kushiro Port, Japan, Showing Ground Conditions and Wall Deformations Caused by Liquefaction-induced Horizontal Ground Movement (Iai et al., 1994). 


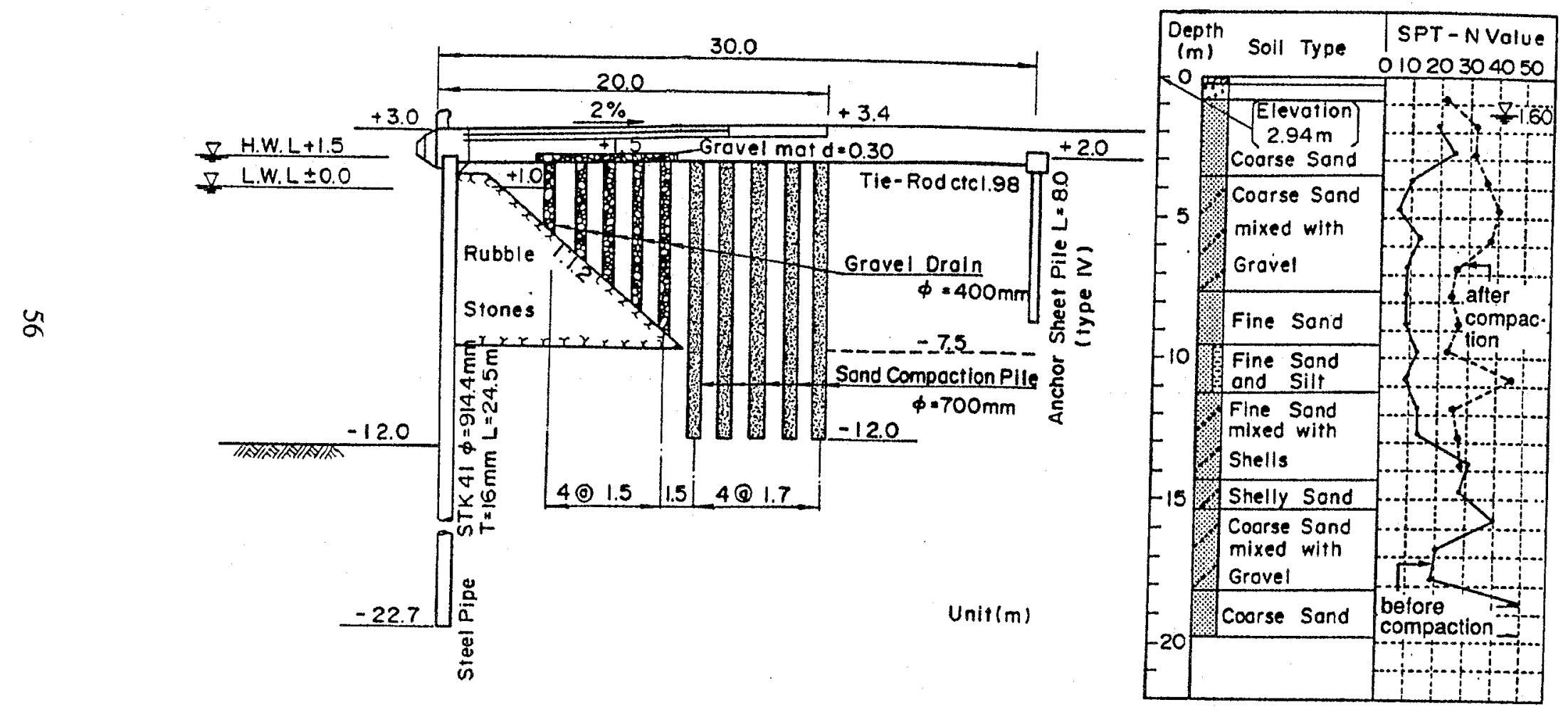

Fig. 2.35 - Cross Section of an Undamaged Steel Pipe Pile Quay Wall at Kushiro Port, Japan, Showing Ground Conditions and Soil Improvement by Gravel Drain Pile and Sand Compaction Pile (Iai et al., 1994). 
Table 2.7 - Advantages and Constraints for Five Ground Improvement Techniques.

\begin{tabular}{|c|c|c|c|c|c|}
\hline Advantage or Constraint & $\begin{array}{l}\text { Compaction } \\
\text { Grouting }\end{array}$ & $\begin{array}{l}\text { Permeation } \\
\text { Grouting }\end{array}$ & $\begin{array}{c}\text { Jet } \\
\text { Grouting }\end{array}$ & $\begin{array}{l}\text { In Situ Soil } \\
\text { Mixing }\end{array}$ & Drain Pile \\
\hline $\begin{array}{l}\text { Produces low levels of } \\
\text { work vibration and noise }\end{array}$ & yes & yes & yes & yes & yes \\
\hline Soil types not treatable & $\begin{array}{l}\text { saturated } \\
\text { clayey soils }\end{array}$ & $\begin{array}{c}\text { soils with } \\
\text { fines content } \\
\text { of over } \\
\text { about } 25 \%\end{array}$ & $\begin{array}{l}\text { irregular } \\
\text { geometries } \\
\text { in cobbly } \\
\text { soils and } \\
\text { open gravel }\end{array}$ & $\begin{array}{l}\text { boulders, } \\
\text { logs, and } \\
\text { hard strata } \\
\text { can be a } \\
\text { problem }\end{array}$ & $\begin{array}{l}\text { soils with } \\
\text { significant } \\
\text { fines content } \\
\text { and very low } \\
\text { permeability }\end{array}$ \\
\hline $\begin{array}{l}\text { Treatment beneath existing } \\
\text { structures possible }\end{array}$ & yes & yes & yes & $\begin{array}{l}\text { earth } \\
\text { structures }\end{array}$ & $\begin{array}{l}\text { earth } \\
\text { structures }\end{array}$ \\
\hline Small diameter drilling & yes & yes & yes & no & no \\
\hline $\begin{array}{l}\text { Low headroom work } \\
\text { possible }\end{array}$ & yes & yes & yes & no & $\begin{array}{l}\text { plastic drain } \\
\text { pile }\end{array}$ \\
\hline Selective treatment possible & yes & yes & yes & no & no \\
\hline $\begin{array}{l}\text { Intimate contact with } \\
\text { structure possible }\end{array}$ & limited & yes & yes & no & no \\
\hline $\begin{array}{l}\text { Treatment at very low } \\
\text { confinement possible }\end{array}$ & marginal & yes & yes & yes & yes \\
\hline $\begin{array}{l}\text { Without care, likely } \\
\text { disturbance }\end{array}$ & $\begin{array}{l}\text { significant } \\
\text { ground } \\
\text { movement; } \\
\text { damaged } \\
\text { pipes }\end{array}$ & $\begin{array}{l}\text { significant } \\
\text { ground } \\
\text { movement; } \\
\text { damaged } \\
\text { pipes }\end{array}$ & $\begin{array}{l}\text { significant } \\
\text { ground } \\
\text { movement; } \\
\text { damaged } \\
\text { pipes }\end{array}$ & $\begin{array}{l}\text { significant } \\
\text { ground } \\
\text { movement; } \\
\text { damaged } \\
\text { pipes }\end{array}$ & $\begin{array}{l}\text { damaged } \\
\text { pipes }\end{array}$ \\
\hline Quantity of waste produced & little & little & large & some & little \\
\hline $\begin{array}{l}\text { Prevents seismic-induced } \\
\text { subsidence }\end{array}$ & yes & yes & $\begin{array}{l}\text { depends on } \\
\text { design }\end{array}$ & $\begin{array}{l}\text { depends on } \\
\text { design }\end{array}$ & no \\
\hline $\begin{array}{l}\text { Well-defined specifications } \\
\text { required }\end{array}$ & yes & yes & yes & yes & yes \\
\hline $\begin{array}{l}\text { Engineered/observational } \\
\text { approach required }\end{array}$ & yes & yes & yes & yes & yes \\
\hline $\begin{array}{l}\text { Quality control during } \\
\text { installation required }\end{array}$ & yes & yes & yes & yes & yes \\
\hline Other evaluations required & $\begin{array}{l}\text { site pilot } \\
\text { study }\end{array}$ & $\begin{array}{l}\text { site pilot } \\
\text { study; } \\
\text { durability; } \\
\text { creep; health } \\
\text { and safety }\end{array}$ & $\begin{array}{l}\text { site pilot } \\
\text { study; } \\
\text { durability }\end{array}$ & $\begin{array}{l}\text { site pilot } \\
\text { study; } \\
\text { durability }\end{array}$ & $\begin{array}{l}\text { site pilot } \\
\text { study; } \\
\text { seepage; } \\
\text { clogging }\end{array}$ \\
\hline Can be highly cost-effective & yes & yes & yes & yes & yes \\
\hline Cost & expensive & expensive & expensive & expensive & expensive \\
\hline
\end{tabular}




\section{CHAPTER 3}

\section{GROUND IMPROVEMENT NEAR EXISTING LIFELINES}

\subsection{INTRODUCTION}

Ground improvement near existing lifelines requires special considerations (Glaser and Chung, 1995) because of the following:

- Work vibrations may damage lifeline, which could have very serious consequences;

- Soil needing improvement is obstructed by the lifeline;

- Scope of work is of large areal extent, yet may be limited to a narrow right-of-way;

- Subsurface conditions will vary greatly along alignment;

- Extent of treatment required to protect lifeline is not known;

- Exact location and condition of buried utilities might not be known; and

- Improvement might adversely affect regional hydrology.

\subsection{PIPELINES AND CONDUITS}

\subsubsection{General}

Great care must be exercised in the planning and execution of ground improvement near existing pipelines and conduits. The following recommendations by Gould et al. (1992) for excavation work near utilities and buildings directly apply:

Before construction the designer and contractor should investigate available utility records and prepare composite drawings showing all information obtained from these records. The utilities should be identified on site to the extent of painting their position on the pavement before construction. Test pits should be dug to verify that critical utilities are in the location indicated. Similar procedures should be followed for affected buildings. All existing records of overhead, below grade and adjacent structures should be investigated to determine the location and nature of foundations and the sensitivity of these structures to ground movement. 
An existing condition survey and an optical survey of all utilities and buildings should be performed prior to construction. The contractor relocating utilities during construction should maintain an accurate record of the relocated position. Background levels of noise and vibration should also be determined before the start of work. The monitoring program should continue for a sufficient period after construction to assure that the utilities and structures have stabilized and that no further movements are occurring. At that time a final condition survey is performed to establish that damages have not occurred to the structures and to protect against damage claims.

In addition, shut off valves should be identified. For some utilities, such as gas lines, it is advisable to temporarily shut down the section where ground improvement will be performed.

The sensitivity of pipelines to ground vibration and deformation depends on a number of factors (Ford and Bratton, 1991; O'Rourke and Palmer, 1994) including joint type, material type, age, diameter, thickness, internal pressure, and configuration. Pipe failures and leaks are most likely to occur at pipe joints and connections. Joint types most vulnerable include threaded, caulked, and oxy-acetylene welded. Some pipe materials, such as cast iron, are rigid and can break if significant ground displacement occurs. Other pipe materials, such as ductile iron and steel, are more flexible and less susceptible to structural breakage. Pipes of great age are typically highly sensitive. Pipes located below the ground surface, illustrated in Figs. 3.1a and $3.1 \mathrm{~b}$, are more likely to develop compressive and tensile forces in response to ground deformation than pipes located above the ground surface or mounted in conduits, illustrated in Figs $3.1 \mathrm{c}, 3.1 \mathrm{~d}, 3.1 \mathrm{e}, 3.1 \mathrm{f}$ and $3.1 \mathrm{~g}$. Site pilot studies are highly recommended to verify that the method selected for ground improvement will not damage the pipeline.

\subsubsection{Case Studies of Ground Improvement Near Pipelines and Conduits}

Reported case studies of ground improvement near pipelines and conduits are not common. The two reported cases that the authors are aware of are reviewed below.

\subsubsection{Containment Wall at Utility Crossings, Michigan}

As reported by Gazaway and Jasperse (1992), jet grouting was used to construct sections of a vertical containment wall, up to $7.3 \mathrm{~m}$ deep, where underground pipes and other utilities crossed the barrier. A typical section is shown in Fig. 3.2. In areas unobstructed by underground utilities, the barrier had been constructed by the slurry trench technique. Jet grouting was used to join the wall since utilities could not be removed or disturbed. Based on the results of a pilot study conducted at the site, the center-to-center spacing of the jet grouted columns was conservatively specified at $0.6 \mathrm{~m}$ for most of the work. Grout pressures were set at about $40 \mathrm{MPa}$. Drill rod rotation and withdrawal rates were set at about 1.3 r.p.m. and 0.4 $\mathrm{m} / \mathrm{min}$, respectively. To ensure closure beneath the larger diameter (up to $1.2 \mathrm{~m}$ ) pipes, much slower rotation and withdrawal rates were used. Near the smaller and more fragile conduits, 
column spacings were tightened, and rotation and withdrawal rates were increased. Jet pressures of about $35 \mathrm{MPa}$ were used for a few short periods in the immediate vicinity of particularly sensitive conduits. Approximately 530 square meters of containment barrier was installed by jet grouting. The jetting action caused no detectable damage to any of the underground utilities.

\subsubsection{Settled Pipes at Waste Water Treatment Plant}

A concrete effluent channel and three buried concrete pipelines connected to the channel at a waste water treatment plant had settled as much as $190 \mathrm{~mm}$ within two years after their construction (Scherer and Weiner, 1993). Joints in the pipelines had opened as a result of the settlement. The diameters of the three pipes were $1.22,1.52$ and $2.13 \mathrm{~m}$. It was concluded that settlement was caused by consolidation of a thick lens of very soft organic silt and clay beneath the channel. To avoid costly excavation, dewatering, and problems posed by other utilities within the area, the concrete effluent channel was raised and supported with hydraulically driven steel mini piles located on the interior of the channel. The buried pipes were raised and supported with compaction grout piles.

As described by Scherer and Weiner (1993), compaction grout piles were installed on each side of the concrete pipe at joint locations or intervals not exceeding $3 \mathrm{~m}$. The grout piles were designed to have a diameter of about $0.6 \mathrm{~m}$ and extend from the shale bedrock at elevation $-15.2 \mathrm{~m}$ to the bottom of the concrete pipe at elevation $+2.7 \mathrm{~m}$, as illustrated in Fig. 3.3. The cutoff criteria for grout injection was set at a maximum pump pressure of $4 \mathrm{MPa}$, or when unwanted pipe lift or ground heave occurred. Grout injection volumes for the initial piles were only $0.023 \mathrm{~m}^{3}$ per linear meter within a dense sand layer overlying bedrock. Thus, the tips of subsequent grout piles were located in the dense sand, about elevation $+12.2 \mathrm{~m}$. Following the construction of the vertical grout piles, grout was injected beneath the center of the concrete pipe to lift the pipe, as depicted in Fig. 3.3. Finally, the interface between the vertical grout columns and concrete pipe was filled with additional grout to establish positive support. A total of fifty-two vertical and angle grout columns were installed.

\subsubsection{Liquefaction Remediation}

Conceptual diagrams showing various types of ground improvement near a buried pipeline are presented in Fig. 3.4. These diagrams suggest that the pipeline could be protected from subsidence and uplift using permeation or jet grouting. Horizontal ground movement could be prevented by any one of the five low vibration ground improvement techniques depending on the constrains summarized in Table 2.7. Compaction, permeation and jet grouting are capable of improving soil conditions beneath the pipeline. However, compaction grouting, Fig. 3.4c, may not sufficiently compact soils immediately adjacent to the pipeline. The in situ soil mixing and drain pile techniques could be effectively employed a short distance away, as depicted in Figs. 3.4c and 3.4d. The safe application distance depends on the condition of the pipeline, and the level of disturbance generated by the technique. 
The extent of treatment is determined from seismic stability analyses, and depends on a number of factors including soil properties, stratigraphy, ground slope, pipeline-ground failure crossing angle, depth of pipe burial, piping configuration, and anchoring. Permeation grouting, jet grouting, or in situ soil mixing are alternatives for work limited to a narrow right-of-way. Jet grouting and in situ soil mixing may be the most effective techniques for soils with a high silt content. The ground water hydrology would be least affected by compaction grouting and drain pile, since no continuous barrier is formed. However, drain piles may create serious problems if applied in dams and areas of artesian pressure. 


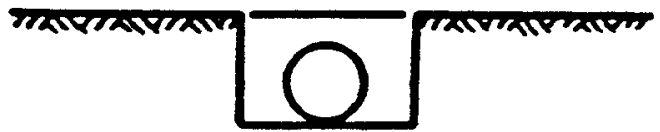

(a)
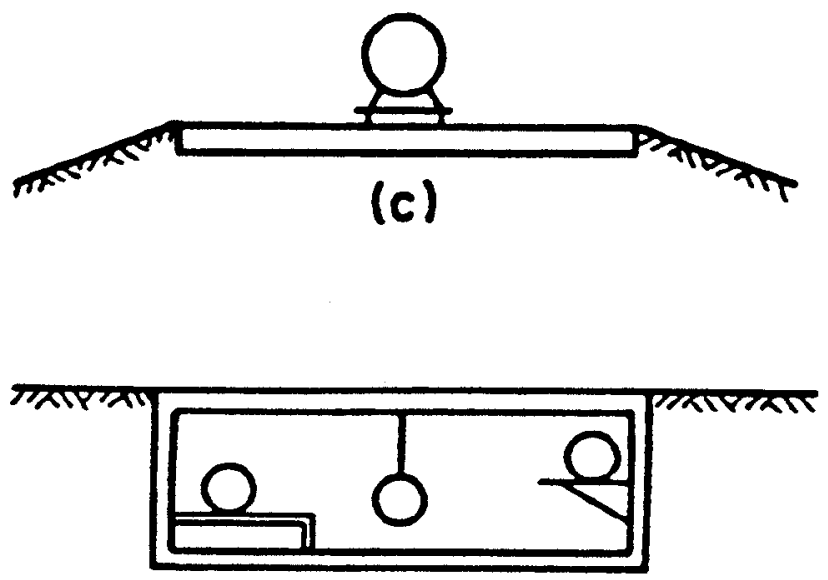

(e)

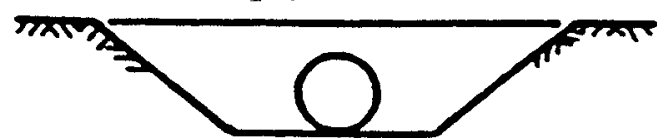

(b)

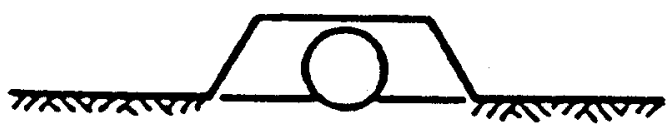

(d)

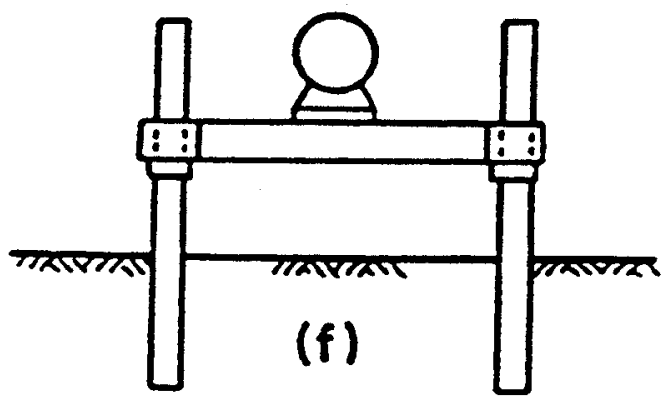

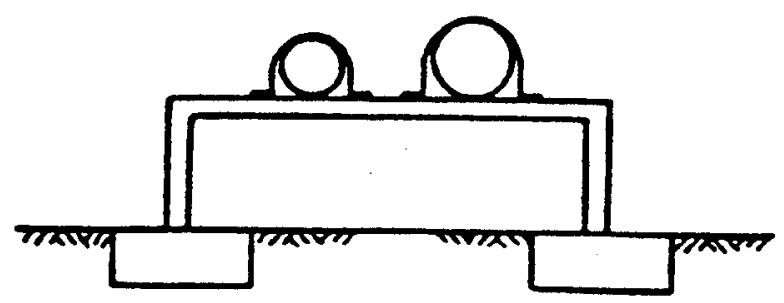

(g)

Fig. 3.1 - Piping Configurations (Hall and O'Rourke, 1991). 


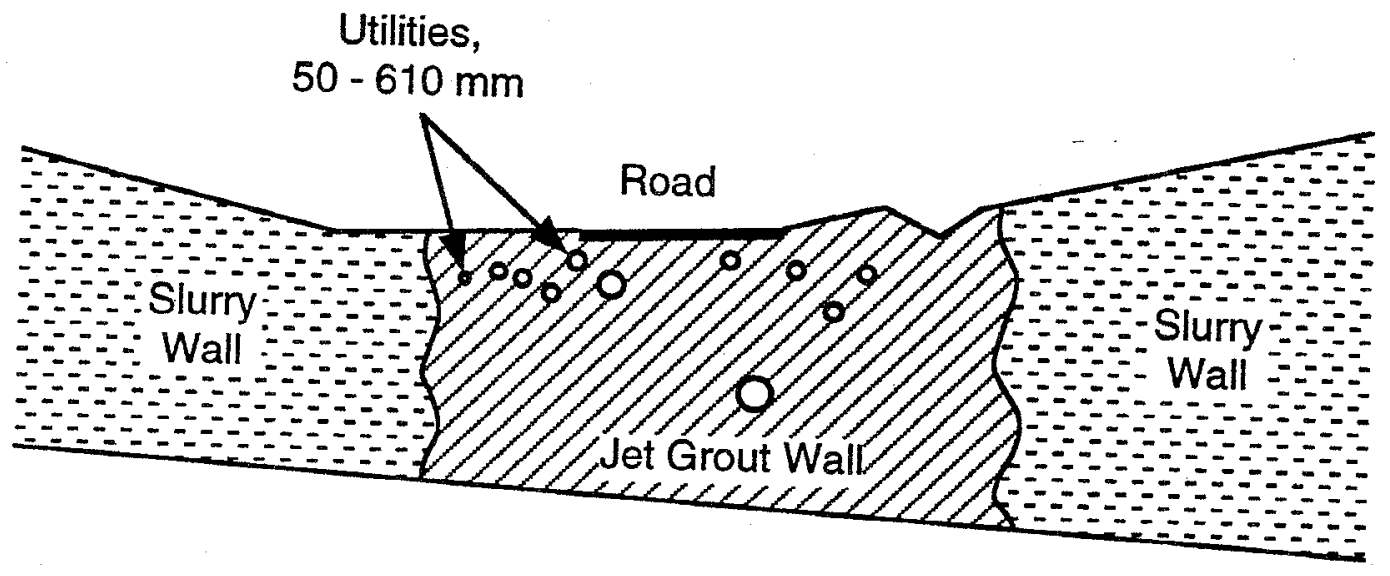

Fig. 3.2 - Construction of Cutoff Wall at Utility Crossing by Jet Grouting (after Gazaway and Jasperse, 1992).

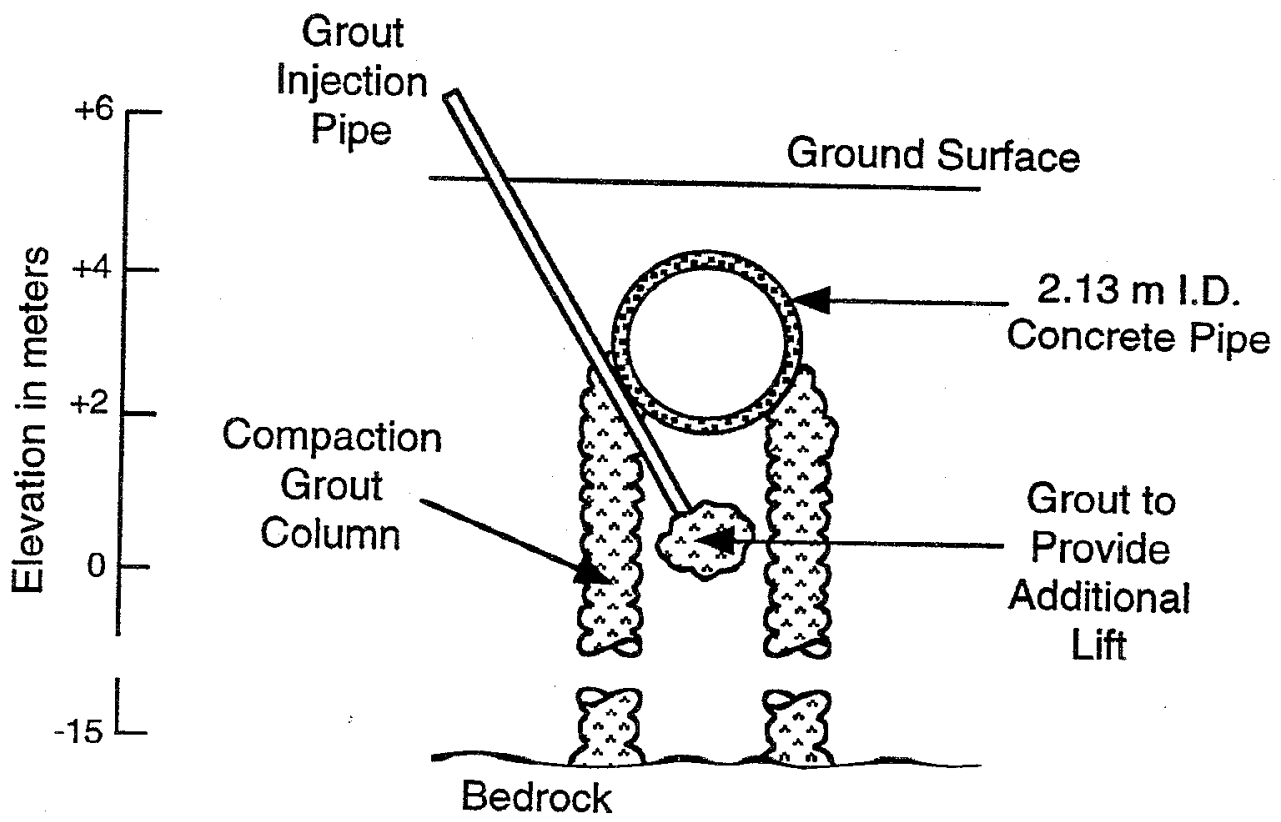

Fig. 3.3 - Underpinning and Leveling Settled Pipe by Compaction Grouting (after Scherer and Weiner, 1993). 


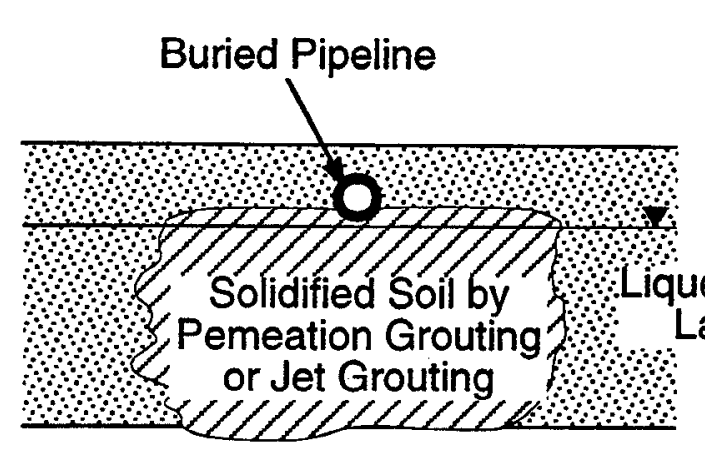

(a)

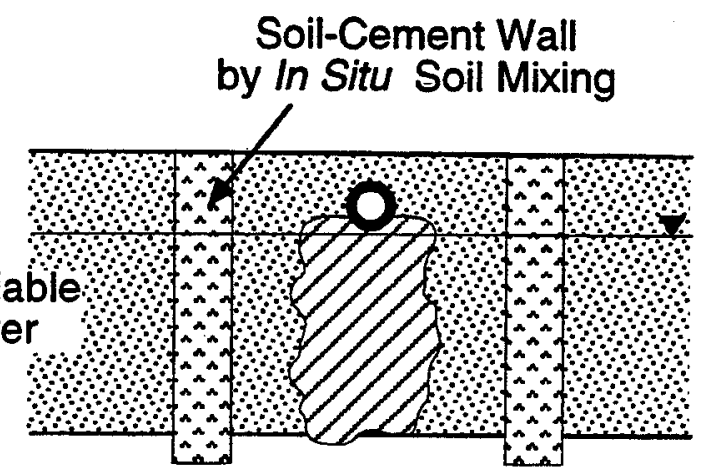

(b)

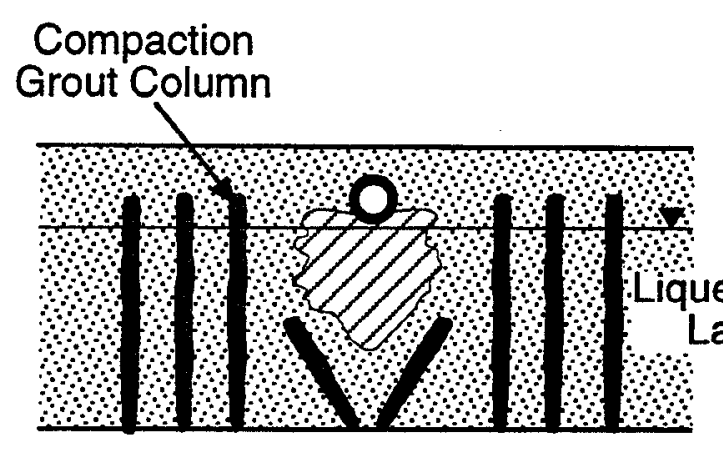

(c)

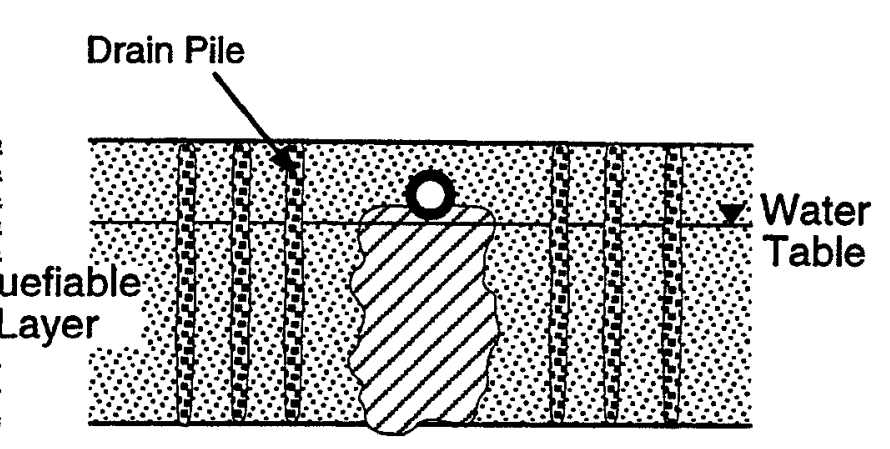

(d)

Fig. 3.4 - Liquefaction Remediation Near Buried Pipeline By Combination of Ground Improvement Techniques. 


\subsection{TRANSPORTATION LINES}

\subsubsection{General}

Great care is required in the planning and execution of ground improvement near existing transportation lines, such as roadways and rail lines. Sometimes the flow of traffic can be temporarily stop or divert. However, it may be required that the-work not cause serious damage to the roadway or rail line so that traffic flow can resume. Site pilot studies should be conducted to verify that ground improvement will not cause damage.

\subsubsection{Case Studies of Ground Improvement Near Transportation Lines}

Reported case studies of ground improvement near transportation lines are not common. Four cases involving a highway viaduct, two rail lines, and an airport runway are reviewed in following paragraphs.

\subsubsection{Highway Viaduct, San Diego}

From the report by Jackura and Abghari (1994), the I-805 viaduct crossing the San Diego River, California, is about $36 \mathrm{~m}$ high and $1500 \mathrm{~m}$ long. It is a cast-in-place, prestressed box girder design constructed in 1972. A simplified cross section showing the viaduct and foundation soils is presented in Fig. 3.5. The soil profile consists of 0 to $6 \mathrm{~m}$ of well compacted fill, underlain by $18 \mathrm{~m}$ of natural sand and gravel with interbedded layers of silt. Corrected SPT blow counts, $\left(\mathrm{N}_{1}\right)_{60}$, in the upper $8 \mathrm{~m}$ of natural sand and gravel range from 6 to 59. It was determined that liquefaction would occur in the upper $5 \mathrm{~m}$ of natural sand and gravel by a peak ground surface acceleration as low as $0.2 \mathrm{~g}$. Estimates of possible horizontal ground displacement ranged from 1.4 to $4.5 \mathrm{~m}$, well above the maximum tolerable value of $0.8 \mathrm{~m}$.

An underground buttress composed of stone columns was considered the most economical alternative, and permanent dewatering the next best alternative. The buttress was constructed between Bents 9 and 10 at the toe of the steepest ground slope, as depicted in Fig. 3.5. The width of the buttress, $15 \mathrm{~m}$, was determined from seismic slope stability analyses assuming an internal friction angle of $39^{\circ}$ for the stone columns, and a minimum residual strength of $1.44 \mathrm{kPa}$ for the liquefiable soil. Right-of-way restrictions limited the length of the buttress to roughly $85 \mathrm{~m}$.

While stone column (vibro-replacement) in not one of the five low vibration techniques, this case illustrates the application of other techniques when soil needing improvement is not obstructed by the lifeline and when work vibration will not cause damage. One approach to reducing near-surface vibration has been to pre-auger to the problem soil, and then lower the vibratory probe down the augered hole before applying the vibro-replacement technique. According to Baez (1995), the pre-auger approach has permitted ground improvement by vibro-replacement to within $3 \mathrm{~m}$ of many near-surface lifelines. 


\subsubsection{Settled Railroad Embankment, Georgia}

A section of rail line in northern Georgia passed through a sinkhole prone area (Brill and Hussin, 1992). The rail line had been repaired a number of times by dumping ballast into the depressions to maintain the grade. However, sinkholes continued to develop at an increased rate. Rail traffic had to be slowed from $100 \mathrm{~km}$ per hour to less than $20 \mathrm{~km}$ per hour, and a watchman was assigned to patrol a 600 -m-long section of track 24 hours a day.

As reported by Brill and Hussin (1992), compaction grouting was used to remediate conditions beneath the rail line. Grout holes were drilled at an angle from the eastern edge of the embankment $1.5 \mathrm{~m}$ into bedrock, as depicted in Fig. 3.6. The holes traversed the dip of the limestone bedrock, thereby enhancing the compaction process. Primary grout holes were spaced on $6 \mathrm{~m}$ centers, with injection volumes set at $7.5 \mathrm{~m}^{3}$ per linear meter of casing for the first $0.9 \mathrm{~m}$ above rock, and $5 \mathrm{~m}^{3}$ per linear meter in the soft/loose soil. These volumes were generally achieved. Secondary grout holes split the primary holes, with injection volumes set at $7.5 \mathrm{~m}^{3}$ per linear meter for first $0.3 \mathrm{~m}$ above bedrock, $2.5 \mathrm{~m}^{3}$ per linear meter for next $0.6 \mathrm{~m}$, and $1.2 \mathrm{~m}^{3}$ per linear meter in soft/loose soil. However, ground heave at the surface was typically observed before these target volumes were reached. When secondary injections seemed insufficient, tertiary grouting was performed between the secondary holes. A total of $1326 \mathrm{~m}^{3}$ of grout was injected into 88 holes. Since the completion of the grouting program, settlement of the ground beneath the tracks has stopped and trains have been able to resume their regular speeds without a watchman.

\subsubsection{Tunnel Construction Beneath Rail Line, Switzerland}

A new underpass was to be constructed beneath a busy rail line that separates the town of Fluelen from Lake Uri (Steiner et al., 1992). The upper $3 \mathrm{~m}$ of soil below the railroad embankment consisted of gravel and cobble fill. The fill was underlain by wood and stone rubble, remnants of a former boat landing facility. Below the rubble, fluvial and lacustrine deposits were interfingered ranging from silt to gravel. These natural soils were characterized by SPT blow counts between 1 and 10 . The ground water table was located close to the surface and was in direct contact with the lake. Two cut-off walls were needed to make dewatering effective and prevent excessive settlement beneath the tracks.

As reported by Steiner et al. (1992), jet grouting was used to construct the two cut-off walls. It was determined from a pilot study that columns with diameters of $1.5 \mathrm{~m}$ and $1.2 \mathrm{~m}$ could be constructed with the double jet system and single jet system, respectively. The double jet system, i.e. grout jet shrouded with air, was used to constructed columns with dip greater than $20^{\circ}$. The single jet system, which uses no air, was used for the flatter columns. Each wall consisted of three rows of columns. The general arrangement columns for one row is shown in Fig. 3.7. The outer row was constructed first, and the central row was constructed last with the axes of columns shifted so that they were positioned between the outer and inner columns. Cores taken from two borings drilled through the final wall revealed no evidence of joints between columns. Core specimens after 28 days exhibited an unconfined compressive strength 
between 6 and $10 \mathrm{MPa}$. During the two months of jet grouting work, the tracks underwent 4 $\mathrm{mm}$ of settlement, about the same rate observed before the work started. Measured settlement during excavation of the underpass was about $3 \mathrm{~mm}$.

\subsubsection{Tunnel Construction Beneath Airport Runway, Japan}

A 70-m-wide underpass for vehicles was planned beneath a functioning airport runway in Japan (Ichihashi et al., 1992). The runway had been built on top of a concrete slab supported by steel sheet piles, as depicted in Fig. 3.8. However, not all sheet piles extended to the bearing layer and some underpinning was necessary to support the excavation. The excavation would require dewatering, which could also cause settlement. It was determined that settlement and heave to the runway could not exceed $50 \mathrm{~mm}$.

As reported by Ichihashi et al. (1992), jet grouting was used to form soil-cement piles that extend to the bearing layer, and cut-off walls to prevent lowering of the water level outside the excavation. Since the soil could be improved by jet grouting through drill holes less than $220 \mathrm{~mm}$ in diameter, minimal damage occurred to the runway. To prevent settlement, a steel guide casing was first installed down to the top of the zone to be grouted, as illustrated in Fig. 3.9. The grout pipe was then lowered down through the guide casing and advanced to the final depth, $2 \mathrm{~m}$ into the bearing layer. A tank containing a sand pump was attached to the casing guide at the ground surface to prevent waste slurry from flowing onto the runway. A triple jet system was used. Grout injection pressures varied between 30 and $40 \mathrm{MPa}$. Air injection pressures varied between 0.6 and $0.7 \mathrm{MPa}$. The drill rod was withdrawn at a rate between 50 and $100 \mathrm{~mm} / \mathrm{min}$. During the excavation of the tunnel, measured settlement and heave of the runway surface was less than $3 \mathrm{~mm}$.

\subsection{SUMMARY}

Upon reviewing the available cases of ground improvement near existing lifelines, one quickly becomes aware that very little has been gathered on the subject. Nevertheless, limited case studies showed that with great care and depending on their nature and condition permeation and jet grouting could improve soil conditions immediately adjacent to lifelines. Compaction grouting could be applied beneath lifelines, but may not sufficiently compact soils immediately adjacent to them. The in situ soil mixing and drain pile techniques could be effectively employed a short distance away from lifelines. Beyond a certain distance, other less expensive ground improvement techniques, such as vibro-compaction and vibro-replacement, could be used. A combination of techniques may provide the most cost-effective ground improvement solution. 


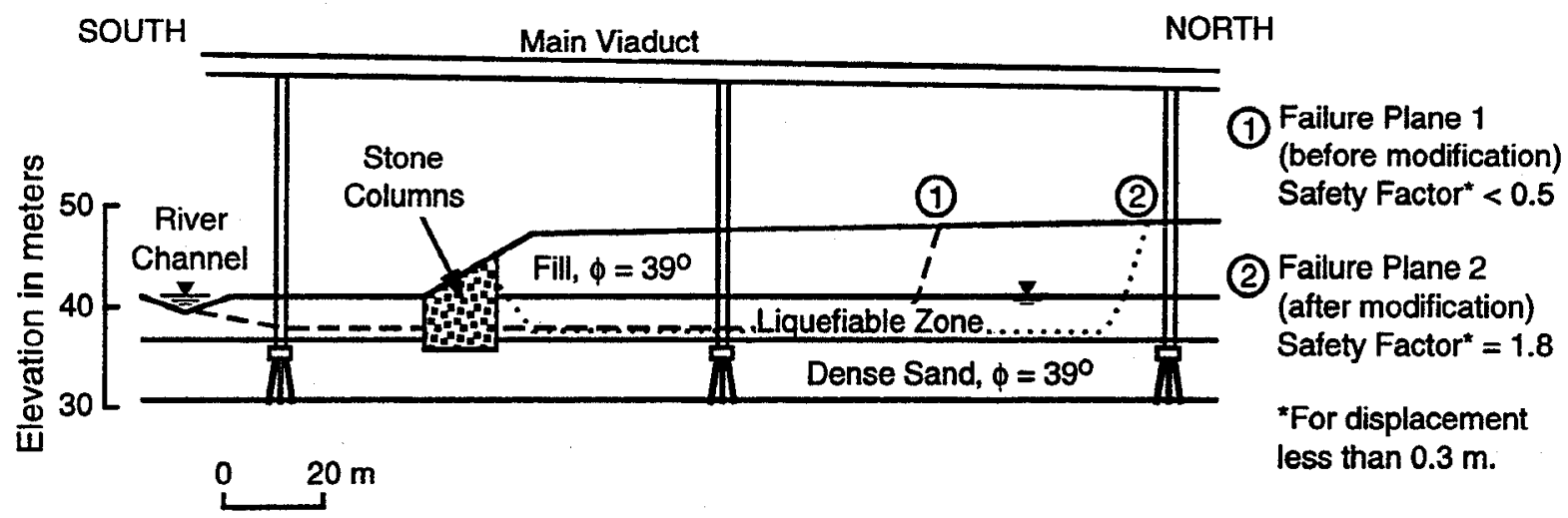

Fig. 3.5 - Cross Section of the I-805 Viaduct Near the San Diego River Showing the Generalized Soil and Underground Stone Column Buttress to Prevent LiquefactionInduced Lateral Spreading (after Jackura and Abghari, 1994).

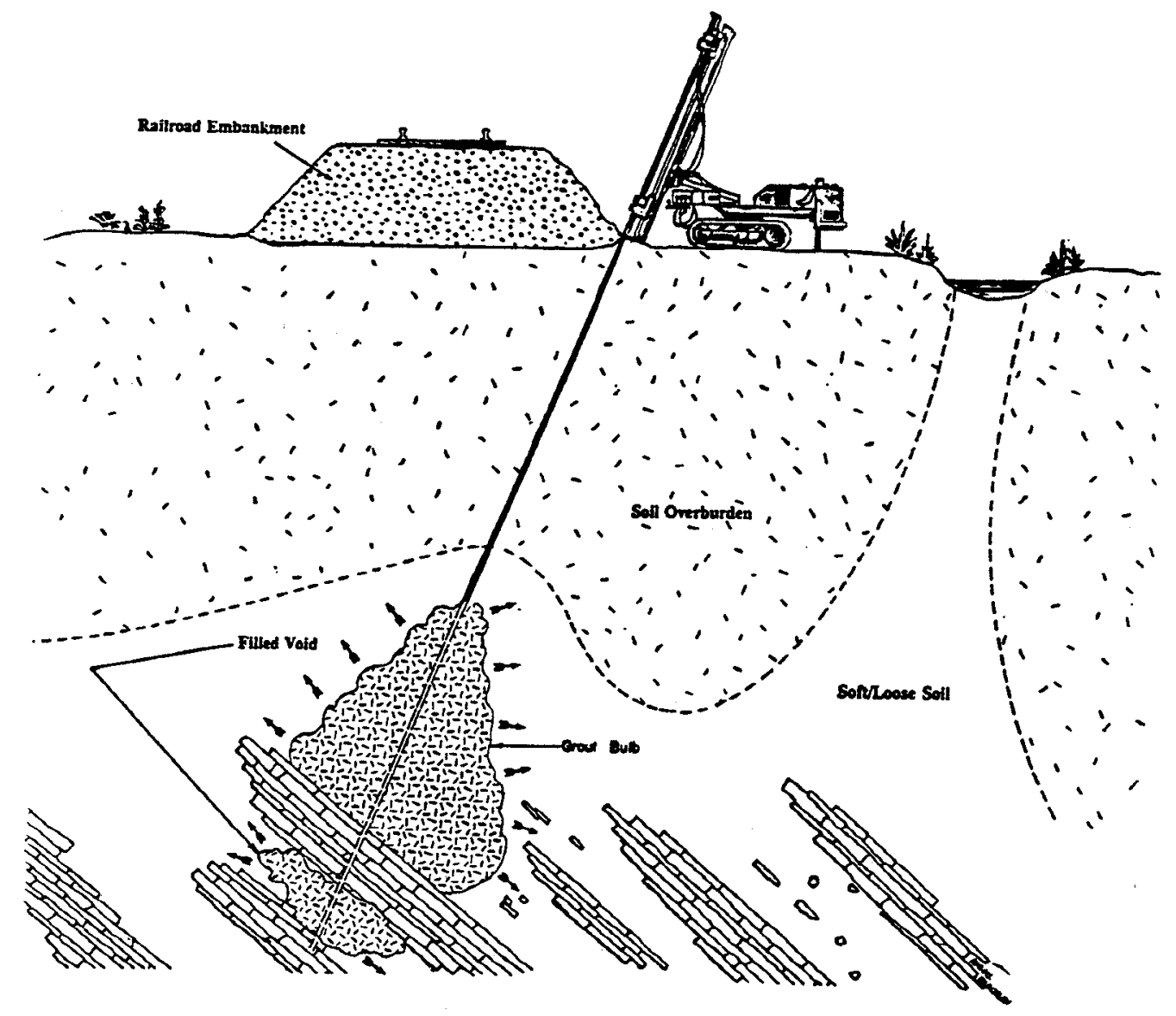

Fig. 3.6 - Remediation of Settled Rail Line in Sinkhole Area by Compaction Grouting (Brill and Hussin, 1992). 


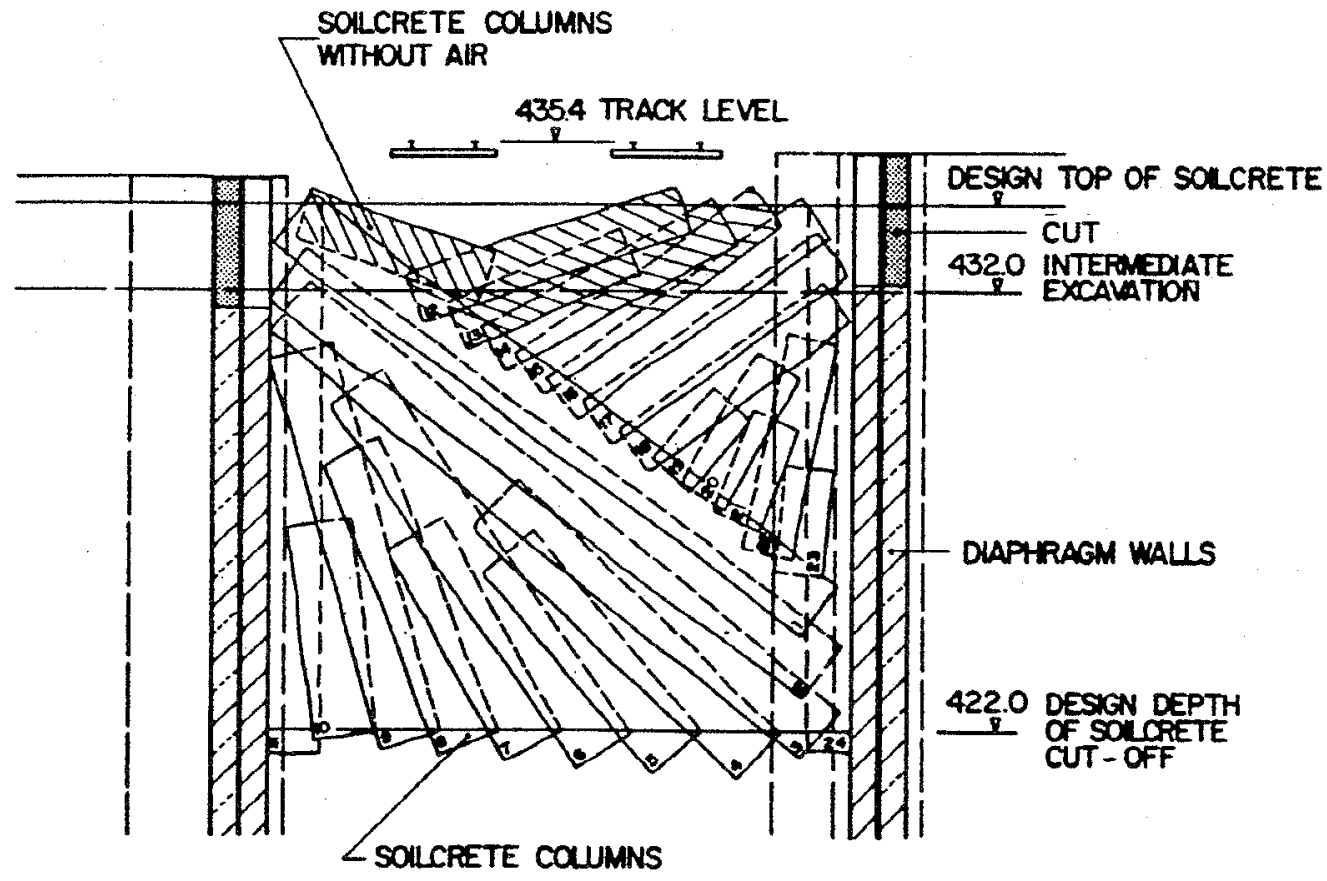

Fig. 3.7 - Excavation Support and Seepage Control by Jet Grouting Beneath Existing Rail Line (Steiner et al., 1992).

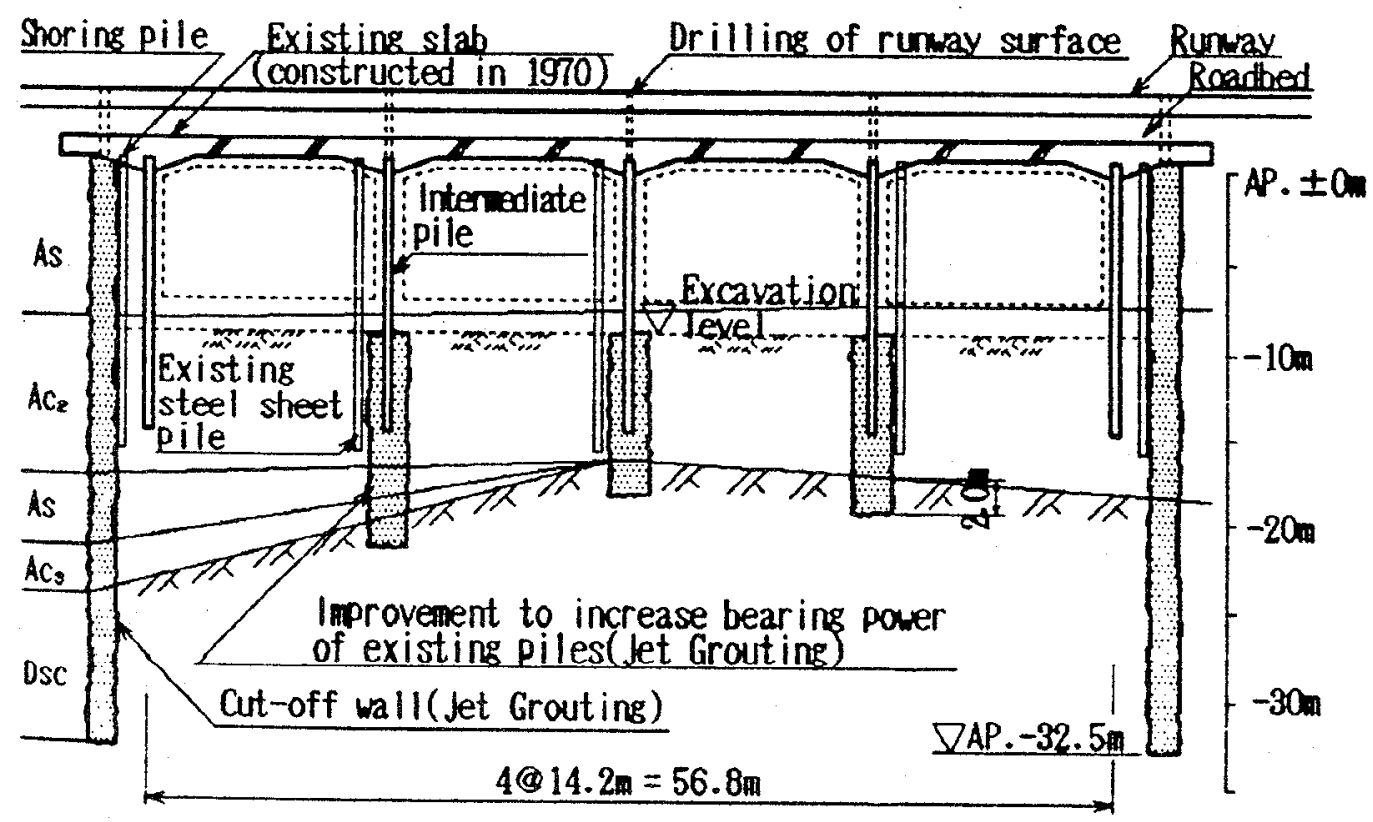

Fig. 3.8 - Excavation Support and Seepage Control by Jet Grouting Beneath Existing Airport Runway (Ichihashi et al., 1992). 


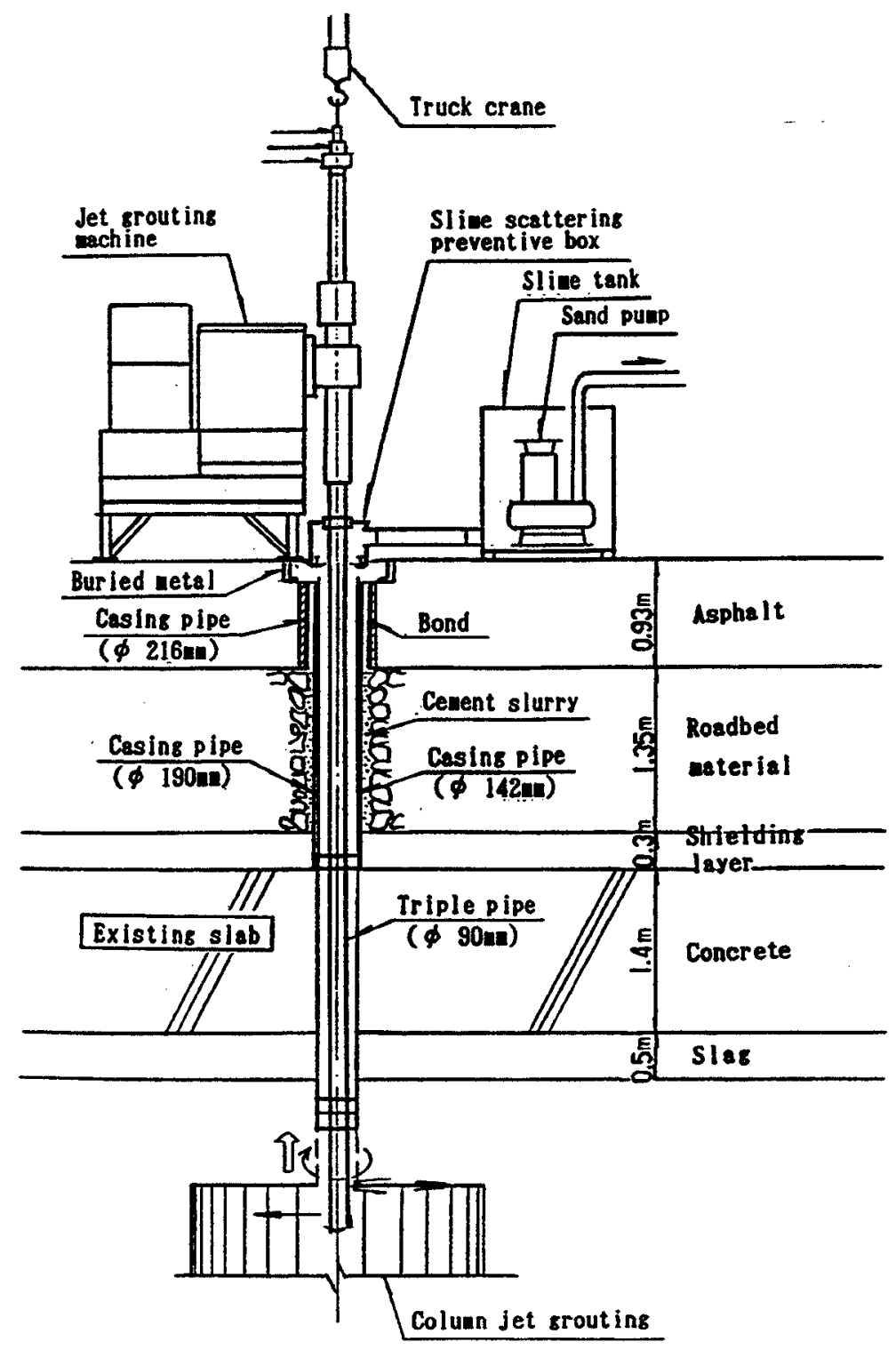

Fig. 3.9 - Configuration of Guide Casing and Waste Slurry Recovery System Used During Jet Grouting Beneath an Existing Airport Runway (Ichihashi et al., 1992). 


\section{CHAPTER 4}

\section{SUMMARY AND RECOMMENDATIONS}

\subsection{SUMMARY}

The report reviewed five low vibration techniques that have been used for ground improvement near existing structures. These five techniques are: compaction grouting, permeation grouting, jet grouting, in situ soil mixing, and drain pile. The factors which influence the effectiveness of each technique and thirteen available case studies of liquefaction remediation are reviewed in Chapter 2. Of these five techniques, only jet grouting and in situ soil mixing can treat all liquefiable soil types. Compaction grouting may be marginally effective in treating silts. Chemical grouts cannot permeate soils with more than about $25 \%$ fines (silt and clay). It seems that drains would be ineffective in ground with low permeability. Upon reviewing the available cases studies, one quickly becomes aware that very little has been reported on ground improvement near existing pipelines and other lifelines, let alone the actual seismic performance of sites treated by these techniques.

Six case studies of ground improvement near various lifelines are reviewed in Chapter 3. With great care and depending on their nature and condition, permeation and jet grouting could improve soil conditions immediately adjacent to lifelines. Compaction grouting could be applied beneath lifelines, but may not sufficiently compact soils immediately adjacent to them. The in situ soil mixing and drain pile techniques could possibly be effectively employed a short distance away (say 1 to $3 \mathrm{~m}$ ). Other less expensive ground improvement techniques, such as vibro-replacement through pre-augered holes, could be used within about $1 \mathrm{~m}$ of many lifelines. A combination of techniques may provide the most cost-effective ground improvement solution.

\subsection{RECOMMENDATIONS FOR FUTURE STUDY}

The following recommendations are provided to identify areas that need further study.

1. Compile additional case studies of ground improvement near pipelines and other lifelines. These case studies should include detailed information about the condition of the lifeline, ground improvement procedures, verification techniques, and cost. 
2. Compile additional case studies documenting the performance of improved ground during strong earthquake shaking.

3. Perform laboratory and field investigations to determine how much ground improvement is needed to protect pipelines and other lifelines.

4. Develop less expensive ground improvement techniques, since all the low vibration techniques reviewed are expensive to conduct. 


\section{APPENDIX A}

\section{REFERENCES}

Applied Technology Council, ATC-25 (1991). "Seismic Vulnerability and Impact of Disruption of Lifelines in the Conterminous United States," Earthquake Hazard Reduction Series 58, Federal Emergency Management Agency, Washington, D.C., 439 p.

Babasaki, R., Suzuki, K., Saitoh, S., Suzuki, Y., and Tokitoh, K. (1991). "Construction and Testing of Deep Foundation Improvement Using the Deep Cement Mixing Method," Deep Foundation Improvements: Design. Construction, and Testing, ASTM STP 1089, M.I. Esrig and R.C. Bachus, Eds., American Society for Testing and Materials, Philadelphia, NJ, pp. 3246.

Baez, J.I. (1995). Personal communication.

Baez, J.I., and Henry, J.F. (1993). Reduction of Liquefaction Potential by Compaction Grouting at Pinopolis West Dam, SC." Proceedings. Geotechnical Practice in Dam Rehabilitation: Geotechnical Special Publication No. 35, held in Raleigh, North Carolina, on 25-28 April, L.R. Anderson, Ed., ASCE, New York, NY, pp. 493-506.

Baker, W.H. (1982). "Planning and Performing Structural Chemical Grouting," Proceedings, Grouting in Geotechnical Engineering, held in New Orleans, Louisiana, on 10-12 February, W.H. Baker, Ed., ASCE, New York, NY, Vol. 1, pp. 515-539.

Barksdale, R.D. (1987). Application of the State of the Art of Stone Columns--Liquefaction, Local Bearing Failure, and Example Calculations: Technical Report REMR-GT-7, Department of the Army, U.S. Army Corps of Engineers, Washington, D.C.

Bell, A.L. (1993). "Jet Grouting," Ground Improvement, M.P. Moseley, Ed., CRC Press, Inc., Boca Raton, FL, pp. 149-174.

Brill, G.T., and Hussin, J.D. (1992). "The Use of Compaction Grouting to Remediate a Railroad Embankment in a Karst Environment," Proceedings. Twenty-Third Ohio River Valley Seminar--In Situ Soil Modification, held in Louisville, Kentucky, on 16 October.

Broomhead, D., and Jasperse, B.H. (1992). "Shallow Soil Mixing--A Case History," Proceedings, Grouting, Soil Improvement and Geosynthetics: Geotechnical Special Publication No. 30, held in New Orleans, Louisiana, on 25-28 February, R.H. Borden, R.D. Holtz and I. Juran, Eds., ASCE, New York, NY, Vol. 1, pp. 206-214. 
Chung et al. (1995). "The 1995 Hanshin-Awaji (Kobe) Earthquake: Performance of Structures, Lifelines, and Fire Protection Systems," R.M. Chung, Ed., U.S. Department of Commerce, National Institute of Standards and Technology, Gaithersburg, MD, in preparation.

Covil, C.S., and Skinner, A.E. (1994). "Jet Grouting--A Review of Some of the Operating Parameters that Form the Basis of the Jet Grouting Process," Proceedings, Grouting in the Ground, held in London, England, on 25-26 November 1992, A.L. Bell, Ed., Thomas Telford, London, pp. 605-629.

Darragh, R.B. and Shakal, A.F. (1991). "The Site Response of Two Rock and Soil Station Pairs to Strong and Weak Ground Motion," Bulletin of the Seismological Society of America, Vol. 81, No. 5, October, pp. 1885-1899.

Ford, D.B., and Bratton, G.N. (1991). "Preliminary Earthquake Mitigation Planning to Improve Watermain Performance in Vancouver, B.C.," Proceedings. Third U.S. Conference on Lifeline Earthquake Engineering: TCLEE Monograph No. 4, held in Los Angeles, California, on 22-23 August, M.A. Cassaro, Ed., ASCE, New York, NY, pp. 875-887.

Fujii, Y., Ohtomo, K., Arai, H., and Hasegawa, H. (1992). "The State of the Art in Mitigation of Liquefaction for Lifeline Facilities in Japan," Proceedings, Fourth Japan-U.S. Workshop on Earthquake Resistant Design of Lifeline Facilities and Countermeasures for Soil Liquefaction: Technical Report NCEER-92-0019, held in Honolulu, Hawaii, on 27-29 May, T.D. O'Rourke and M. Hamada, Eds., National Center for Earthquake Engineering Research, State University of New York at Buffalo, NY, pp. 889-909.

Gambin, M.P. (1991). "Lateral Static Densification at Monaco--Design, Construction, and Testing," Deep Foundation Improvements: Design. Construction, and Testing. ASTM STP 1089, M.I. Esrig and R.C. Bachus, Eds., American Society for Testing and Materials, Philadelphia, pp. 248-265.

Gazaway, H.N., and Jasperse, B.H. (1992). "Jet Grouting in Contaminated Soils," Proceedings, Grouting. Soil Improvement and Geosynthetics: Geotechnical Special Publication No. 30, held in New Orleans, Louisiana, on 25-28 February, R.H. Borden, R.D. Holtz and I. Juran, Eds., ASCE, New York, NY, Vol. 1, pp. 206-214.

Glaser, S.D., and Chung, R.M. (1995). "Use of Ground Improvement to Mitigate Liquefaction Potential for Lifelines," Proceedings, U.S.-Taiwan Geotechnical Collaboration Workshop, held in Taipei, Taiwan, on 9-11 January.

Glossop, R.G. (1961). "The Invention and Development of Injection Processes, Part II: 18501960," Geotechnique, Institution of Civil Engineers, London, Vol. XI, No. 4, pp. 255-279. 
Gould, J.P., Tamaro, G.J., and Powers, J.P. (1992). "Excavation and Support Systems in Urban Settings," Proceedings, Excavation and Support for the Urban Infrastructure: Geotechnical Special Publication No. 33, held in New York, New York, on 14-15 September, T.D. O'Rourke and A.G. Hobelman, Eds., ASCE, New York, NY, pp. 144-171.

Graf, E.D. (1992a). "Earthquake Support Grouting in Sands," Proceedings, Grouting, Soil Improvement, and Geosynthetics: Geotechnical Special Publication No. 30, held in New Orleans, Louisiana, on 25-28 February, R.H. Borden, R.D. Holtz and I. Juran, Eds., ASCE, New York, NY, Vol. 2, pp. 879-888.

Graf, E.D. (1992b). "Compaction Grouting, 1992," Proceedings, Grouting. Soil Improvement, and Geosynthetics: Geotechnical Special Publication No. 30, held in New Orleans, Louisiana, on 25-28 February, R.H. Borden, R.D. Holtz and I. Juran, Eds., ASCE, New York, NY, Vol. 1, pp. 275-287.

Graf, E.D. (1995). Personal communication.

Graf, E.D., and Zacher, E.G. (1979). "Sand to Sandstone: Foundation Strengthening with Chemical Grout," Civil Engineering, ASCE, New York, NY, January, pp. 67-69.

Greenwood, D.A. (1994). "Report on Session 1: Permeation Grouting," Proceedings, Grouting in the Ground, held in London, England, on 25-26 November 1992, A.L. Bell, Ed., Thomas Telford, London, pp. 71-90.

Hall, W.J., and O'Rourke, T.D. (1991). "Seismic Behavior and Vulnerability of Pipelines," Proceedings. Third U.S. Conference on Lifeline Earthquake Engineering: TCLEE Monograph No. 4, held in Los Angeles, California, on 22-23 August, M.A. Cassaro, Ed., ASCE, New York, NY, pp. 761-773.

Hamada, M., and O'Rourke, T.D., Eds. (1992). Case Studies of Liquefaction and Lifeline Performance During Past Earthquakes: Technical Report NCEER-92-0001, Vol. 1, National Center for Earthquake Engineering Research, State University of New York at Buffalo, NY.

Hayden, P.F., and Baez, J.I. (1994). "State of Practice for Liquefaction Mitigation in North America," Proceedings, International Workshop on Remedial Treatment of Liquefiable Soils, held in Tsukuba Science City, Japan, on 4-6 July.

Hausmann, M.R. (1990). Engineering Principles of Ground Modification, McGraw-Hill, $632 \mathrm{p}$.

Hussin, J.D., and Ali, Syed (1987). "Soil Improvement at the Trident Submarine Facility," Proceedings, Soil Improvement--A Ten Year Update: Geotechnical Special Publication No. 12, held in Atlantic City, New Jersey, on 28 April, J.P. Welsh, Ed., ASCE, New York, NY, pp. 215-231. 
Iai, S., Matsunaga, Y., Morita, T., and Sakurai, H. (1994a). "Effectiveness of Measures Against Liquefaction Confirmed at a Recent Earthquake--A Case History During the 1993 Kushiro-Oki Earthquake, Proceedings, 26th Joint Meeting of United States-Japan Panel on Wind and Seismic Effects: NIST SP 871, held in Gaithersburg, Maryland, on 17-20 May, N. Raufaste, Ed., U.S. Department of Commerce, National Institute of Standards and Technology, Gaithersburg, MD, pp. 213-325.

Iai, S., Matsunaga, Y., Morita, T., Miyata, M., Sakurai, H., Oishi, H., Ogura, H., Ando, Y., Tanaka, Y., and Kato, M. (1994b). "Effects of Remedial Measures Against Liquefaction at 1993 Kushiro-Oki Earthquake," Proceedings. Fifth Japan-U.S. Workshop on Earthquake Resistant Design of Lifeline Facilities and Countermeasures Against Soil Liquefaction: Technical Report NCEER-94-0026, held in Snowbird, Utah, on 29 September-1 October, T.D. O'Rourke and M. Hamada, Eds., National Center for Earthquake Engineering Research, State University of New York at Buffalo, NY, pp. 135-152.

Ichihashi, Y., Shibazaki, M., Hiroaki, K., Iji, M., and Mori, A. (1992). "Jet Grouting in Airport Construction," Proceedings. Grouting, Soil Improvement and Geosynthetics. Geotechnical Special Publication No. 30, held in New Orleans, Louisiana, on 25-28 February, R.H. Borden, R.D. Holtz and I. Juran, Eds., ASCE, New York, NY, Vol. 1, pp. 182-193.

Ishihara, K., Kawase, Y., and Nakajima, M (1980). "Liquefaction Characteristics of Sand Deposits at an Oil Tank Site during the 1978 Miyagiken-Oki Earthquake," Soils and Foundation, Japanese Society of Soil Mechanics and Foundation Engineering, Vol. 20, No. 2, pp. $97-111$.

Jackura, K., and Abghari, A. (1994). "Mitigation of Liquefaction Hazards at Three California Bridge Sites," Proceedings, Fifth Japan-U.S. Workshop on Earthquake Resistant Design of Lifeline Facilities and Countermeasures Against Soil Liquefaction: Technical Report NCEER94-0026, held in Snowbird, Utah, on 29 September-1 October, T.D. O'Rourke and M. Hamada, Eds., National Center for Earthquake Engineering Research, State University of New York at Buffalo, NY, pp. 495-513.

JSSMFE (1995). Remedial Measure Against Soil Liquefaction--From Investigation and Design to Implementation, Japanese Society for Soil Mechanics and Foundation Engineering (in Japanese; translation into English in progress).

Karol, R.H. (1982). "Chemical Grouts and Their Properties," Proceedings. Grouting in Geotechnical Engineering, held in New Orleans, Louisiana, on 10-12 February, W.H. Baker, Ed., ASCE, New York, NY, Vol. 1, pp. 359-377.

Keller, T.O., Castro, G., and Rogers, J.H. (1987). "Steel Creek Dam Foundation Densification," Proceedings, Soil Improvement--A Ten Year Update: Geotechnical Special Publication No. 12, held in Atlantic City, New Jersey, on 28 April, J.P. Welsh, Ed., ASCE, New York, NY, pp. 136-165. 
Koga, Y., Matsuo, O., and Koseki, J. (1993). "Studies at PWRI on Mitigation Works Against Liquefaction of Sandy Ground," Proceedings, 25th Joint Meeting of the United States-Japan Panel on Wind and Seismic Effects: Technical Memorandum of PWRI No. 3217, held in Tsukuba, Japan, on 17-20 May, Public Works Research Institute, Tsukuba, Japan, pp. 381-388.

Kramer, S.L., and Holtz, R.D. (1991). NSF Workshop, Soil Improvement and Foundation Remediation with Emphasis on Seismic Hazards, held in Seattle, Washington, on 19-21 August, National Science Foundation, Washington, D.C., 106 p.

Ledbetter, R.H. (1985). Improvement of Liquefiable Foundation Conditions Beneath Existing Structures: Technical Report REMR-GT-2, Department of the Army, U.S. Army Corps of Engineers, Washington, D.C., 51 p.

Liao, H.J., Kao, T.C., Chen, M.S., and Wu, Z.C. (1994). "Grouting for Retaining Wall Movement Control of a Deep Excavation in Soft Clay," Proceedings, Grouting in the Ground, held in London, England, on 25-26 November 1992, A.L. Bell, Ed., Thomas Telford, London, pp. $403-416$.

Littlejohn, G.S. (1993). "Chemical Grouting," Ground Improvement, M.P. Moseley, Ed., CRC Press, Inc., Boca Raton, FL, pp. 100-130.

Matso (1995). "Lessons From Kobe," Civil Engineering, ASCE, New York, NY, April, p. 44.

Mitchell, J.K., and Wentz, F.J., Jr. (1991). Performance of Improved Ground During the Loma Prieta Earthquake: Report No. UCB/EERC-91/12, Earthquake Engineering Research Center, University of California at Berkeley, CA, 93 p.

National Research Council (1985). Liquefaction of Soils During Earthquakes, National Academy Press, Washington, D.C., 240 p.

Oishi, H., and Tanaka, Y. (1994). "Densification of Surrounding Soils Due to Gravel Drain Construction," Proceedings, Fourth Japan-U.S. Workshop on Earthquake Resistant Design of Lifeline Facilities and Countermeasures for Soil Liquefaction: Technical Report NCEER-92$\underline{0019}$, held in Honolulu, T.D. O'Rourke and M. Hamada, Eds., National Center for Earthquake Engineering Research, State University of New York at Buffalo, NY, Vol. 2, pp. 929-942.

Ono, Y., Ito, K., Nakajima, Y., and Oishi, H. (1991). "Efficient Installation of Gravel Drains," Proceedings, Second International Conference on Recent Advances in Geotechnical Earthquake Engineering and Soil Dynamics, held in St. Louis, Missouri, on 11-15 March, S. Parkash, Ed., University of Missouri-Rolla, MO, Vol. 1, pp. 437-444.

Onque, A. (1988). "Diagrams Considering Well Resistance for Designing Spacing Ratio of Gravel Drains," Soils and Foundations, Japanese Society of Soii Mechanics and Foundation Engineering, Vol. 28, No. 3, September, pp. 160-168. 
O'Rourke, T.D., and Jones, C.J.F.P. (1990). "Overview of Earth Retention Systems: 19701990," Proceedings. Design and Performance of Earth Retaining Structures: Geotechnical Special Publication No. 25, held in Ithaca, New York, P.C. Lambe and L.A. Hanson, Eds., ASCE, New York, NY, pp. 22-51.

O'Rourke, T.D., and Hamada, M., Eds. (1992). Case Studies of Liquefaction and Lifeline Performance During Past Earthquakes: Technical Report NCEER-92-0002. Vol. 2, National Center for Earthquake Engineering Research, State University of New York at Buffalo, NY.

O'Rourke, T.D., and Pease, J.W. (1992). "Large Ground Deformations and Their Effect on Lifeline Facilities: 1989 Loma Prieta Earthquake," Case Studies of Liquefaction and Lifeline Performance During Past Earthquakes: Technical Report NCEER-92-0002. Vol. 2, T.D. O'Rourke and M. Hamada, Eds., National Center for Earthquake Engineering Research, State University of New York at Buffalo, NY.

O'Rourke, T.D., and Palmer, M.C. (1994). Feasibility Study of Replacement Procedures and Earthquake Performance Related to Gas Transmission Pipelines: Technical Report NCEER94-0012. National Center for Earthquake Engineering Research, State University of New York at Buffalo, NY.

Perez, J.Y., Davidson, R.R., and Lacroiz, Y. (1982). "Lock and Dam No. 26 Chemical Grouting Test Program," Geotechnique, Institution of Civil Engineers, London, Vol. 32, No. 3, pp. 217-233.

Rubright, R., and Welsh, J. (1993). "Compaction Grouting," Ground Improvement, M.P. Moseley, Ed., CRC Press, Inc., Boca Raton, FL, pp. 131-148.

Ryan, C.R., and Jasperse, B.H. (1989). "Deep Soil Mixing at the Jackson Lake Dam," Proceedings. Foundation Engineering: Current Principles and Practices, held in Evanston, Illinois, on 25-29 June, F.H. Kulhawy, Ed., ASCE, New York, NY, Vol. 1, pp. 354-367.

Salley, J.R., Foreman, B., Baker, W.H., and Henry, J.F. (1987). "Compaction Grouting Test Program--Pinopolis West Dam." Proceedings, Soil Improvement--A Ten Year Update: Geotechnical Special Publication No. 12, held in Atlantic City, New Jersey, on 28 April, J.P. Welsh, Ed., ASCE, New York, NY, pp. 245-269.

Sasaki, Y,, and Taniguchi, E. (1982). "Shaking Table Tests on Gravel Drains to Prevent Liquefaction of Sand Deposits," Soils and Foundations, Japanese Society of Soil Mechanics and Foundation Engineering, Vol. 22, No. 3, pp. 1-14.

Scherer, S.D., and Weiner, E. (1993). "Underpinning and Leveling Settled Pipes and Channel," Proceedings. Third International Conference on Case Histories in Geotechnical Engineering, held in St. Louis, Missouri, on 1-4 June, S. Prakash, Ed., University of Missouri-Rolla, MO, Vol. II, pp. 1183-1188. 
Schmertmann, J.H., and Henry, J.F. (1992). "A Design Theory for Compaction Grouting," Proceedings, Grouting. Soil Improvement and Geosynthetics, Geotechnical Special Publication No. 30, held in New Orleans, Louisiana, on 25-28 February, R.H. Borden, R.D. Holtz and I. Juran, Eds., ASCE, New York, NY, Vol. 1, pp. 215-228.

Seed, H.B., and Booker, J.R. (1977). "Stabilization of Potentially Liquefiable Sand Deposits Using Gravel Drains," Journal of the Geotechnical Engineering Division, ASCE, New York, NY, Vol. 103, No. GT7, July, pp. 757-768.

Steiner, W., Schneider, E., and Cartus, M. (1992). "Soilcrete Cut-Off Wall for Undercrossing a Busy Rail Line," Proceedings. Grouting. Soil Improvement and Geosynthetics: Geotechnical Special Publication No. 30, held in New Orleans, Louisiana, on 25-28 February, R.H. Borden, R.D. Holtz and I. Juran, Eds., ASCE, New York, NY, Vol. 1, pp. 384397.

Stroud, M.D. (1994). "Report on Sessions 5 and 6: Jet Grouting and Soil Mixing," Proceedings, Grouting in the Grouting, held in London, England, on 25-26 November 1992, A.L. Bell, Ed., Thomas Telford, London, pp. 539-560.

Taki, O., and Yang, D.S. (1991). "Soil-Cement Mixed Wall Technique," Proceedings. Geotechnical Engineering Congress 1991: Geotechnical Special Publication No. 27, held in Boulder, Colorado, on 10-12 June, F.G. McLean, D.A. Campbell and D.W. Harris, Eds., ASCE, New York, NY, Vol. 1, pp. 298-309.

Tsai, K.W., Chou, C.K., Chang, J.C., and Wang, W.H. (1993). "Jet Grouting to Reduce Liquefaction Potential," Proceedings. Third International Conference on Case Histories in Geotechnical Engineering, held in St. Louis, Missouri, on June 1-4, S. Prakash, Ed., University of Missouri-Rolla, MO, Vol. I, pp. 609-611.

Warner, J., Schmidt, N., Reed, J., Shepardson, D, Lamb, R., and Wong, S. (1992). "Recent Advances in Compaction Grouting Technology," Proceedings, Grouting. Soil Improvement, and Geosynthetics: Geotechnical Special Publication No. 30, held in New Orleans, Louisiana, on 25-26 February, R.H. Borden, R.D. Holtz and I. Juran, Eds., ASCE, New York, NY, Vol. 1, pp. 252-264.

Watanabe, T. (1966). "Damage to Oil Refinery Plants and a Building on Compacted Ground by the Niigata Earthquake and Their Restoration," Soils and Foundations, Japanese Society of Soil Mechanics and Foundation Engineering, Vol. 6, No. 2, pp. 86-99.

Welsh, J.P. (1992). "Grouting Techniques for Excavation Support," Proceedings, Excavation and Support for the Urban Infrastructure: Geotechnical Special Publication No. 33, T.D. O'Rourke and A.G. Hobelman, Eds., ASCE, New York, NY, pp. 240-261.

Welsh, J.P. (1995). Personal communication. 
Welsh, J.P., Andersen, R.D., Barksdale, R.D., Satyapriya, C.K., Tumay, M.T. and Wahls, H.E. (1987). "Densification," Proceedings, Soil Improvement--A Ten Year Update: Geotechnical Special Publication No. 12, held in Atlantic City, New Jersey, on 28 April, J.P. Welsh, Ed., ASCE, New York, NY, pp. 67-97.

Yashinsky, M. (1994). New Developments Related to Soil Liquefaction in Japan: Internal Report, Caltrans' Office of Earthquake Engineering, Sacramento, CA, 29 p.

Yasuda, S., Nagase, H., Kiku, H., and Uchida, Y. (1992). "Appropriate Countermeasures Against Permanent Ground Displacement Due to Liquefaction," Proceedings. Tenth World Conference on Earthquake Engineering, held in Madrid, Spain, on 19-24 July, Balkema, Rotterdam, Vol. 3, pp. 1471-1476. 